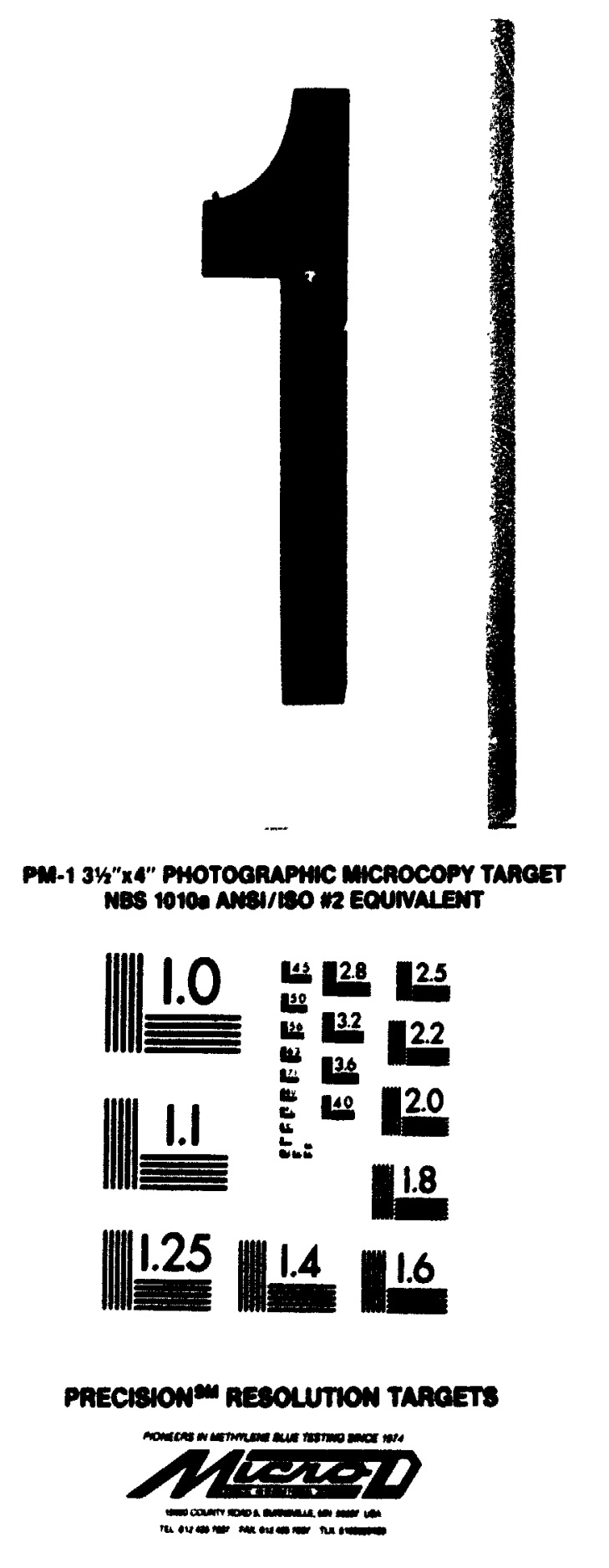


National Library

of Canada

Acquisitions and

Bibliograps ic Services Branch

395 Wellington Street

Ottawa, Ontano

KIA ON4
Bibliothèque nationale

du Canada

Direction des acquistions et

des services bibliographiques

395. rue Wellington

Otlawa (Ontario)

K:AON4
NOTICE

The quality of this microform is heavily dependent upon the quality of the original thesis submitted for microfilming. Every effort has been made to ensure the highest quality of reproduction possible.

If pages are missing, contact the university which granted the degree.

Some pages may have indistinct print especially if the original pages were typed with a poor typewriter ribbon or if the university sent us an inferior photocopy.

Reproduction in full or in part of this microform is governed by the Canadian Copyright Act, R.S.C. 1970, c. C-30, and subsequent amendments.
La qualité de cette microforme dépend grandement de la qualité de la thèse soumise au microfilmage. Nous avons tout fait pour assurer une qualité supérieure de reproduction.

S'il manque des pages, veuillez communiquer avec l'université qui a conféré le grade.

La qualité d'impression de certaines pages peut laisser à désirer, surtout si les pages originales ont été dactylographiées à l'aide d'un ruban usé ou si l'université nous a fait parvenir une photocopie de qualité intérieure.

La reproduction, même partielle, de cette microforme est soumise à la Loi canadienne sur le droit d'auteur, SRC 1970, c. C-30, et ses amendements subséquents. 


\title{
A RESEARCH FRAMEWORK TO UNDERSTAND THE CONTRIBUTION TO HUMAN RIGHTS ABUSE OF SOCIAL CLEAVAGE AND COMPETITION FOR SOCIAL CONTROL IN ETHNICALLY DIVIDED COUNTRIES:
}

\section{A SRI LANKAN ILLUSTRATION}

\author{
By \\ Marc Vincent, B.A. (Hons)
}

\begin{abstract}
A Thesis submitted to the Faculty of Graduate Studies and Research in partial fulfilment of the requirements for the degree of Master of Arts
\end{abstract}

Norman Paterson School of Intemational Affairs

Carleton University

Ottawa, Ontario

June 24, 1992

copyright

1992, Marc Vincent 
National Library

of Canada

Acquisitions and

Bibliographic Services Branch

395 Wellington Street

Ontawa. Ontario

KIA ON4
Bibliotheque nationale

du Canada

Direction des acquisitions et

des services bibliographiques

395, rue Wellington

Ontawa (Ontario)
The author has granted an irrevocable non-exclusive licence allowing the National Library of Canada to reproduce, loan, distribute or sell copies of his/her thesis by any means and in any form or format, making this thesis available to interested persons.
L'auteur a accordé une licence irrévocable et non exclusive permettant à la Bibliotheque nationale du Canada de reproduire, prêter, distribuer ou vendre des coples de sa thèse de quelque manière ot sous quelque forme que ce soit pour mettre des exemplaires de cette thèse à la disposition des personnes intéressées.

L'auteur conserve la propriété du droit d'auteur qui protège sa thèse. Ni la thèse ni des extraits substantiels de celle-ci ne doivent être imprimés ou autrement reproduits sans son autorisation. 
The undersigned recommend to the Faculty of Graduate Studies and Research acceptance of the the is

"A Research Framework to Understand the Contribution to Human Rights Abuse of Social Cleavage and Competition for Social Control in Ethnically Divided Countries:

\section{A Sri Lankan Illustration"}

Submitted by Marc Vincent, B.A. (Hons) in partial fulfilment of the requirements for the degree of Master of Arts.

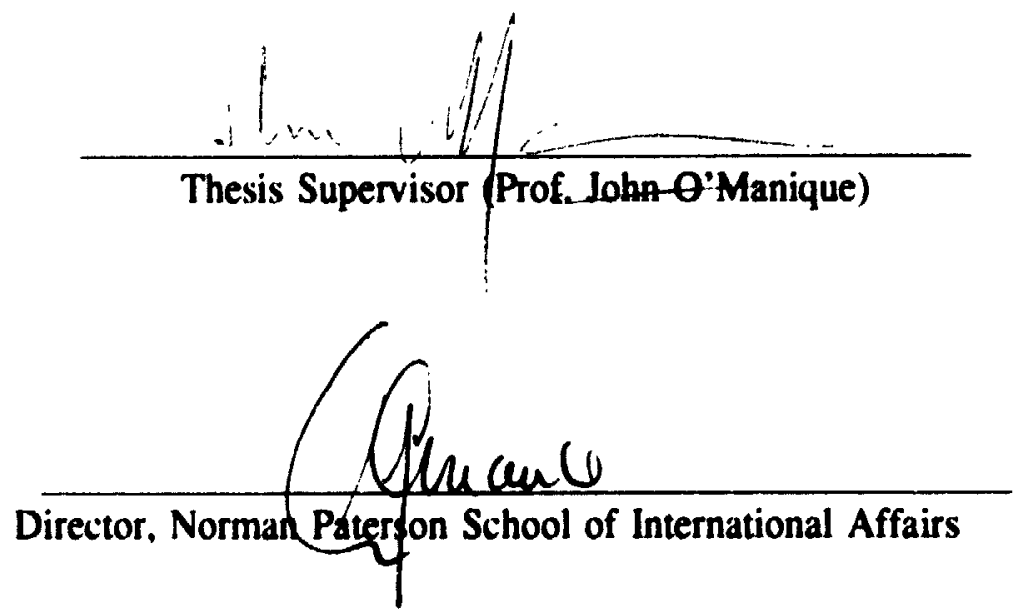

\footnotetext{
Carleton University

July 1,1992
} 


\begin{abstract}
ABSTRAC'T
An argument is advanced that political systems can be viewed as a melange of social organizations--conceiving the state as one organization among many, all competing for wider measures of control and influence. As competition and conflict excalates through four stages so too can abuse of human rights. The fourth and final stage exhibits widespread violence accompanied by gross and systematic abuse of human rights. The link between human rights abuse and competition over social control is at three different levels: 1) Discrimination and abuse of civil and political rights and socio-economic and cultural rights occurs as state leaders attempt to garner or recover social control: 2) Abuse of civil rights by mobilized, militant social groups, equally eager to gain social control and 3) Abuse by mid-level bureaucrats and community-level "strong-men."
\end{abstract}


To Jessie, for her inspiration and patience. 
INTRODUCTION

SECTION ONE: A RESEARCH FRAMEWORK

CHAPTER ONE: A CONCEPTUAL FRAMEWORK OF STATE AND SOCIETY RELATIONS

Part I: $\quad$ Social Formations and Ethnicity.

Part II: The Role of the State and Social

Formations.

CHAPTER TWO: HUMAN RIGHTS AND SOCIAL CONFLICT

Part I: $\quad$ Towards a Definition of Human Rights.

Part 1l: $\quad$ Escalation of Human Rights Abuse.

CHAPTER THREE: CAUSES AND MOTIVATIONS

OF HUMAN RIGHTS ABUSE

Part 1: Theories of State Terrorism. 46

Part II: $\quad$ Applying the Notion of Social Control. 55

Part III: Arriving At Some General Relationships. 59

\section{SECTION TWO: A SRI LANKAN ILLUSTRATION}

CHAPTER FOUR: SRI LANKA, 1948 - 1977

Part I: Introduction $\quad 64$

Part II: $\quad$ Historical Background and Early

Communal Relations.

Part III: Preindependence and Independence,

Stage One. 
Part IV: $\quad$ Linguistic Nationalism, 1956-1965.

Stage Two.

Part V: $\quad$ UNP Reconciliation, 1965-1970. An Attempt to Return to Stage One.

86

Part VI: $\quad$ Systemic Discrimination, Worsening Human Rights Abuse and the Emergence of Armed Opposition, 1970-1977. Stage Three.

CHAPTER FIVE: ESCALATION TO STAGE FOUR, $1977.19 \times 3$

Part I: $\quad$ The Return of the UNP and Failed Attempts At Reconciliation, 1977-1983.

Part II: $\quad$ The July 1983 Riots.

CONCLUSION: HUMAN RIGHTS ABUSE IN SRI LANKA AND THE STRUGGLE FOR SOCIAL CONTROL. 


\section{INTRODUCTION}

II 1979 as Tanzanian troops advanced deep into neightouring l'ganda. Idi Amin. the President of Uganda fled into exile. first to Libya. and eventual!y to Jedda in Saudi Arabia. The episode ended one of the most inhumane rules by terror in contemporary history and Idi Amin's name like many others--Adolf Hitler. Joseph Stalin. Pol Pot and Baby Do:--went down in history as the personification of gross human rights violations.

Amin, whose military rule of Uganda lasted for eight years, has been dexcribed with good reason by many as the "Hitler of Africa" (Mazrui \& Tidy. 1964). During his tenure he suspended all political activities and gave the army the power to arrest or showt any suspected opponents. In a short account Ali Mazrui and Michuel Tidy write: "In eight years, Amin's army and his state Research Bureau were responsible for the inurder of an uncountable number civilians and dissident soldiers, especially from among the intelligentsia of all ethnic communities. Estimates of the total number of dead range from a minimum of $1(K),(x)$ to a maximum of $3(x),(x)$." (Mazrui \& Tidy, 1984, p. 277)

In 1986, almost 10 years after the demise of Idi Amin. a London-based international NGO, International Alen, co-sponsored a seminar on internal conflict in Uganda. The basic premise of the conference was to look beyond Amin's pathological personality to internal conflict among different groups in society as one of the principal causal factors that contributed to Uganda's reign of terror and widespread gross human rights violations. In the end, conference participants recognized that internal conflict in Uganda had political, social and economic foundations exacerbated by regional imbalances and discriminatory deprivation which persisted and became the underlying 
source of grievance. Idi Amin's ascent to power and his subsequent reign of terror were seen as both a reflection of deep social cleavage in Uganda and an example of how one man was able to manipulate social decay for his own political advantage.

At the conclusion of the conference Martin Ennals, the director of International Alert wrote: "Finally, and not without its own significance, is the fact that the findings of the Conference in Uganda relate to similar problems in other conflict ridden countries where issues of ethnicity, language, education, decentralization and development are all recognized factors affecting peace or preventing dispute."(International Alert, 1987, p. 3)

On Dec. 10, 1948 the United Nations Declaration of Human Rights was passed. The Declaration itself was in large measure a reaction to the horrors of Dachua, Aushwtiz and Treblinka. Prior to World War II there had been attempts to develop international standards of human rights including agreements on the abolition of slavery and the International Labour Organization's Convention on Forced Labour. But determined attempts at codification of human rights really came after World War II when people and nations began to reflect on the causes of war. Two ideals surfaced; one was that world peace must be based on recognition and protection of human rights and the second was that never again could the world tum its back on the mass torture, murder and displacement of citizens by any government. (North/South Institute, 1988, p. 2)

Superseding the Declaration of Human Rights was the United Nations Charter which reflected the hopes and aspirations of the world community in the power of states to control their own destiny in the name of their citizens. In the period following World 
War II, former colonies and territories in Africa. Asia and Latin America gained independence. In the mind of politicians and academics the world over, the state was seen as the predominant unit in the intemational arena. Instruments like the Universal Declaration of Human Rights and the subsequent two Covenants reflected this view especially in regards to the role and duty of states. Unfortunately in the period since the independence of many countries it has become painfully obvious that statehorol and the appearance of government are not sufficient grounds for development, authority or sovereignty. Problems of governance aside, the focus and belief in the predominance of the state in political affairs and analysis led many authors in the field of human rights to narrow their inquiry to the role of the state in protecting and abiding by universal concepts of human rights. Even in the wake of the failure of many newly founded states to provide even the basic necessities of life and support of individual rights, human rights literature asserted that "the key question for social analysts of human rights,...is not why rights are violated but rather why are rights preserved." (Howard \& Donnelly, 1987, p.22)

Given this historical line of inquiry into human rights and assumptions surrounding the capabilities of the state, it is constructive to finally see organizations like International Alert focusing not solely on the instruments needed to protect human rights, nor the reasons why states preserve human rights, but why states and regimes, like Idi Amin's, abuse human rights. Some academics, such as Martin Rudner (1983), have made brief remarks about the causes of human rights abuse' but International Alen is among the

\footnotetext{
'Please see Martin Rudner's 1983 anticle on t : role of human rights condutiumality in Canadian Orfictual Development Assistance. In the article Rudner has categorived human rights abuse into four areas: A)Vulatums arising out of the crisis behaviour of govemments. Governments emersed in crisis, the argues, often tend w) subordinate economic and social concerns, including human rights. w) the neceds of upping with crisis. B)Viulatums
} 
very few organizations leading the way to understanding why? Two quotes from leading authors suggest both the enormity and urgency of this task.

One searches in vain through thousands of articles and bouks written by political scientists, political sociologists economists and anthropologists for references to the awful and bloody deeds of governments and for explanations of how and why these deeds are done...The only exception for this generalization is in the writing on totalitarianism, where it is clearly recognized that governments do use terror. However this writing makes totalitarianism into an aberration and by implication it presumes that governmental terror does not exist in other polities. (McCal. nant, 1984, p. (1)

If one considers to what extent and for how long a period grave and systematic human rights violations take place in the Third World the question of the general causes comes naturally. It is an amazing fact that only very little has been written on this topic. In most instances, the treatment of human rights themes does not go further than the presentation and discussion of norms and the description of the work of international organizations or the human rights situation in one country...Today there does not yet exist a research method for the origins of human rights violations in the Third World and consequently also no strategy for the removal of these origins. (Wolfgang Heinz, cited in Schmid, 1989, p. 5)

Alex P. Schmid. (1989) a Holland-based academic organizing an interdisciplinary research project on the causes of gross human rights violations ascribes the paucity of research in this area to a shortage of funds, the difficulty of field research, data problems, and the lack of a good theory or methodology. To Schmid's list, I add one reason of my own to explain the lack of research: human rights literature has for too long focused on the role of the state in protecting human rights without seriously considering the impact social cleavages and competition for power and resources among, for example, ethnically

arasing (wot of suxial patholkygy. The coming to power of psychopathic regimes such as Idi Amin is often accompanied hy cxploitation of kng standing traditional tensions in the community. C)Violations of human rights arising from Ithe iutronketion of certain devekopment policies. particularly discriminatory allocation of resources. Source: Rudner. M.. (ISW.3) Human Rights Comditimality and Intemational Development Cooperation. A study prepared for the Cankulian Int:matiomal Deveknpmeor Agency. January 1983. 
differentiated social groups have on the human rights record of states. The consequent foc :s on United Nations enforcement. international law or the necessity of stat: compliance has resulted in a dearth of research which examines how the dynamics of conflict and competition among social groups contributes to the abuse of human rights.

This thesis will attempt to address the lack of research int' the causes of human rights abuse through the development of a research framework and a test of some of its fundamental aspects within an illustrative study of Sri Lanka. Development of the framework and research agenda is the principal goal and its first test is to understand more about the factors that lead to human rights abuse within the context of a political system. The framework will not attempt to explain all causes of human rights abuse since it is far too early to make such a claim. I have chosen to begin by focusing on the state as a primary agent of human rigints abuse. ${ }^{2}$ This choice has meant that the types of human rights abuses described are primarily, although not exclusively, civi: and political rights. I do not assert that civil and political rights are more important but merely more common in the context I am examining. 'While the emphasis is on state abuse of civil and political rights, the framework also incorporates state abuse of social, cultural and economic rights and non-state abuse of civil and political rights. Eventually as the

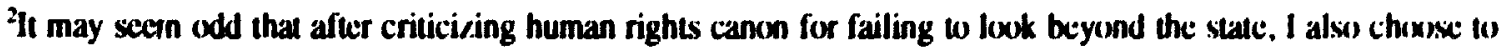
focus on the statc. Observation of human rights situations around the world suggest the state is a primary, if ner the primary, agent of abuse. It therefore makes logical sense that I begin examining the causess of humsan rights abuse by focusing on the principal abuser of human rights. Furthermore, it will become chviesus in the course of this propect that I am examining the state in a wider context than usual by treating it not as an autuncmous, self-regulating unit but as one social organization among many in society.

The working definition of human rights in this paper is actually very brcead. As I assen bere and in Chapter Three. the improvement of an individual and community's ability to succeessfully make a claim of humaun rights is the raison d'etre of development.
} 
framework is developed further, the elements contributing to social, cultural and economic rights abuse will be more elaborately addressed as well as non-state abuse of human rights, both civil and political rights and social, cultural and economic rights.

Ultimately by placing high priority on human rights this project also concerns itself with the wider debate to define what is meant by 'development.' I take the position, right from the start, that human rights are not merely supplements to development. Improving the acceptance and exercise of the full range of human rights, simply put, is development. This is not ideological naivete nor wishful thinking. Since the 1950's the international community's understanding of the 'development process' has matured and gone beyond blatantly equating development with economic growth. It is now becoming widely accepted that the exercise of human rights is a necessary component of the development process. For example, the United Nations Development Program (UNDP) 1991 Development Report defined the basic objective of development as "enlarging the range of people's choices," and stated:

Many policy makers frequently concentrate on just one dimension - income. But this concentration is at best an over simplification and at worst a gross distortion of reality...Men, women and children must be the centre of attention--with development woven around people, not people woven around development. Moreover, development must be participatory, and for this, people must have the opportunity to invest in the development of their capabilities - in their health, education and training. They must also have the opportunity to put their capabilities to use--to be fully involved in all aspects of life, to express themselves freely and creatively. (UNDP Report: 1991, p. 1)

As will be asserted in greater detail in Chapter Two, ensuring human development, individual choice and participation is the embodiment of human rights. By examining the pitfalls of national development, in terms of the dynamics of conflict and human rights 
abuse I hope to explore the reasons for human rights abuse and contribute to the growing body of development knowledge.

Furthermore. I also hope to contribute to the current dialogue within aid agencies on the best way to promote human rights. In fact early inspiration for this project came from attempting to grapple with the practical considerations of integrating the promotion of human rights into an aid program. Aid agencies, like academics, recognize that states everywhere abuse human rights but yet there is little evidence that aid officials have seriously tackled the question of cause. Indeed, the promotion of human rights within aid programs is itself a source of controversy. Those who oppose the use of aid programs to promote human rights though, are steadily losing ground as it becomes recognized that the protection of human rights is a necessary component of development. Others who oppose the promotion and protection of human rights beyond their own national boundaries and use the inviolability of state sovereignty as a justification for their position, are also facing sustained argument. The argument comes from proponents of a world public order who believe the individual, not the state, is increasingly becoming the subject of intemational law ard therefore human rights within one country is of international interest and consequence. ${ }^{4}$ Although I will not attempt to grapple with questions of aid and human rights in this project--translating the picture that will emerge from this project into programming and policy innovation will have to be the subject of another effort--ultimately accepting the central role of conflict in human rights abuse leads

'See 0'Manique. J.. (in press) Development, Human Rights and Law, Human Rights Quanterly, (August 1992) and Myres S. McDougal, Harold Lasswell and Lung-chu Chen, (1980) Human Righes and World Public Order. New Haven, Yale University Press. 
one to the conclusion that where possible conflict resolution or conflict management, that is searching for mechanisms and means to balance or resolve colliding interests, should be one of the guiding techniques for the United Nations, human rights activists and aid programs intent on promoting human rights.

This research then is an attempt to put the pieces of a puzzle together in the hope that it will improve our comprehension of human rights abuse in the developing world and begin to tackle the requirements for improvement. This project is largely a taxonomy of some elements and social relationships that lead to human rights abuse. Where possible I attempt to go beyond mere identification of these factors and begin, through the use of social control as an analytical tool, to discuss some of the linkages and relations between social cleavages, conflict and human rights abuse. The project is largely hypothetical and conceptual but it is a beginning. We start from the fundamental assumption that the root causes of human rights abuse must be studied within the context of conflict and competition in society. Issues of conflict and the reactive patterns of social groups and the state become the crucible from which human rights abuse emerges. To comprehend and appreciate the connections and structure among the components of society, including communal groups and the state, we start in Chapter One by building a theoretical framework looking at the various affiliations within society that we call ethnicity, class and ideology. Evidently in complex societies the lines between different affiliations may be difficult to locate. Groups can combine various affiliations or, in an act of political expediency, choose different affiliations at various times as rallying symbols and causes.

\footnotetext{
'Scc Danicl Bell's (1975) articke in Glazer N., \& Moynihan. D. P. (Eds) Ethnicity Theory and Experience. Cambridge M.A.. Harvand University Press for a discussion of macro and micro social units.
} 
Among the various groups of society is a perpetual state of competition and/or conflict to gain power and resources. Several ethnicity experts, as we shall see for example, have contended that it is economic competition over scarce resources that exacerbates and exaggerates differences between various affiliatory groups. Moreover, in the Third World. the main arena for this inquiry, many development theorists have also accepted that the process of social, economic and political change is itself ridden with conflict. The conflict occurs as the acceleration, or the attempt to accelerate, economic, social and political change intensifies existing relationships between groups in society by highlighting the issue of who benefits. (Miller, 1989)

Complicating the competition within society is the state." When it is strong and has a capacity to have wide ranging influence in society, the state ultimately decides who gets what. An ideal state would fairly and equitably manage the competition among groups. This though is often not the case. In some societies the state has assumed a partisan role in social conflict as elites use its apparatus to advance their own and often group or affilial interests. Under different conditions the state sometimes lacks the power or mechanisms to effectively manage competition in society and thus leaves social groups to determine among themselves the distribution of authority and wealth. The ability and record of the state's role in managing competition obviously depends on many variables such as its institutional structure, its representation of the broader community, its penetration of society and the resources available.

Once we combine the complexity of state relations with the inter- and intra-group

\footnotetext{
${ }^{6}$ I an using the state here in its widest possible definition to include hoth the administrative structures and instruments of power and those oxcupants who have the ability to dettermine the use of these instrumesnts.
} 
relations within society we begin to understand the dynamics of social conflict. Furthermore, as I hope to show, the escalation of conflict within a society bears direct relation to the level of human rights abuse thus, the closer we come to understanding secial conflict the closer we come to understanding the factors that lead to human rights abuse. It may be argued that a society where competition among social groups has been institutionalized, routinized and legalized by the state will have fewer cases of human rights abuse than a society which is experiencing protracted social conflict where human rights have been subordinated by either the state, or competing social groups, to the needs of fighting the conflict. In the latter case I will argue that human rights abuse themselves have become institutionalized and routinized.

Obviously we are dealing with complex situations which require an equally complex and dynamic conceptual framework. To avoid static, snapshot analysis, this framework will attempt to incorporate both the state and social groups within one conceptual picture. The intent is to create, as much as possible a dynamic model within which the changing patterns of relations can best be understood. Only in this way will we approach even a superficial understanding of the ingredients of human rights abuse and a framework that can be applied to different situations.

Apparent though in even this introductory explanation of the framework is the scope of dixciplines and research needed to understand all the components. I cannot at this stage fully explain all aspects of the problem. Consequently the first goal of this project is to sketch the broad context of human rights abuse by elaboration of the conceptual framework. Having completed this, the next task of this project is to illustrate the model 
through application to the case of Sri Lanka. Rather than deal with all communal components of society and potential cleavages I will for reasons of personal economy isolate and concentrate on only one--that of ethnic affiliation and cleavage. To further limit the inquiry of the Sri Lankan situation we will not spend much time examining preindependence competition between the Tamils and Sinhalese. Nor will we examine at length the individual level or anthropological, sociological reasons for ethnic affiliation in Sri Lanka. Instead we will concentrate on the solidification of ethnic identity, in terms of Sinhalese and Tamil nationalism, and the escalation of human rights abuse in the postindependence period up to and including the 1983 Colombo riots. In particular we are interested in three major questions. First, what role does competition for scucial control and political self-preservation or advancement among ethnic-base.J social organizations play in causing and initiating escalation. We will in Chapter One and Three define what we mean by ethnic organization, social control and conflict escalation. Second, we are concerned with whether the presence of political moderates slows down or retards the process of escalation. During conflict excalation social groups become polarized. Moderates can often be the "bridge" between iwc competing perspectives and groups. In the Sri Lankan case when we refer to moderates we are chiefly concerned with those who have an influence over public opinion, be it in the political realm or social realm. Finally, we are concerned with the question of what, as best as we are able to describe them, are some causal factors or relationships that lead to rights abuse: In other words who commits the abuse and why? It is hoped by focusing on these issues we may understand a part of the dynamics between state and society in terms of conflict and begin to measure the 
impact of conflict on human rights violations.

To sketch the broad context Chapter One will look at the question of ethnicity and ethnic conflict paying specific attention to defining ethnic organization and the dynamics of conflic! and competition among ethnic groups. Chapter One will also examine social conflict and attempt to conceptually position the state within the social fabric by explaining the analytical tool of social control. Chapter Two will address the issue of measurement of human rights abuse and its relationship to conflict. Chapter Three will deal with the theories of state terrorism in order to understand as best as possible within current bodies of research why states resort to violence and human rights abuse. Chapter Three will also expand on the framework with which we will examine the three questions as they apply to Sri Lanka. Chapter Four, on the basis of the framework, will examine the evidence of Sri Lanka up to 1977. Since the election of President Jayewardene is seen as the precursor to a new era in Sri Lankan politics, examination of his tenure will form the basis of Chapter Five. Finally in the conclusion we will examine the results and success of the framework to explain the Sri Lankan case and come back to some of the fundamental issues we have been discussing here. 


\section{CHAPTER ONE: A CONCEPTUAL FRAMEWORK OF STATE AND SOCIFTY}

\section{RELATIONS}

It must reiterated at the outset that the intent of this chapter is to clesurite a conceptual framework that links the concepts of social organization, the state and a scxial environment of competition and conflict into a coherent whole. By attempting to tie together so many broad issues it will be impossible to give the altention to each area of study that separately they all deserve. Moreover, developing a complete and fully argued conceptual framework which covers so many elements of a community's social fabric into one piece of research, let alone one chapter is not feasible. I have therefore tried to maintain a level of generality but at the same time break off manageable portions for further attention. The following is a guide. It cannot be treated as a testable or fully developed model but rather a first approximation that tentatively links the issues we must grapple with if we are to understand human rights abuse.

\section{Part I: Social Formations and Ethnicity}

Research into ethnicity, like human rights abuse, had generally excaped, until recently, the interest of many western political scientists. This oversight was largely the result of a political perception of the state and society that depicted ethnicity as a remnant of traditional culture quickly swept away in a country's drive for cultural and national integration. (Brown, 1989: Ra'anan, 1980: Essman, 1987) This popular view of ethnicity was most prevalent between 1950 and the 1970's when political science was dominated by the modernization theory. 
Even after the 70)'s when modernization theory was replaced by theories of political change, ethnicity was still considered by Marxists and Non Marxists alike as part of society's superstructure and largely irrelevant. (Brown, 1989, p. 2) Scholars like Uri Ra'anan, (198(1) contend that western social scientists have still yet to abandon some of their misconceptions regarding the role of ethnicity and identity in the developing world. Allegiance to a state, residence within a defined territory and a submission to state jurisdiction have been the hall marks of western concepts of national identity since the early works of political philosophy. However people in many developing countries have defined their national identity according to who they are, based on cultural, ethnic or religious affiliation. Thus, argues Raanan, the issue of ethnicity continues to be misunderstood by western scholars because they assume their concept of state and national identity have universal validity.

... what many western analysts simply do not seem to grasp is that their essentially territorial concept of nationality, according to which citizenship and loyalty to the nation and the state are treated as interchangeable terms may not be the accepted approach elsewhere and that both historically and at present, it has been and remains very much a minority view. (Ra'anan, 1980, p. 11)

In any case, ethnicity has only in the last two decades become recognized as significant to political analysis and the understanding of the relationship between state and socitity. While it has been studied more frequently and critically in the last few years there is still no consensus among social scientists on what encourages or by what criteria people form ethnic affiliations.

Clifford Geertz. in one of the early attempts to explain ethnic identification, defined it as "primordial attachments" that result from merely being born into certain 
religious, ethnic or linguistic associations. "These congruities of blood. speech and custom and so on are seen to have an ineffable and at times overpowering coerciveness in and of themselves." (Geertz. 1963. p. 1(19).

Other scholars have avoided emphasis on the subjective, psychological aspects of primordial attachment and converged on the organizational aspect of group affiliation that supplements one's identity at birth with the coercive attractiveness of identifying with a group because of the exigencies of life. Donald Horowitz in attempting to grapple with the competing theories of ethnic identification posits affinity, attachment and identification at birth and ascription, affiliation with a certain group for support. as poles of a continuum. "Many of the puzzles presented by ethnicity become much less confusing once we abandon the attempt to discover the vital essence of ethnicity and instead regard cthnic affiliations as being located along a continuum of ways in which people organize themselves. At one end, there is voluntary membership; at the other, membership given at birth." (Horowitz, 1985, p. 55)

Even among those who focus on the demands of ascription rather than the conditions of birth, there are differing arguments on why people choose group identity. Some stress the search for emotional security, others argue that the choice is made on rational grounds of utility in the demand for access to resources while still others assert individuals often have no choice in their group affiliation because of circumstances of life which limit their options. Okwudiba Nnoli (1978) in studying ethnicity in Nigeria emphasizes how group identity and ethnicity satisfies the needs of individuals, particularly in urban settings where the struggle for jobs and financial security is most intense. Within 
urban settings, old rural kinships ties, she states, are supplanted by urban networks based on ethnicity for support.

Proponents of some psychoanalytic models, for example, use clinical terminology by referring to processes of "externalization, projection and displacement." Speculating on the psychological process of identity formation, the psychoanalytical models describe a tendency within human development to identify with a social group while at the same time, through parental and peer influence, "transferring" undesired personal qualities to other individuals and groups. What occurs. they argue, is an intertwining of sense of self with belonging to a group. Ultimately the psychoanalytic model argues that individuals find identity within a group but the group finds identity by comparing itself to real and perceived enemies. As Vamik Volkan suggests, "when one ethnic group becomes the enemy of another, both are tied together through extemalization and projection. In such a case, the enemy's existence is its opponent's necessity." (Volkan, 1991, p. 87)7

David Brown (1989) argues that the arguments of the sociological or psychoanalytical model probably hold true in different circumstances such that affiliation which offers both emotional security and interest satisfaction and is based on a widely aciepted perception of social order would have a wide appeal. Brown therefore defines the ethnic group as a pseudo-kinship group which promises to provide emotional security and practical support. But. Brown adds, it is not the possession of common cultural attributes that generates communal loyalty but rather the attributes provide outward

\footnotetext{
Sex V.D. Volkan's (1991) anticke. The Psyctuoanalytic Aspects of Ethnic Conflicts, in J. Monteville. Confict and Pouxctmatking in Mullinthnic Scxicties. Lexington. Mass.. Lexington Bocks for a further discussion of the mycthrantalylic asprets of ethnicity.
} 
manifestations and symbols with which to sustain the belief in common kinship. (Brown. 1989. p. 7)

More significant for our conceptual framework is that Brown. Nnoli and others state that ethnic identity is based in large part on the level of conflict and competition in society. For example Brown argues,

...the kind of communal rivalries which develop and the choice of these groups of the myths and symbols of ethnicity will depend on the kind of threats to their emotional security and to their practical interests with which they are confronted by their political environment. If therefore we are to specify more clearly the process whereby ethnic groups are defined we must begin to explain the palterns of security threats and interest options which develop in soxiety. (Brown. 1989. p. 8)

The notion that ethnic groups may be defined according to the level of threat and competition often goes beyond the discussion of what Horowitz called the "essence" of ethnicity to the question of mobilization. Attempts to understand mobilization address themselves specifically to what precipitates collective action along ethnic lines. Arguing that ethnic groups may remain passive and unmobilized for long periods of time, Milton Essman (1991) attributes ethnic mobilization to two factors. The first and likely cause of mobilization, he states, is a serious and manifest threat to "vital interests or established expectations" of an ethnic community. The threat may target a group's political position. economic livelihood or neighbourhood security. He gives the example of the Malays who immediately mobilized when the British colonial authorities threatened to eliminate their "special position" as the indigenous natives of Malaysia and confer equal political rights and status to immigrant Chinese and Indians. The mobilization of one community may then trigger a countermobilization of another community which fears its interests may 
suffer in the newly competitive environment. (Essman, 1991, p. 54) The second cause. in the absence of threat is the potential for new political or economic opportunities vis-avis other groups if mobilization occurs.

Without necessarily accepting one particular model of ethnic identity it seems clear that threats and competition in society are instrumental in ethnic identity. To explain how threats and competition break out into violence however, we are faced with an incredibly diverse field of theories of which Essman's is only one.

Rodolfo Stavenhagen (1987) lists at least four different theories based on various definitions of ethnicity. One theory directly attributes ethnic conflict to colonialism. In the pre-colonial period ethnic groups in plural, multiethnic societies maintained a separate parallel existence. Often regional separation and geographic distance allowed different ethnic groups to avoid direct competition. With the advent of colonialism diverse groups were united by what Stavenhagen calls the "overarching integrating" political system of colonial authority. Within this context different groups vere forced by migration to urban centres, (Nnoli, 1978) or perhaps territorial decisions of the colonial authority into situations of conflict. Ethnic competition or conflict was thus a phenomenon initiated by ineyualities introduced by the colonial power but persisting after independence of the colony.

Primordial theories, focusing on the subjective aspects of ethnicity, hold that while ethnic conflict may be exacerbated by colonialism it is the primordial affiliation which creates a we/them viewpoint. Conflict among different groups is generally latent. The conflict turns from a latent condition to outright violence only when social norms that 
keep hostilities in check are ignorea. Ethnic conflict is thus considered an inheremt natural phenomenon restrained by social and institutional rules of behaviour.

The third group of theories identified by Stavenhagen is what he calls organizational theories and generally fall on the end of the continuum opposite to the primordial theories. These theories attribute ethnicity not to deeply ingrained attitudes but to a particular organization within which individuals choose to express and identify themselves and relate to others. Conflict then is seen in a local specific context arising out of idiosyncratic issues and dynamics.

Finally Stavenhagen identifies political power as the principal subject over which different ethnic groups struggle. Inter-ethnic politics, says Stavenhagen, is simply an instance of how politics in general is conducted within the polity. Ethnic conflict is thus considered a purely political struggle to be solved only by political means.

On inspection several of the theories evidently overlap and some are less adeyuate than others in explaining ethnic conflict. If one starts with agreement that ethnic affiliation is more than a theoretical construct but a social reality that combines aspects of wiscription and affiliation then the theory of conflict over political power is automatically ruled out since it presupposes ethnic identification to be a political instrument that can be used and or discarded at will. Since ethnic conflict and competition is more persistent than the political theory suggests it is more likely that political conflict may be symptomatic of ethnic conflict rather than an explanation of ethnic conflict.

While the primordial theories explain how one may be born into a collective identity, the theories fall short in explaining conflict. By attempting to explain ethnicity 
and social conflict as totally dependent on one's birth into a certain group, it avoids the nagging question of how social conditions strengthen ethnic identity and cause conflict. The weakness of the primordial theory of ethnicity thus undermines its attempt to provide a comprehensive explanation of ethnic conflict: Moreover by asserting an inherent tendency towards conflict it fails to differentiate precisely when conflict will take place and it assumes that the issues of conflict are of secondary importance. In the end the primordial theories tend to rely heavily on static variables and are consequently unsuitable for a dynamic model.

The combination of historical conditions such as colonialism and organizational theories appear to have more credence in both explaining ethnicity as a phenomenon and why the interests of groups may collide and escalate into conflict. But here again the organizational-type theory explains conflict according to specific circumstances and in doing so fails to provide a general framework with which to compare different examples of ethnic conflict.

Overall ethnic theories of conflict appears to suffer from three fundamental errors of analysis: one relates to the danger of employing arbitrary and absolute definitions in attempting to describe ethnicity: the second is the failure to understand the role of intragroup rivalry while the third is the equally treacherous mistake of underestimating the role of the state in attempting to explain social formations.

Paul Brass, (1985) in a discussion of ethnic and class formations defines ethnicity, like horowitz, as a changing phenomenon arranged along a continuum between primordial and interest group definitions, However unlike Horowitz, he specifically warns against the 
danger of using a definition that may be at one end or the other extreme of the continuum. Seeing ethnic groups as primordial in nature creates an unchanging. monolithic definition or what he disparagingly calls a "given." Conversely, defining ethnic groups as merely interest groups ignores the cultural, symbolic aspect of ethnic identificatiun. The problem, he notes, is that ethnic and Marxist theories of social arrangements often succumb to "objectifying" or "reifying" their definition of social formation--be it ethnic group or class--by seeing them as more permanent, coherent or fundamental then they may be. This is particularly true, he states, of primordialists. One consequence of reliance on "objective" or absolute definitions is "an inability to deal with, or even comprehend, let alone predict, the ebb and flow of ethnicity and nationalism among particular peoples at different times and the sometimes dramatic shifts in ethnic group identifications." (Brass, 1985, p. 31) It seems important, then if we are to take the advice of Brass to use a flexible definition that can explain the "ebb and flow" of ethnicity.

A second analytical error, often arising from the first, is ignoring the internal dynamics of ethnic groups and the struggle for control of the group.

The culture and boundaries of an ethnic group are nearly always problematic in one sense or another. Most important, the definition and articulation of the central values of the group and, consequently, decisions concerning which persons are rightfully members of the group are matters of frequent concern within it. That means issues of control over the community and its central values and symbolic expressions are also a matter of recurring concern.(Brass, 198., p. 31)

Thus although we will be focusing on intergroup rivalry and relations we must be careful not to overlook internal group dynamics.

Finally on the third matter, one common fault of all ethnic theories of conflict is 
the lack of interdixciplinary coordination and flexibility regarding the role of the state. By focusing on ethnic groups, ethnic frameworks tend to subordinate the state to secondary importance except in circumstances where one particular ethnic group has managed to gain control over the institutions of the state. Then, the state is seen as a means by which one group alters the dynamics of social competition by claiming greater legal authority and ability to use coercive means to either subordinate or eliminate other sources of power. The assertion cannot be disputed and is very important to understanding the role of the state in specific circumstances but clearly the relationship between states and ethnic groups is not quite so simple. Given the prominence in varying degrees of the state in all countries we cannot overlook its role. For this reason a more thorough and comprehensive conceptual framework is needed that combines social organizations, such as ethnicity and the state, into one framework if we are to explain social conflict. In this way, one can explain how social organizations and the state interact, with control of state apparatus, for example by a social group, as only one constellation among many in statesociety relations. Having dealt with the issue of ethnic identity, mobilization and conflict to the extent we can, we must now look at the other half of the equation that is the role of the state and its relationship with other social formations.

\section{Part II: The Role of the State and Social Formations}

Most current academic literature that examines the role of the state in the Third World has done so in an attempt to explain the process of political change. Early modernization theory, for example, saw the state as the organizing and implementing 
agency of political change which would drive a country towards development. As several critics have since pointed out modernization theory tended to view development as a linear, teleological concept that categorized so called non-developed societies as traditional and therefore struggling towards modernization. As Samuel Huntington (1971) has noted modernization and traditionalism were viewed as opposite poles of history. A country merely struggled to go from one end to the other, guided by the state. Furthermore, as Joel Migdal has noted, modernization theory was preoccupied with the effect of the centre on the periphery. There was little attempt to understand the periphery's effect on the centre or on itself.

Other theoretical constructs also failed to focus on both society and state. Dependency theory saw local elites primarily influenced not by society but by the centre countries in a world capitalist economy (Wallerstein, 1979) More recent studies of the state in the Third World have Inoked closely at the relationship between state and society but still have tended to view the state as an autonomous organization which "penetrated" society or "extracted" resources. Alternatively, other studies on the Third World have focused on the dynamics of social relations such as patron-client ties or the informal market but have viewed society as a separate entity from the state.

Interestingly Migdal (1988), who identifies and addresses these issues, attempts to explain why some states have a difficult time achieving control over their citizens. He develops a conception of the role of the state that transcends previous parochial views and fits in well with our understanding of social organization by depicting society as "a melange" of social organizations rather than the dichotomous structure used by many 
other theories of state. The image of a melange, he states, conveys two facets of society. First, the groups within society may be heterogeneous both in their membership and in the rules they apply to behaviour. Seconoly, he states social control is not totally within state control but may also be dispersed among social groups within society. (Migdal, 1988, p. 28)

Migdal's conception of social control is essential to our model and deserves elaboration. Theories of social control have a long history in sociology, psychology and political science. On a general level social control describes the extent an organization, or community, is able to control individual passions and inclinations. Since the advent of behaviouralism though, theories of social control have become more complex and deal with different mechanisms of control. In 1961, Amitai Etzioni described organizations that exercised social control through three means. The first mechanism was coercion based on the threat of sanctions, the second was utility which held out the promise of remuneration and the third was normative control which required gaining internalized commitments from individuals to behave and respond in certain ways. ${ }^{8}$ Migdal suggests social control is based on an organization's ability, be it the state or otherwise, to obtain compliance, participation and legitimation from its members. Compliance relates to the organization's ability to gain conformity among its members, while participation denotes the "repeated voluntary use of action" on behalf of, or in service of, the organization. Finally, and most importantly, legitimation is acceptance that the rules and myths of the organization are right and true. Thus asserts Migdal:

\footnotetext{
"Ste Lewis Coser's (1982) article. The Notion of Social Control in Sociological Theory in J. Gibbs. (Ed). Social Conmerol, Vicws from the Saxial Sciences. London, Sage Publications.
} 
State social control involves the successful subordination of people's own inclinations of social behaviour or behaviour sought by other social organizations in favour of the behaviour prescribed by state rules.(Migdal, 1988, p. 22)"

One of Migdal's theses is that in some societies the social organizations that make up society are in constant conflict with each other in proposing different "rules of the game." Conflict is then a result of different organizations attempting to achieve social control based on their fundamental conceptions of human behaviour and different perceptions of how society should be organized. Says Migdal, there can be no understanding of the state in the Third World without first comprehending the structure of society of which the state is only one part.

The starting point for analysis is the environment of conflict: there is a struggle between state leaders, who seek to mobilize people and resources and impose a single set of rules and other social organizations applying different rules in parts of the society . (Migdal, 1988, p. 261)

Migdal's view of the state is one organization among many in socicty but, he still accepts that the state is a special organization because of the Weberian notion of a monopoly over legitimate use of violence.

In short, following Max Weber, I |Migdal] use an ideal-type definition of the state: It is an organization, composed of numerous agencies led and coordinated by the state's leadership that has the ability or authority to make and implement the binding rules for all people as well as the parameters of rule making for other social organizations in a given territory, using force if necessary to have its way. (Migdal, 1988, p. 19)

While Migdal's definition of the state is useful it has to be elaborated in terms of its relationship with other organization, especially ethnic groups, to be useful for our

\footnotetext{
'At the individual level, social control relys on the ability of organirations wo provide what Migdal calls viable personal "survival strategies." Successful strategies answer the needs of an individual in terms of matcriad bernefits and personal identity. These stralcgies will be discussed more claboralcly in Chapter Three.
} 
framework. The state, within the melange described by Migdal, should also be viewed as both a resource--because of its monopoly over legitimate recourse to violence as well as its ability to distribute resources--and an organization attempting to exert control over society. While social organizations may struggle over social control of their membership they are also struggling over control of the state mechanisms and decision-making bodies in order to make use of its legitimacy. It is in this way the state also becomes a threat if its mechanisms are controlled by opposing social organizations. Overall, the concept of the state that I propose to use has three essential characteristics. Primarily it is an organizational structure that has a legal, legitimate recourse to violence; second, in the Neo-Marxist tradition, it is an arena of social conflict as well as a prize of conflict because of its legitimacy and ability to allocate resources; and thirdly it is not necessarily a cohesive unit because depending on the degree of success of various social organizations to control it institutions, it may be comprised of fractured cliques reflecting the organization of society as a whole. ${ }^{10}$

Having completed our examination of the state we can now begin to present the analytical definitions that make up this conceptual framework. Regardless of one's conception of ethnicity, historical evidence suggests they are definitely forms of social organization that have their own conceptions of how society should be organized. In this

\footnotetext{
"The statc of course must be "entrusted" by the population with the recourse to violence. Legitimate recourse in violence nemains legitimate only as long as the state itself remains legitimate. While the question of legitimacy remains upe'n to dehate and beyond the immediate scope of this project. Weber. for example, identifies three 'pure Iypes" of kegitimatc authority: Legal authority. based on the legality of normative nules and the right of those elevated (1) authurity under such nules: Traditional authority, based on the sanctity of traditions and the legitimay of the status of these cxercising power under them; and Charismatic authority, based on the exemplary character of an individual and the numauive pallems or order ordained hy him. Source: Weber. M. (1964) in T. Parsons, (Ed). The Theory of Scxial Order and Ecomomic Organization. Toronto. Collier-Macmillan Lid.
} 
research topic we have identified ethnicity as only one means of social organization even though we accept that there are other--usually interrelated--forms of social formation such as class and ideology. In the case of ethnicity individuals group together into social organizations for a variety of reasons which may be a combination of affiliation at birth. or for support in complex environment. If social groups are organized in vertical or horizontal fashion then individuals may be aligned into homogeneous groups. This depiction of society is based on Horowitz's ranked and unranked societies in which he differentiated between ethnic struggle and the coincidence of ethnic and class struggle. In ranked societies one ethnic group may be subordinate to another in terms of political power, wealth and social status; the system can thus be perceived as hierarchically organized. On the other hand, in unranked systems ethnic groups may be internally stratified but they constitute more or less autonomous systems arranged in parallel fashion.

Based on Horowitz I am proposing a conception of society where social organization can be depicted as somewhere between the poles of vertical organization along ethnic lines and horizontal organization based on a differentiation of status or wealth. An example of the latter would be a highly stratified society based on class. In the middle is non vertical social groupings which reflect social organization based on a variety of membership attributes and group heterogeneity. Conflict and competition between the groups would thus appear likely to increase as a society becomes more horizontally or vertically organized.

Presented with an image of plural societies in which individuals have organized 
into different groups, and choosing to abandon the dichotomous conception of the state, then society can be viewed as an organic whole with different components competing for social control. The state in the context of this framework, of course, possesses a legitimate recourse to force and as such it becomes a prize over which different social groups also fight for control. Based on this, and Migdal's model, we can assume that armed conflict within society is less likely to occur when the state is strong, controlled by a balance of forces and able to achieve a strong measure of social control. A strong measure of social control though depends on the nature of society. In the event that society is not vertically or horizontally arranged then the state may be controlled by a variety of forces and facing relatively weak social organizations. Under these circumstances it would be better able to achieve what we have called social control. Most important is the inclination that in a vertically or horizontally aligned societies social organizations are strong and may fight among themselves over the fundamental conceptions of social order. In this environment the state, although it has a monopoly of legitimate authority to use force, does not have a monopoly on social control and thus can lose control or fight to regain it if other organizations have successfully transferred control to themselves. Even when the state is controlled by one social group it would still attempt to either regain or extend social control over other opposing social organizations.

The model as presented has several advantages although conceptually it is extremely complicated. Primarily we have avoided dogmatic absolute definitions which increases flexibility. Secondly, we have combined ethnicity and state into one framework which makes it much more realistic therefore increasing its adaptability to different 
conditions. Sceptics may argue that I have tried to incorporate too many variables into one framework to be useful. To this I can only say the nature of the subject being discussed requires it.

Accepting that certain constellations of state and society may have a greater proclivity than others towards social conflict, what determines the outcome? Why do some societies with similar structural conditions degererate into violence whereas others do not? Since the late 6(0)'s there has been a mul itucie of explanations including theories of social conflict, ethnic conflict, terrorism, revolution. sisct terrorism and gencocide to name a few attempts at explanation. Given the great bulk of literature on this topic and the widely held confusion on the subject it would be impossible to attempt categorization of the theories without losing focus on the conceptual framework. Thus I propose at this stage we put these issues aside until the third chapter where we can discuss them more fully. 


\section{CHAYTER TWO: HUMAN RI(BHTS AND SOCIAL CONFLICT}

\section{Part 1: Tuwards a Definition of Human Rights}

The crucial step now is to incorporate human rights into the framework. Clearly, we must first define human rights if we are to agree on how to measure their violation. The exercise of human rights, is informed by morality and dependent on values, social beliefs and historical experience. While human rights cannot be divorced from morality, if one is to discuss violation of human rights, one has to start with a common foundation free, if at all possible, from culturally-laden perceptions. This is the importance of definition. It is my argument that all human rights discourse and agreement on what constitutes a violation of human rights has to be founded on a definition of universal inalienable human rights. If the definition used is based on universality and inalienability it precludes any justification of violation of some rights based on different values, cultural experience or national priority.

Not all authors accept a definition of universal human rights. Admantia Pollis and Peter Schwab, (1982) for example, argue that different definitions of rights have arisen because of unique national experiences. Thus the Third World conception of rights, according to the pair, is fundamentally different from the western liberal conception. By asserting that Third World conceptions of human rights tend to priorize social, cultural and economic rights while western conceptions tend accentuate civil and political rights the Pollis/ Schwab model encourages the debate between the relative merits of the two groups of rights. This argument has taken up the attention of many scholars but is 
essentially a diversion. If we accept that rights are dependent upon locial practice and national historical experience, no amount of arguing or debate is going to satisfy proponents that either civil/political or social/economic rights are more important because that would involve denying the validity of the proponents various social experiences.

The Pollis/Schwab model is essentially inductive. It takes reality and huilds a theoretical model. Unfortunately, the approach plants the seed of its own demise. Since there is no agreement on what constitutes human rights any discussion of violation can quickly become mired in arguments of priority. cultural domination and inter-conceptual conflict." Accepting the Pollis/Schwab model would ultimately invalidate any altempt to measure violations of human rights especially those which are most controversial. namely social, cultural and economic rights.

A case for universal rights which are fundamental and inalienable regardless of their application has been rooted in the west on the primacy of natural rights which in turn was based on conceptions of divine and natural law. The discourse however inevitably retreats to its liberal origins in Locke and Hobbes and concludes that civil and political rights are more fundamental.

John O'Manique (1990) in a rather unique argument has found one avenue of escape from this semantic circle by building a model of human rights based not on liberal, socialist or nationalist philosophy but, based on something that every person in the world

\footnotetext{
"The point bere is not wo deny that human rights acceptence. excrcise and violations are influ"snced by different cultures but rather the definition of human rights must be based on universality and itealicnability. In this way. we may accept that all women's rights are the same no matter what culture they may live in however, the successsul exercise and acceptance of some rights may be influenced by, for example, the religious interpretation of Istaen.
} 
has in common-their biological origins and their will to survive and develop. He argues that the human need for survival and development exists in all humans by virtue of their evolution. The expectation that they will demand what is necessary for survival and development therefore forms the foundation of a definition for universal and inalienable human rights. $0^{\prime}$ Manique sees humans forming a contract among members of a community who share the will to develop, who accept their interdependence and who see some form of duty or responsibility in order for all to develop. This sense of responsibility can be based on rational self interest to the extent that if a person needs others for development he or she must respect their claims to develop. O'Manique concludes:

Human rights in practice can be seen, therefore, as the human transcendent version of the universal prupensity to develop found in all organisms. This drive, both for the development of the individual and the community exists in a person simply beciause the person is alive; moral attitudes, systems, agreements, laws and states are its effects, not its causes. To this extent we conclude that human rights are inalienable and universal. (O'Manique, 1990, p. 482)

O'Manique sums up by stating that the implementation of rights will vary according to the different needs of humans at various stages of development and to the community's perception of what rights are necessary. Rights themselves therefore are absolute but their exercise is relative.

Pursuing this line of enquiry, $0^{\prime}$ Manique (in press) also argues for the growing internationalization of human rights. By internationalization I refer to the greater impact that demands for respect of human rights has in the intemational forum. By logical extension $O^{\circ}$ Manique argues that for individuals in the modern world the exercise of 
rights transcends national borders:

To maximize the chances that I will be able to exercise my rights. I want a say in the type of social order in my community. Were I alive in earlier simpler times, I might have been content to be an agent of social order only within my village. I now however, demand a say in the governing of my city, my province and country. The exercise of my rights, however, is becoming more and more dependent on events beyond even these borders. Now the world itself is the community which I want to influence.... My development is tied more and more to the development of the planet. (O'Manique, in press)

As $\mathrm{O}^{*}$ Manique notes this perception of internationalization of human rights coincides with the World Order legal theorists such as Wilfred Jenks. Myres McDougall and I larold Lasswell. As McDougall et al write.

The important fact is that peoples of the world, whatever their differences in cultural traditions and styles of justification, are today increasingly demanding the enhanced protection of all those basic rights, commonly characterized in empirical reference as those of human dignity, by the processes of law in all the different communities of which they are members, including especially the international or world community. (cited in $0^{\prime}$ Manique, in press)

Unlike the positivist Pollis and Schwab model, the evolutionary model assumes all rights are absolute. There is no distinction between the absolute rights of people in the socialist system, the Third World or the West. The model does accept that communities and individuals within these different regions may priorize the implementation agenda. of different rights.

Agreeing now on a definition of human rights in which we can measure violation what can be said about the violators themselves? If we take our definition of human rights, any individual or organization that deprives another of his or her rights can be guilty of human rights violation. But the state, unlike other individuals and organizations, 
can be accused of violating human rights on two levels. First, the state through its institutional agencies such as the police or army can directly violate an individual's human rights. On an indirect level, the state can also be accused of violating human rights if it does not maintain a social order that prevents other social organizations or individuals from violating human rights. Thus while we accept that individuals, organizations and states can violate human rights the emphasis, in this project, is on attempting to understand state abuse of human rights. The line of inquiry therefore necessitates greater detail in understanding the state's responsibilities. Ideally within the legal jurisdiction we call the nation state it is the state that has prime responsibility for ensuring human rights abuse does not occur through enforcement of the domestic legal framework which determines the interaction of individuals and groups. The legal framework thus becomes the manifestation of social order agreed upon by the community and enforced by the state's legitimate right to apply the framework through sanction and coercion. Accordingly, individuals and social groups are held accountable for their actions by the legal framework while the nation state is to be held accountable in ensuring the framework works justly and fairly by intenationin! human rights codes and, in a democratic system, by its citizens. This is the basis of civil and political rights. In the realm of social, economic and cultural rights, the state is equally responsible to protect an individual's ability to lead a dignified life by ensuring equal access to resources needed for development. Obviously some countries do not have the resources to allow for universal education. welfare and so forth. Are these states then guilty of human rights violations: The answer must be based on intent. If the state consciously removes or 
retards an individual or groups's ability to strive for achievement of social, cultural or economic rights then it is in violation of human rights norms because it has broken what liberal thinkers would call the social contract. In this fashion David Gillies (1990) has argued that because of the difficulties of assigning government culpability in violation of socio-economic rights it may be more appropriate to speak of "nonadherence" rather than violation. Either way, if the state intentionally refuses to abide by socio-economic human rights principles it must be considered a violation. One important caveat though: in reality there are situations where the state may be unable to fulfil its responsibility to protect the rights of its citizens because of the exigencies of development, international macroeconomic shifts or conflict. Unacceptable though the occasional lapses may be, we must pay more attention in this paper to persistent patterns of state abuse. An example of a persistent pattern would be a decision by the state elites to deprive over a period of time one social group's ability to pursue social and economic rights.

The next issue to sort out is of a "chicken and egg" nature. Are human rights abuses the cause of conflict or a symptom of conflict? If human rights violations are a symptom, are they a symptom of one particular type of conflict! Kumar Rupesinghe in a discussion of human rights and ethnic conflict argues that human rights are often at the centre of conflict. For example he states;

Ethnic conflicts generally involve a clash of interests or a struggle over rights: rights to land, education, to the use of language, to political representation, to freedom of religion, to the preservation of ethnic identity, to autonomy or self determination, and so forth. (Rupesinghe, 1988, p. 20)

On the other hand, he also states that, ethnic conflict unlike most forms of labour 
conflict, or non-violent political activities, which are regulated by law in democratic countries, ethnic conflict is not legally regulated, in fact not even legally recognized so that human rights may be the first casualty.

...most states are ill-equipped to deal with outbursts and may even deny its |ethnic conflict| existence. Consequently when governments act to deal with such conflict they sometimes adopt repressive measures against one or the other of the opposing ethnies. And when this occurs human rights abuse takes place. (Rupesinghe, 1988, p. 20)

Edward Azar's model of protracted social conflict also posits human rights abuse as both the cause and outcome of conflict. Azar argues it is the satisfaction of human needs that forms the nexus of dispute in protracted social conflicts. According to Azar, the focus of the protracted social conflicts is on

...religious, cultural or ethnic identity which in turn is dependent upon the satisfaction of basic needs such as those for security, communal recognition and distributive justice....More fundamentally most contemporary conflicts are about developmental needs expressed in terms of cultural values, human rights and security. As such they are not easily suppressed and continue to be pursued in the long term by all means available including the possible acquisition and use of destructive weapons. (Azar, 1990, p. 2)

Azar adds that it is not only the deprivation of human needs, expressed in terms of human rights, that generate and reinforce protracted social conflicts, but the most obvious consequence of these conflicts is further deterioration of physical security which exacerbates the initial conditions of insecurity through further loss of life and means of support.

Apart from physical deterioration, protracted social conflict institutionalizes underdevelopment through the destruction of physical and social infrastructures. Efforts to pursue systematic development planning are halted and discarded as excessive military expenditure absorbs scarce resources. A vicious cycle of 
underdevelopment and conflict deprives not only the victimized communities but also the dominant groups of the economic resources for satisfying basic social needs. (Azar, 1990, p. 16)

The dilemma of determining whether human rights violations are a cause of conflict or symptom is again the result of the broad nature of human rights definition. Competition for resources to produce what might broadly be called a dignified life or development often become the centre of dispute as both Azar and Rupesinghe suggest. Alternatively, in the process of disputing access to resources groups may rely on a variety of instruments ranging from violence and killing, to use of state institutions to deny the access of less powerful groups to resources; both constitute a violation of human rights. In the end it is impossible to dispute either approach so we must consider human rights abuse both as one of the principal causes of conflict and the first victim of conflict.

The final issue to contend with is the measurement of human rights abuse. This is decisive because we will be using the excalation of abuse as an element of our dependent variable. Michael Stohl, David Carleton, George Lopez and Stephen Samuels (1986) have argued that the systematic study of human rights violations have generally been impeded by the failure to develop a sound and accepted means of measurement. They point to several problems in developing a framework: the yuantity and yuality of information and sources are inconsistent, human rights abuse sometimes becomes an integral component of a political structure and consequently difficult to observe as a separate phenomenon. The nature of the state is also problematic. In stable and unstable regimes different parts of the state may have different objectives. The task of ascertaining culpability soon becomes formidable. One clue to overcoming this bstacle, suggested by 
Stohl et al., is in the attempts of superiors to regain control of their policies in the face of repressive activity that was not ordered. The longer a policy is allowed to exist the less we should believe the state is unwilling to have its agents or its self-professed agents to act in its name, say Stohl et al. To overcome the more general problems Siohl et al. suggest a multidimensional approach which we will use in our dependent variable to assess the quantity, kind and degree of violations. The first dimension, proposed by Stohl et al. is scope which measures the level of violations by asking what is being done to victims. The second is intensity which measures the frequency of occurrence in each of the various types of violations and finally range which accounts for the size of population targeted for human rights abuse and deals with question of whose rights are being violated.

\section{Part Il: Escalation of Human Rights Abuse}

Responding to the need for greater consistency and coherence in reporting and measuring human rights violations some human rights analysts have developed short lists of rights. Rhoda Howard and Jack Donnelly (1988) for example identify ten essential rights which act as proxies for almost all other rights. As the authors point out there are at least 6() rights identified by the two Covenants alone which makes the accumulation of data on possible abuses of all rights complicated and almost overwhelming. Using a short list not only simplifies the procedure but also makes effective assessment and measurement more consistent.

David Gillies (199(0) has also developed a framework of human rights assessment 
based on a hierarchy of rights with core rights as the principal focus and deserving primary attention from governments and monitoring agencies. Core rights include freedom from: extra-judicial killing, torture, arbitrary arrest, hunger and disirimination. Rule of law and independence of the judiciary qualify as the secondary level of rights while civil and political rights form the tertiary level of rights. He argues nondiscrimination is the " glue that binds together the disparate branches of the family of human rights." The principle of nondiscrimination, says Gillies, is embedded throughout the Declaration and Covenants and has a direct bearing on their implementation. By cutting across all other rights, nondiscrimination becomes a "supra-positive" right that has widespread international consensus. Up to this point we have studiously avoided a positivist approach to human rights and I am not at this point suggesting we change that approach. According to the definition we have developed human rights are universal and inalienable therefore a right of nondiscrimination is hardly needed. Introduction of Gillies' conception of nondiscrimination though is a means of assessing an individual or group's ability to claim or exercise their human rights. Evidently there are other means of assessment but given the climate of competition we have described among the state and social groups, discrimination may be the first indication of a change in the state's inclination to protect human rights. Despite the difficulties of forming assessment on the principle of nondiscrimination Gillies argues the challenge should be addressed since. "in many developing societies economic discrimination is often at the root of later ethnic conflict, political violence and severe abuses of nonderogable human rights." For our purpose of assessment, Gillies' formulation is most helpful especially when combined with a 
modified description of escalation provided by A.P. Schmid (1989). Schmid identifies four "contexts" of human rights abuse arguing that one must understand violations within as well as among different contexts.(Schmid, 1989, p. 17) Schmid does not elaborate on the contexts but I have modified the contexts to stages of escalation ranging from political competition and limited human rights abuse to civil war and gross abuse of human rights. In this way not only can we understand human rights abuse within different 'contexts' but also among different countries which have reached various levels of escalation. The thread that links different levels of escalation is based on Gillies' notion of discrimination and Migdal's maasurement of social control. ${ }^{12}$

Stage (One Political mode: Antagonism between communal groups is articulated in the process of politics at the level of state institutions. The scope, intensity and range of human rights violations is limited to the occasional violation of communal groups ability to claim both civil and political and socio-economic rights. At this stage communal groups have faith in political institutions to resolve issues of disagreement.

Stage Two Conflict mode: Antagonism cannot be managed in a cooperative manner or otherwise defused. The rivalling groups not only compete with each other but turn to obstruct, damage and harm each other's interests which is a violation of human rights. At this stage, the state's inability to limit tension is a indication of its weakening social

\footnotetext{
'While' I use sxial control in the formulation of the escalation model I have yet to elaborate on the implications of suxial comtrol to human rights abuse. This question will be addressed in the next chapter where we focus on the reasions fir texalation. The purposse of presenting an initial formulation at this point is to avoid overwhelming the reaker with $(1 x)$ much information at once.
} 
control and increasing dispersal of social control to competing social organizations. Frequently the loss of state social control is commensurate with its loss of neutrality in which it becomes an institutional weapon of one particular group and thus loses mrobilization capacity compared to other social organizations. In this scenario the state loses legitimacy in the eyes of certain groups and thus loses social control and mobilization by pursing systematically discriminatory policies. Accordingly in stage Iwo the scope and intensity of violations increase. The range of abuse also broadens beyond a limited segment of one social group to any members connected to the group.

Stage Three Rule Based violence and armed conflict: Modes of action are chosen by one or all parties that involve the measured use of violence against opponents in order to achieve their submission. The most relevant characteristic of this stage is the greater loss of social control by the state to such an extent that various social organizations have resorted to violence to implement their own visions of social control and order. The state thus resorts to greater use of violence to maintain order. At this point the human rights abuse can also be called state terrorism.

Stage Four Gross Human Rights Violation: Unlimited, unrestrained use of violence to injure the opponent in violation of a wide range of human rights norms. Included are deliberate and unrestrained attacks on members of civilian population and the creation of excessive suffering of persons who may be associated with opposing social groups. At this stage the scope and intensity of violations are extreme. The range has also broadened 
as armed opponents and suspected supporters suffer the same consequences. In stage four the state has completely lost all social control over other social organizations and over it's own $:$, lus. Some organizations are acting outside of state authority but at the same time "borrowing" a cause in the state's name. Each social organization has, or, is in the process of setting up it's vision of social order.

It must be noted that I have not attempted to link violation of specific rights with each stage of excalation. The violation of specific rights will depend on the circumstances and environment within each country and may involve different combinations of civil/political and socio-economic rights. It should also be noted that I have not yet addressed the issue of cause, in other words what pushes escalation from one stage to another. It is to that subject and a more in depth examination of social control that we now lurn.

Before moving on it is instructive to briefly review the course of discussion. In Chapter I we identified ethnic groups as a form of social organization in which members of society assemble. Among the various groups is a state of rivalry and tension in the competition for power and economic resources. Among the social groups is the state which itself must compete for social control. Unlike the other social groups it has a legal mandate to manage competition between social groups; this it does with varying degrees of suciess. In an ethnically cleaved society there may be a propensity for the state to come under control by one social group which, if it occurs, has a profound effect on competition among groups. These tendencies we will call the structural variables in the determination of a potentially human rights abusive social system. In this chapter we 
defined human rights as universal and inalienable and accepted that violations of human rights norms can be the result of actions of both state. social organizations and individuals. We have chosen at this point to concentrate on state violations accepting that their occurrence result from a confluence of state and social variables. Finally we also defined and constructed the means to measure our dependent variable through various stages of excalation. 


\section{CHAYTER THREE: CAUSES AND MOTIVATIONS OF HUMAN RIGHTS ABUSE}

With the aid of our conceptual framework, this chapter will now continue the discussion of social control and the escalation of human rights abuse in greater detail. The objective is to construct an analytical framework to determine what, during the phenomenon of conflict excalation, contributes to human rights abuse. It will be recalled from Chapter One that the model portrays the state as one organization among many in the melange that makes up society. Within this melange, social organizations, based for example on ethnic affiliation, and the state are each trying to establish a social order founded on what they consider to be fundamental values. The state may, according to the Weberian definition, have a legitimate recourse to coencion but by no means does it have a monopoly of social control.

In order to understand the dynamics of human rights abuse, we must therefore go beyond general structural characteristics of a potentially human rights abusive society to determine the contributing factors that precipitate human rights abuse. These factors can be broadly called social dispositional variables-in other words they are the factors that may transform a potentially abusive society into an abusive society. Social dispositional variables account for the acceptability or tendency among state leaders, bureaucratic administrators, or what Migdal called 'strongmen,'--the leaders of other social organizations--to choose a repressive course of action that is human rights abusive. We are not assuming that state leaders or anyone else chooses human rights abuse as a course of action. Rather they choose to respond to escalating struggle for social control within 
society by relying, in some cases, on strategies that are human rights abusive. To understand why state elites, in particular, resort to these policies we will first examine some of the theoretical maxims used in the literature on state terrorism. State terrorism concerns itself principally with the gross abuse of human rights which in their extreme form are threats to the very lives of citizens. Theories of state terrorism therefore attempt to explain why states terrorize their citizens and resort to repressive means of governance. Examination of the motivations of state terrorism is worthwhile because it is an example-albeit one of the most severe forms--of human rights abuse and may help us understand the motivations behind other forms of human rights abusive policies. Since our concern with human rights abuse also looks at the initial stages of abuse, which can involve discriminatory legislation that threatens the economic livelihood of citizens--but may not yet be directly life threatening--we are going to maintain that state terrorism is the form of human rights abuse that occurs at the final stages of escalation--that is stages three and four. In the first two stages of excalation the state and other social actors may make conscious decisions which breach their human rights responsibilities but they have not yet resorted to the gross abuse of human rights. The thread that links the various stages of escalation is discrimination so that at each succeeding stage, the state persists in its pursuit of policies that discriminate against one or several social organizations.

This line of enquiry obviously entails several research difficulties some of which we have already noted. There will continue to be difficulty applying responsibility to the state recognizing that it is often not a homogeneous organization but made up of several and not easily identifiable coalitions. We also have to contend with the fact that states 
often deny responsibility for repressive action or human rights abuse and occasionally may even falsify data that would lead to accusations. Thus as Michael Nicholson (1984) notes in studying state terrorism, we face not only an absence of data but intentionally inaccurate data. We must also come to grips with the Weberian notion of the state which allows the state, when faced with increasing social conflict, to attempt to control the conflict through legitimate means. While there is little we can do with the first problem except to critically assess the data before using it, the second problem will be overcome by relying on the issue of discrimination. If the objective of a policy appears to reinforce earlier discriminatory actions it will be considered an illegitimate use of state coercion, ipso facto it is a violation of human rights.

\section{Part 1: Theories of State Terrurism}

Theoretical literature on state terrorism deals with the issue of why states resort to illegal methods of coercion. As such they examine why states go beyond the Weberian standard of legitimate coercion and resort to repression. We will examine some of the main theoretical models that exist before further elaboration of our own framework.

George Lopez in his article, A Scheme for the Analysis of Government as Terrorist (1984) provides a taxonomy of social conflict. He identifies political climate, the circumstances surrounding the initiation of terror, the variety of ideologies that serve to legitimize government terror, the array of terror tactics employed by rulers, the mechanisms that support acts and threats of violence and the outcomes of state terror as possible categories. Lopez explicitly chooses not to posit a causal framework. 
Nevertheless the classification framework does help organize issues that must be addressed in any causal framework. Other authors in the field like Barbara Harff (1987) focus on one particular and the most extreme form of state terrorism - genocide. Harff offers a general explanation of why regimes engage in genocide against whole groups of ethnic or political opponents. She contends genocides $\alpha c u r$ in societies with deep internal cleavages that are experiencing national upheaval and structural change. The upheaval in polarized societies allows the ascent of elites with radical ideologies who choose to destroy rather than merely repress opponents as a demonstration of their power.

Both Harff and Lopez provide interesting arguments. Lopez's taxonomy of terrorism gives some guidance on a number of general variables of state terrorism and human rights abuse but because it is limited to a taxonomy he gives no indication of how the variables link together. Harff, on other hand, begins to dexcribe some elements of a framework but her field of analysis is too narrowly focussed on one very specific form of human rights abuse. In the end, they both offer guidance but not enough information on which to base an analytical framework that focuses on a broader spectrum of human rights abuse.

In 'Governance by Terror,' Raymond Duvall and Michael Stohl (1988) present a causal framework for a wider concept of state terrorism and therefore human rights abuse. They concentrate on the circumstances in which states resort to terrorism and the circumstances in which elites initiate the use of violence by proposing a cost-benefit analysis that takes into account the expected relative costs and effectiveness of state terrorism. 
The relevant and prubably intended features of terror beyond a state of generalized and intense fear, are recognized to include a learned helplessness that atomizes society, leaving each individual standing alone against the violence. When witnesses are unable to predict how, when and against whom violence might be used, they develop a sense of impending chaos. Social life loses the predictability and security of routine existence. Organized resistance seems not only futile but foolhardy as well. Suspiciousness of fellows prevails. Such is the terror syndrome. And such is certainly the syndrome of state terrorism. (Duvall \& Stohl, 1988, p. 239)

Al the heart of the state's decision to pursue terrorism, according to Duvall and Stohl, is a cost benefit analysis based on three variables. The first variable in the decision making process is the perceived benefit of pursuing state terrorism. Stohl and Duvall define benefits as "a state of affairs that is preferable to the actor." The second variable is probability, which relates to the actor's belief that the desired state of affairs would be brought about through terrorism. The third variable relates to the actor's assessment of the probable costs or negative consequences in pursuing state terrorism. Duvall and Stohl's principle of terrorism therefore is based on the actor's belief that in an actual or perceived challenge, state terrorism is a relatively more effective means of governance.

From the cost benefit analysis Duvall and Stohl then propose two syndromes in which state elites are likely to chose terrorism. The first syndrome is the so-called "powerless" states in which there are two subcategories--the new fragile state in which a government perceives itself challenged or threatened by a large portion of society while the second category is the new fragile state which is involved in an actual or perceived conflict with a strongly committed elusive adversary. In both syndromes Stohl and Lopez argue that whatever state terrorism occurs it will be both intense and pervasive. The second syndrome is "out of strength" and is based on the learning proce s of political 
elites. The argument for the second syndrome holds that the propensity to use terrorism is greater if terrorism has been used successfully in the past by the state: if the state believes it can successfully "adıninister terrorism" and if th: target population is vulnerable to ctate terrorism. In this case, the state will reson to terrorism because it can protect some area of its own vulnerability. The out-of-strength syndrome, according to the model is likely to be used by reclusive states.

Finally, looking at suste elites themselves, Duvall and Stohl identify certain variables that affect the decision-making process of individual leaders. The variables include the extent to which human life is valued the general socio-cultural altitudes towards violence and the extent to which the victim or victimized group has been dehumanized by state leaders. The degree of control over the coercive agencies which implement the violence, such as the police and the army, and the extent to which government policy is driven, or believed to be driven, by an overriding obligation to some transcendent mission are also considered important factors in the decision-making process.

Duvall and Stohl conclude there are two "syndromes" of political conditions in which all the variables coalesce and where elites are likely to regard terrorism as costeffective. The first is in militaristic states where the means are available and the second is in an "ideological mission state" where a dogmatic zealous view of target groups is present.

The Duvall and Stohl model has several advantages. It identifies both a typology of state regimes likely to resort to state violence and provides many clues to the decisionmaking process. Most importantly it implicitly argues that state terrorism is not 
accidental; it is the result of conscious, premeditated planning. However, the assertion of conscious rational decision-making in the model faces dispute from a growing body of literature that argues state leaders can often act irrationally. Authors like Ned Lebow (1976) for instance in discussing international conflict point out the role of misperception and human error as impingements on rational decision-making. Other authors, such as John Steinbruner (1974), isolate decision-making contexts and process as contributing to group decisions that are not totally rational. ${ }^{13}$ There is therefore enough evidence to justify caution when using a model based on rational cost-benefit analysis. Secondly the Duvall/Stohl model still presents states and state elites in a dichotomous relationship with society. The model places too much emphasis on state specific variables and not enough on social context variables. There is, for example, no distinction between different types of social challenge nor analysis on what impact the ide itification of challengers has on the decision-making process. According to the conceptual model we have constructed which places importance on the relationship between state and society, ignoring the social context would appear to be a mistake.

Another model to examine is in Ted Robert Gurr's 1986 article, 'The Political Origins of State Violence and Terror.' Gurr's purpose was to specify circumstances in which states and political elites use terror. His definition of state terrorism is coercion "that takes or grossly endangers the lives of its targets." He adds, coercion of this nature

\footnotetext{
'In andition (o) Lethow and Stcinbruner's work there are many other excellent books on the role of perception and misperception in interiuational affairs. For a sample see: Jervis. R.. (1976). Perception and Misperception in Inlcmailkmal Pulitics. Princ'ston. Princeton University Press.. Allison. G., (1971) The Essence of Decision, Explaining Ilu Cuhan Missilc Crisis. Boston. Littk Brown and Co. and Stein. J-G.. \& Tanter. R.. (1980). Rational Decision makiels, lsricl's Scciurity Choicus, 1967. Columbus. Ohio State University Press.
} 
is only state terrorism if it is instrumental, that is, there is a discernable pattern of life threatening actions. Gurr overcomes the first hurdle of assigning responsibility to the state by stating, "...if terrorist acts are pattemed and persistent, if they are directed it opponents of a regime and if authorities make no substantial efforts to stop them, the acts are prima facie state terrorism." (Gurr. 1986a, p. 48)

The distinction between situationally specific and institutionalized state terrorism is Gurr's basis for judging the existence of a pattern. State terrorism which is a response to an open challenge but ceases after the conflict ends is situational whereas, policies that rely on ongoing terror as an instrument of rule are considered institutionalized. Gurr concedes though, that the distinction between the two is not absolute. According to Gurr. policies of state terror may be initiated in response to a violent challenge but in the course of a protracted conflict, develop their own self sustaining momentum.

Based on the these assumptions and limitations Gurr develops four sets of hypotheses related to the nature of the challengers, the characiteristics of the state, the nature of society and the international context. We will examine them briefly. Challengers, according to Gurr are defined as a group, class or party that is perceived by state elites as a threat to their rule.

His hypotheses are:

A1. The greater the political threat posed by challengers the greater the likelihood that a regime will respond with violence.

A2. The greater the latent support for revolutionary challengers the greater the likelihood that a regime will respond with ierrorism. 
A.3. Challengers that rely on terrorist and guerilla tactics are likely to be countered by state terrorism.

A4. Regimes are mcre likely to use terrorism against politically marginal groups than opposition groups ihat have influence on or supporters among the elite.

The characteristics of the state and political traditions are, according to Gurr, more important in the decision-making process then the nature of the challengers. His hypotheses on the nature of the state are:

B1. Weak regimes are more likely to use violence in response to challenges than strong regimes.

B2. Elites who have secured and maintained their positions by violent means are likely to choose violent responses to future challenges.

B3. Successful situational uses of state terror in polarized societies are likely to lead to institutionalized terror and to the preemptive use of terror to maintain political control.

B4. The initial decision of a challenged elite to use terror is usually modeled on others successful uses of state terror.

B5. Democratic principles and institutions inhibit political elites from using state violence in general and terror specifically.

Finally. social structure within a community, according to Gurr, conditions the use of violence. Says Gurr, in ethnically and religiously diverse societies social cohesion tends 
to be low hence challenges to regimes are more common and elites are more likely 10 respond violently.

His social structural hypotheses are:

C1. The greater the heterogeneity and stratification in society the greater the likelihoud that a regime will use violence as principle means of social control.

C2. Minority elites in highly stratified societies are likely to use terror routinely as an instrument of rule.

In the last set of hypotheses Gurr also asserts a country's position in the world order can either constrain or reinforce the use of terror.

Gurr concludes the situational variables $A 1,2,3,4$ directly affect the decisionmaking analysis by including the political traits of the challengers while $\mathrm{BI}$ and $\mathrm{B} .3$ relate to the regime's own political resources for countering challengers. The structural variables $\mathrm{Cl}$ and $\mathrm{C} 2$ are the most important causal conditions by defining the elites relations with opponents and determine how elites constrain their responses. Finally Gurr's dispositional variables B2, B4 and B5 affect how elites regard the acceptability of state terrorism or violence.

In another article (1986b) Gurr also develops a model that could explain escalation in the intensity of coercion among both state and social terrorist groups. By putting different strategies along a continuum of both state and nonstate use of terrorism (jurr postulates that "any shift in the modal intensity of coercion along one of these cuntinua is likely to be matched by a corresponding shift along the other. Once a new equilibrium exists it will tend to persist until one partisan introduces a new tactic." (Gurr, 1986, p. 
16.3)

Criticisms of Gurr's model have centered mainly on one of his founding assumptions regarding the relationship between frustration and aggression. Calling the relationship relative deprivation, Gurr claims aggression occurs when people are irustrated that they are not receiving what they consider to be rightfully theirs. However several authors in the psychology field note the relationship between frustration and aggression is not conclusive. While this criticism is valid in Gurr's theories to explain political violence they are not as valid in theories of state terrorism because Gurr is dealing with responses to political violence rather than the germination of violence. For our purposes Gurr's hypotheses provide a good foundation to understand human rights abuse because of the broad scope of variables. Unlike Stohl and Lopez, Gurr introduces social structural variables that combined with dispositional variables help explain state action. His social structural variables and the consequence of social cleavages also strongly corroborate the construction of our own conceptual framework. However, like Stohl and Lopez, there are several gaps in the model. While Stohl and Lopez use a cost benefit-analysis to explain individual decision making processes, Gurr concentrates on very generalized variables without addressing specific factors that encourage state elites to resort to terrorism. For example. Gurr argues that political elites will resort to violence according to the degree of threat but it is not readily apparent what constitutes a political threat. Gurr's model also suffers from the same weakness as Stohl and Lopez in that he implicitly assumes that state actors act rationally in their decisions to resort to human rights abuse. Overall Gurr makes several assertions that in and of themselves make logical sense. But taken as a 
whole the linkages and relationship between different groups of variables in Gurr's model are not clear. To explain terrorism Gurr's model resembles a model kit that has separate components that obviously fit together but the glue that binds them is absent.

Furthermore as stated early in this chapter, models of state terrorism claim to explain state repression but offer little explanation of how a state arrives at a point where repression is needed. They thus overlook other forms of human rights abuse that may have preceded state terrorism, particularly abuse that is social. cultural or economic in character. For this reason we must return to Migdal's conception of social control to explain social and statelsociety relations and the abuse of escalation.

\section{Part Il: Applying the Notion of Sucial Control}

We left Chapter One having established that a struggle for social control exists between the state and other social organizations. The question to approach now is how do organizations establish social control and can explanation of the struggle to establish social control complement the models of state terrorism and provide greater analytical power to understand human rights abuse?

According to Migdal, the currency of social control is the ability of the state or other organizations to offer "viable strategies of survival." Survival strategies are defined by Migdal as "blueprints for action" that address the population's material needs, such as housing, food and clothing as well as offering a complete set of symbols and beliefs that bind the individual to a group. Survival strategies then, arise from a weave of symbols, tangible benefits and beliefs that support and encourage the formation of group identity. 
Social control rests on an social organization's ability to deliver key components of individual strategies of survival. Most such strategies coincide with existing and accepted belief structure, social myths and modes of behaviour.

These strategies of survival, sewn from the symbols, rewards and sanctions, are the roadmaps used to guide one through the maze of daily life, ensuring one's existence and, in rare instances, pointing the way toward upward mobility (Migdal, 1988, p. 27)

Within this system, state leaders can only seek sustained social control and public support when they have offered viable strategies of survival. (Migdal, 1988, p. 208) As long as other organizations, which may be based on a geographic, economic status or ethnic criterion, offer viable and more preferable strategies of survival, the state can only depend on limited public support. In the context of our model an example of state failure to offer viable strategies of survival could be the vain effort of newly independent states to replace traditional ethnic consciousness and survival strategies with a western notion of national strategies based on an allegiance to the nation-state. The struggle for social control thus is based on the competition among state and social organizations to offer widely accepted political survival strategies. The prerequisite for states to offer viable strategies "re strong state agencies that provide a mixture of sanctions and rewards to the general population and thus can gain popular mobilization. This gives rise to what Migdal identifies as a paradox for state leaders. State leaders need strong agencies to secure social control but strong agencies can also become a source of opposition and therefore a competitor for social control. To counteract either increasing social control within separate parts of the state structure or outside of the state structure, state elites may resort to self- 
protection strategies. One of these strategies identified by Migdal is "dirty tricks."

These actions, at times initiated by top-ranking state personnel, have included illegal imprisonment and deportation, strange disappearances, torture and death squads. Here the difference from other sorts of politics of survival has been that state leaders have transgressed the very laws that could serve as a basis for instituting social control.(Migdal, 1988. p. 223)

In some ways dirty tricks are the most obvious manifestation of the paradox facing leaders in that they chose to respond to competition by undermining the very tools needed to secure social control. Dirty tricks are in essence, says Migdal, attacks on the state's explicit or implicit rules of the game, its legal code and established modus operandi hy the leaders of the state themselves. The potential use of dirty tricks against rival soxial organizations is thus one factor to be considered in the attempt to understand human rights abuse at the national level.

Remaining at the national-level of analysis, there is an additional element of social control which may aid in our understanding of human rights abuse. According to the model developed so far, when social organizations gain a significant measure of social control it often appears to be at the expense of the state. In an environment where saxial control rests with nonstate organizations then the state likely has litte ability to control the activities of these empowered social groups. It is possible therefore that once free of state restraint, in terms of enforcement and rule of law, sccial organizations resort to various human rights abuse to advance their own goal's and vision. ${ }^{14}$ Of course if the

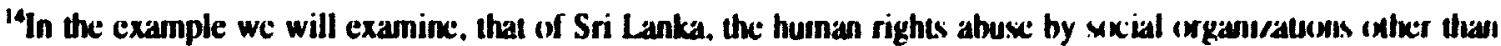
the state was mainly abuse of civil and political rights. Within the framework toungh. It can be asxerted thad wxial organizations may rexon to other forms of abuse and follow a similar pattem of abuse cxalation as the stalc. Iror example, the American Ku Klux Klan not only resonted w abuse of civil and political by terrorisng wnuthem blacks. but they also actively sought to damage black economic interests. The Ku Klux Klan was also by its very nature discriminatory in terms of who they alkowed to become members of the organisation.
} 
state has resorted to dirty tricks itself and undermined trust in the rule of law, social organizations may have even more freedom to also ignore the rules of law. In summary, social groups which have achieved a large degree of mobilizational and militant capacity may operate outside the rules of law and state agencies may be powerless to prevent social organizations pursuing their own ruthless and rights abusive paths.

Finally, it appears clear from the work of agencies like Amnesty International that human rights abuse may not necessarily be initiated by state leaders or "strongmen" alone at the peak of social organizations. State leaders depend on middle level managers to implement social policy. Quite simply it is the administrators that establish the rules of the game at the ground level. Administrators too face pressure and conflicting strategies of social control. (Migdal, 1988, p. 248) In the case of a state losing social control at the top, the result at the lower levels of bureaucracy may be less support and enforcement on Ioval officials which make them more susceptible to social control by community level strong men. Buffeted by pressure from other social groups, local administrators and strongmen thus reflect the battle for political survival and social control that is taking place at higher political levels. And--here is the crux--there may be occasions where local administrators or community level strongmen resort to human rights abuse in the community level struggle for social control. This then is the third potential level of human rights abuse which must be monitored.

Using some of the maxims from state terrorism and Migdal's concept of social control we can now conclude the construction of our own framework to monitor exalation of human rights abuse. We will start with the formulation of some general 
relationships which may impact on human rights abuse and then couple them to the escalation model to demonstrate how human rights abuse may hegin with discriminatory legislation and excalate to gross human rights abuse or state terrorism. It should be noted that I have tried to avoid the subject of causality, instead portraying the relationships as areas we should be aware of in order to understand human rights abuse in ethnically divided societies.

\section{Part III: Arriving at Some (ieneral Relationships}

\section{AI Does the alignment of social and economic cleavages in vertical formution enuble a regime to use discrimination in order to increase sucial cuntrul and advance its own political goals? (Precondition)}

In this case we are taking the general structural variables of a vertically differentiated society marked by intense intergroup rivalry from the conceptual framework and using it as a possible precondition for some forms of human rights abuse. According to our framework in a society where social groups are organized somewhere betn'e'n the extremes of vertical or horizontal organization then they are more likely to have a heterogeneous character and intergroup conflict is likely to be less. In a completely vertically differentiated society, based on ethnic affiliation, there may be very little crossgroup cooperation or very few--in extreme cases none at all--social groups which have hetergenous membership attributes. The same picture may also occur in a completely horiziontally differentiated society which increases the likelihood of conflict. Therefore an environment between the two extremes may be comprised of hetergenous social groups 
which restrain state elites from pursuing systematic discriminatory policies since there are no significant homogenous social organizations that threaten the state's attempts at social control. In the absence of strong social groups there would also be nn exsiiy identifiable groups to discriminate against. The absence of a we/them social mentality could also inhibit the formation of powerful state-threatening social groups. On the other hand in a scciety where social groups are aligned in vertical fashion--such as the potentially rights abusive society we have identified-it becomes easier for state elites from one group to identify another group. In addition. a social formation of vertical alignment may indicate both intense intergroup rivalry and the presence of strong social groups which are able to threaten the state and increase the likelihood that the state would attempt to exercise social control over one group by discriminating against the other.

A2. In a highly stratified suciety are moderate elites from all social groups present in the state ciecision-making apparatus? (Inhibitor of escalation)

The second relationship to monitor relates to factors that may inhibit the use of discriminatory policies. It posits that if moderates representing all social groups are present in the decision-making apparatus then the state may be less likely to pursue a discriminatory policy and therefore less likely to resort to further human rights abuse beyond dixcrimination. The presence of elite moderates in state decision-making bodies may also signify that many social organizations have access to state structures thus reducing the likelihood that one or two social organizations gain control of state agencies. In this case political elites may be less likely to face "the paradox" and therefore less 
likely to resort to dirty tricks. The relationship is also based on several of Gurr's hypotheses that state elites are less likely to resort to state terrorism if democratic principles are adhered to and opposition groups have some influence on state elites.

\section{A3. With the dispersion of sucial cuntrol away from the state, is there a struggle between the state and strungmen to exercise greater social cuntrul? If there is a struggle, does it contribute to human rights abuse at any one of three levels already mentioned? Furthermore has human rights abuse become worse as the struggle for social control escalates and the state loses whatever degree of social control it had previously owned? (Incentive for further escalation)}

The third and final relationship to monitor is based on what I have described as the three levels of human rights abuse. It is also supported by both the Gurr and Stohl/Duvall hypotheses of learning in a social conflict and state terrorism. Both models suggest that state elites who have successfully used state terrorism in the past will again resort to the policy: The logical extension of this is that state elites who have resorted to discrimination in the past to strengthen social control may again resort to discrimination in escalating degrees to protect their public support. The tendency to sesort to further discrimination is also based on the degree of social challenge. The expectation is that a regime faced with violent challenge to their social control must decide between either rescinding the policies that led to the challenge or reacting with greater abuse of human rights. Choice of the latter option may lead to excalation and ultimately the institutionalization of human rights abuse which is persistent and pervasive. 
We must now turn to combining the relationships and linkages to with the idea of conflict and human rights excalation. In the first stage - the political mode, the model suggests, state and society are closest to an ideal equilibrium. At the first stage the preconditions of human rights abuse may exist in terms of the characteristics of society but all, or the majority of social organizations, are involved and represented in the political piocess and have faith in the ability of the institutional processes to resolve differences, albeit imperfectly. In order to reach the second stage we have to monitor whether elites in the larger majority determine that pursuit of discriminatory policies against the less powerful groups will bring the reward of a greater share of social control. We are also suggesting that the decision by majority elites might be accompanied by the ostracism of minority elites from the political process, allowing the majority to implement its agendi. At the second stage, the presence of discriminatory policies would mark an escalation of human rights abuse entailing the violation of the human rights of minority segments of society. As the majority elites implement the agenda, one must also be aware of minority groups" possible attempts to gamer social control by gathering the allegiance of victimized groups. The second level of escalation may also witnesses diminished access for minority groups to both political machinery and economic resources. If protest turns to violence or if the state reaction to protest turns violent, escalation moves to the third stage. The third stage would mark the state's attempts to regain control with greater coercion. In this stage we must be aware whether the widening of cleavages in society and the encouragement of an us/them polarity fosters the dehumanization of opposing soxial groups which in turn facilitates greater human rights abuse. Faced with violent 
challenge and dehumanization of opponents and successful use of discrimination at carlier stages the state may also sponsor or turn a blind eye to further abuse of human rights. The final stage marks the institutionalization of abuse and the violent attempts of other social groups to apply their concepts of social control. At this stage conflict may develop into a full blown civil war where both sides subsume all human rights to the necols of battle. 


\section{SFC:TI()N TW( ): A SRI LANKAN ILIUSTRATION}

\section{C.HAYIKK FOUR: SRI LANKA, $1948 \cdot 1983$}

\section{Part I: Introduction}

Sri Lanka, at the time of its independence in 1948 was known as a tropical paradise and a potential paragon of development. By 1983, the hopeful aspirations had long since disintegrater as the island suffered growing ethnic hostility and civil war. ('ontrary to social myths propagated by both sides, the ethnic division of the island was a 20th century phenomenon and bears witness to the social forces we have been discussing. It is the record of deepening ethnic cleavage encouraged by Sri Lankan politicians who attempted to harness and employ ethnic nationalism but quickly became overwhelmed by the forces they had unleashed. It is the story of an ethnic minority when subjected to state dixcrimination increasingly looked to itself to draw up rules and standards of behaviour that we earlier defined as social control. And finally is the account of a roused ethnic majority struggling to regain control of "their island" and "their destiny." The struggle once begun ostracized the moderates. Idealistic and disenfranchised youths on the one hand and extreme ethnic nationalists on the other often set the agenda and the instruments of the confrontation represented in many cases a form of human rights abuse.

As we anticipated, instances of gross human rights abuse did not abruptly appear but were the culmination of a series of excalatory steps that began with ciiscriminatory legistation designed to appease those in the Sinhalese majority who saw themselves as the long suffering victims of colonial perfidy. As much as the roused nationalism was 
difficult to turn off so too was the majority's expectations that "affirmative action" was needed to remedy colonial injustice. The incorporation of language legislation into a new constitution in 1972 and educational reform were instances of ethnic affirmative action but their impact on the minority Tamils only further stimulated ethnic solidarity and a shift of social control awdy from the government. In the last decadte, theset by insurgency. the government resorted to far reaching emergency legislation that deprived the minority Tamils of judicial protection and encouraged an undisciplined security force to abuse international norms of human rights. The loss of social control by the government also appeared to have encouraged chauvinistic elements within the government to uxe private 'goons' to block and harass mediation efforts of the government and encourage widespread acts of violence and torure against the Tamil minority.

Paradoxically the former British colony of Ceylon has been both condemned for its virulent ethnic hatred and praised for ts far resahing social and political experimentation. It was the first Asian country to have implemented universal suftrage--a full 20 years before any other African or Asian colony. At independence it enjoyed a social welfare system that included free health care and free education with resulting high levels of literacy and quality of life indicaiors which rivalled many of the developed countries. (Manor, 1984, p. 2) In 1978, the original Westminster parliamentary system was changed to a Presidential system. Since then power has generally alternated between the centre-left Sri Lanka Freedom Party (SLFP) and the centre-right United National Party (UNP) although the UNP has been in power since 1977. 


\section{Part II: Listurical Backeround and Farly Cummunal Relations}

The demographic history of the island begins around $5(x) \mathrm{BC}$ with the settling of the Sinhalese. Originating from Northern India, the Sinhalese now make up about 74 per cent of the 16.6 million population (according to the 1988 census) ${ }^{15}$. Geographically dominating most of the island, the Sinhalese are concentrated along the western coastal bell and in the western province around Colombo. According to the Sri Lankan historian K.M. de Silva, what observers find most remarkable about the Sinhalese is their conception of themselves as the chosen guardians of Buddhism and Sri Lanka as its place of sanctity.

This intimate connection between the land and the race and the Buddhist faith foreshadowed the intermingling of religion and national identity which has always had the most profound influence on the Sinhalese. (K.M. de Silva, 1976, p. 74)

The other main demographic component of Sri Lanka is the Tamil minority. The Sri Lankan Tamils, which are different from the Estate Tamils--to be described later-settled on the island a few centuries after the original Sinhalese settlement. Originating from Southern India, the Sri Lankan Tamils comprise about 13 per cent of the population and are concentrated in the Northern Province of Jaffna where they form an overwhelming majority. The Sri Lankan Tamils are also located in the eastern province where they are predominant in some areas but in total make up roughly a third of the population along with equal numbers of Sinhalese and Muslims. Up to the troubles of 198.3 many Tamils were also located in the capital region of Colombo.

\footnotetext{
"Scurce: Cialiddiaul Intcrnationtal Development Agency. Canadlian Development Cooperation in Asia: Sri Lanka. Asta Brallih. Jubie 149(1)
} 
Since the establishment of a Tamil Kingdom in the northern regioms in 1.3th Century the Tamil and Sinhalese areas have been separated by a broad forest belt in the central part of the island. The early migration of some Sinhalese-- now called Kandyan Sinhalese ${ }^{16}$--to the central highlands and recent settlements around several irrigation projects has reduced the geographic barrier between the two peoples. Despite the separation which continued until the 19th Century the two cultures were socially and economically linked with few of the tensions that were to arise later. As further indication of nonconfrontation many authors point to evidence of intermarriage between the (wo 'races.' (Wriggins, 196(): Manor, 1984: Ponnambalam, 1983)

Having described the relative harmony between the two communities, the myth that ethnicity and religion have separated the Tamils and Sinhalese since the early days of settlement is equally important in understanding the Sri Lanka crisis. The image of the Tamils as the implacable enemy, says K.M. De Silva, has been etched deeply into the minds of the Sinhalese and magnified far beyond historical fact through local folklore and mythology. Much of the myth and folklore has been spread by the Buddhist Bhikkus. As a combination of religious teacher and holy man, the Bhikkus have become highly articulate political spokesmen often using parables, fiction and poetry to communicate with the masses. In the mid-1950's, in the absence of Sinhalese newspapers, it was the

\footnotetext{
${ }^{16}$ The agricultural-orientated Kandyan Sinhalese have been differentiatted from the Low Country Sinhtalexe wins remained on the coast pursing a more entrepreneurial urban lifestyle. Aside from geasgraphical dillerences the Kandyan Sinhalese and Low-Country Sinhalese also differ in caste. Approximately $85 \%$ of the Karndyans are Itron the Goyigama caste which is considered the elite caske in the Sinhatese Buddhist system. In comparixm cmly 51 'K of the Low-country Sinhales a are part of the Goyiganna caste while 17\% are from the Karava caste. Since Brotish colonialism there has been rivalry between these two castes for political powcr with most of the front-line Sinhedese zealots coming from the Karava caste. Source: Ponnaunbalam. S.. (1983) Sri Lanka, the National Questiun and the Tamil Liberation Struggle:Londen. Zed Books Inc. pg 27
} 
Bhikkus who conveyed political events and Buddhist principles to Sinhalese villages. (Ponnambalam, 1983) The mythic exaggeration of two implacable enemies has also been significantly influenced by the Sinhalese's geopolitical perception of themselves as a minority surrounded by millions of Indians immediately to the north. They fear most an assault against the Sinhalese culture and language by a united Tamil culture. This fear had until recently proven to be unfounded since the Sri Lankan Tamils were equally quick to point out their cultural distinctiveness from Indian Tamils. It was only under what the Sri Lankan Tamils perceived as sustained discrimination and menace that the connections between Jaffna and Tamil Nadu have been strengthened.

In the late 19th and 2(kh Centuries another element of Sri Lankan pluralism was introduced by the British colonial administration--that of the Estate Tamils. Originating from lower castes in Southern India, the immigrant labour was settled in the central highlands to work on the tea plantations. Their presence in large numbers--they totalled approxinutely 1.6 million in 1981 --contributed to the grievance felt by the Kandyans who resented both the influx of population and the conversion of land to plantations by colonial powers and low country Sinhalese. Since 1948 the future of the Estate Tamils has been very insecure. Deprived of citizenship rights in 1948, large numbers of them uere regarded as stateless people with citizenship neither in India nor Sri Lanka. In 1964 both governments reached an agreement that was to see some Tamils repatriated to India in return for Sri Lankan citizenship for all remaining Tamils who had not previously been alcorded citizenship. The continuation of ethnic hostilities though stalled and thwarted this process. One result of the citizenship problem was the historical exclusion of Estate 
Tamils from the benefits of Sri Lanka 's welfare system. Estate Tamils had until recently suffered extremely difficult working conditions. poor education and health services and little security.

Another component of Sri Lanka's cultural and religious character are the Christians. The advent of Portuguese and Dutch colonialism introduced Christianity. At their current level Christians, both Sinhalese and Tamils, make up 7.5 per cent of the population. Over the long term Christianity has typically become assoxiated with certain benefits, like improved education, especially for those elites working within the colonial system. To this day, Christians, because of their association with the colonial administration, are still perceived as a privileged group. The last Iwo groups in the Sri Lankan mosaic are the Muslims Moors and Burghers. The Moors originated from cistiy trading settlements and now make up approximately 7.1 per cent of the population. They have historically tended to act as an autonomous group finding accommodation with which ever party was in power. The Burghers are descendants of Portuguese and Dutch expatriates. Since the outbreak of ethnic hostilities though many have left the island and they now make up less than one per cent of the population.

Before examining the escalation of conflict up to 1983 it is also neccessary to provide some historical context to some themes that were, and still remain, significant to the ethnic tension in Sri Lanka. The first is the role of religion in state affairs. In the 1840's under evangelical pressure the British severed the link between Buddhism and government. The move removed the bond between Buddhism and the Sri Lankan rulers 
which had existed since the early days of the Sinhala kingdoms. The act is historically significant since it became the source of revived Buddhist pressure to provide Buddhism and the Sinhalexe language with protected status.

The other theme of importance is the historical role of employment in the colonial bureaucracy. In Sri Lanka, as in many colonies, work in the public service was viewed as an extremely r. estigious and secure position. As Vijaya Samaraweera, local recruitment to the civil service tend to be viewed "not as a success of a gifted individual but as a comparalive social group success and this was perhaps the best indication of the competitive spirit which developed among social groups in the areas of education and employment." (cited in K.M. De Silva, 1976, p. 79)

Originally the Burghers were prominent in the civil service but around the turn of the century faced stiff competition from Sri Lankan Tamils. The limited economic resources in the Jaffna region and an expanding population meant many Tamils were unable to find work in the traditional farming sector. Helped by an efficient network of Christian mission schools in Jaffna, the Tamils turned to state employment and professions such as medicine, engineering and law. Importantly, as a result of successful plantation and trading activities, low-country Sinhalese did not seriously compete for public xervice positions until the early 20th Century. When the Sinhalese did turn to the state for employment they found the Tamils well established. Says K.M. De Silva:

Indeed the Tamils had come to be singularly dependent on government service and thus tradition was so strongly established among them that when potential Tamil recruits exceeded the number of opportunities available in the island, the more enterprising among them emigrated to the Federal Malay states in large numbers in search of similar employment there. (K.M. De Silva, 1976, p. 79-80) 


\section{Part III: Prelndependence and Independence - Stake ()me}

Preparation for independence from Britain began in the 1420\% with the Donoughmore Commission and subsequent Donoughmore Constitution in 19,31 which provided for universal suffrage and self-government. The provision of universal suffragke was based on the British assumption that expansion of the franchise would broaten the base of political activity and lead to a greater measure of political integration betweren the Sinhalese and the minorities when the time came for a transfer of power. (K.M. De Silva. 1976: Arasaratnam, 1979) For their part, the minorities led by the Tamils made it clear that they were opposed to any constitutional provisions that did not provide for a system of checks and balances to protect their interests. Tamil leaders during this period werc very much part of the political negotiations with Britain and vocally expressed concern that they would be swamped by the Sinhalese majority under a one-man-one vote system. Instead of supporting universal franchise they proposed a system based on communal representation for the new state legislature. Flatly rejecting communally-based representation, the Donoughmore Commission eventually favoured a system of territorial representation.

Despite the obvious apprehension of the minorities and caution of the comminsion it seems clear in retrospect that neither the Tamil leaders, lulled into a false wense of security by colonialism, nor the commissioners, quite envisioned the rixe of Sinhalcse nationalism that was to follow. The risk taken by the Donoughmore Commission to open up suffrage to all and "elevate political conflict to ideological and national levels was an 
utter failure."(Arasaratnam, 1979, p. 505) Far from enhancing political integration, the Donoughmore Constitution strengthened communalism on the island. The result was the first indication of long lasting ethnic cleavage in the boycott by the Tamils of the first election under the Donoughmore Constitution in 1931.

By the early 1941 's the British wanted to guide the Sinhalese politicians towards some sort of settlement with the minorities before independence. The result of their efforts was the Soulbury Constitution of 1945 which contained protection for the minorities. The prolection was clause $29(b)$ which prohibited Parliament from enacting any laws which discriminated against ethnic or religious groups or gave advantage to any particular ethnic community or religion. (Jeyaratnam Wilson, 1988, p. 20) Although the clause did not provide the degree of protection desired by the minorities it was considered a constitutional guarantee of sorts. The British reluctance for more entrenched constitutional protection of the minorities has been attributed in part to the British constitutional tradition of an uncodified bill of rights; but it was also attributed again to the failure of the British and the Tamils to truly appreciate the potential domination of Sinhalese nationalism.

Far from presenting themselves as a communal colossus waiting to crush under their feet the numerous other minorities, the Sinhalese appeared to an impartial observer to be an unorganized, disadvantaged people relatively backward in educatior: and with large pockets of rural poverty and indebtedness. (Arasaratnam, 1979. p. $5(15)$

Subsequent history shows the Soulbury provisions were not effective but the extent of dialogue and the mood of the day is important to consider. During the period prior to 
independence the two cultures had existed side by side for centuries. altweil with wome mutual suspicion but none of the hostility that was to mark latter years. As Harold Wriggins noted. there was little evidence of conflict between the Tamils and Sinhalese prior to 1955-56 largely because the two cultures had maintained a self-conscious separation.

Where members of both communities had lived together for generations as neighbouring peasants and villagers, there developed a reasonable degree of understanding and mutual tolerance. They were self-conscious about their differences, and mutually suspicious, but they were not intensely hostile prior to the language agitation of 1955-56. (Wriggins, 196(), p. 231)

This carefully maintained balance between the two various religious and ethnic groups was, according to K.M. De Silva, (1986) conscientiously pursued by Sri l.anka's first Prime Minister after independence. In fact. according to De Silva it was Don Stcphen Senanayake who was largely responsible for maintaining the balance of forces during his tenure. Senanayake, writes De Silva. understood the implications of Sri Linka's plural character more than his contemporaries and modelled his policies on that understanding. When he formed the UNP he attracted most of the leadership of the 'Tamil Congress and thus created an equilibrium of forces. He was also the most influential advocalte of Sri Lankan nationalism which emphasized the interests of all the island's ethnic and religious groups through a process of reconciliation.

It was based on a double compromise: the softening of Sinhalese duminance by the establishment of an equilibrium of political forces whose keynote was moderation, and an emphasis on securalism, a refusal to mix state power with religion even though the concept of a special responsibility for Buddhism was tacitly accepted. (K.M. de Silva: 1986, pg 156) 
It was actually the widely accepted stature of D.S. Senanayake and the confidence he inspired that persuaded the Tamils to accept the constitutional provisions in the Soulbury Constitution despite misgivings. Furthermore, says De Silva, it was also Senanayake who kept the Buddhist Bhikkus at bay in spite of their displeasure over the continued prestige of Christians. The relative absence of ethnic violence during this period is reiterated by K.M. de Silva (1976). During Senanyake's tenure, he writes, there was little evidence of religious turnoil that was to erupt in the mid-1950's.

In the country at large there was an impression that a seemingly intractable problem-that of the indigenous Tamils--was being solved on the basis of reconciliation and compromise. (K.M. Silva: 1976, pg 83.)

The only group not to be included in the balance of forces created by D.S. Senanayake were the Estate Tamils. One of the first acts of the new country was to render many of the Estate Tamils stateless on the grounds that they could not meet the stringent requirements of citizenship prescribed by Senanyake. The strict requirements of citizenship reflected the degree of concern among Kandyans that their representation would be greatly diminished by the sheer numbers of Estate Tamils. The results of this exclusion were predictable. It allowed the rural Sinhalese voters, especially the Kandyans, to dominate in the constituencies where there were large numbers of Estate Tamils. Not only did the exclusion of the Estate Tamils guarantee the political ascendancy of the Sinhalese. compared to the rest of the island, but also gave rise to the deplorable conditions the Estate Tamils were later to suffer. On this episode Jeyaratnam Wilson 
writes:

In the decades since independence, there has been evidence of Sintaslese-orientated 'national' parties (by which we mean parties contesting seats in a majority of constituencies) winning majorities after disenfranchising the Indian population. annexing the 8-14 seats that would have gone to them, and enacting legislation that provided favoured treatment to the ethnic majority. (Jeyaranam Wilson. IVXK. p. 19)

In the larger context and under the microscope of analysis. Sri Lanka in the perioxt just prior to independence and immediately after was a society characterized by almost vertical formation. ${ }^{17}$ The two major social groups tended to be autonomous organizations based on ethnic, religious and geographic separation but with several cross membership ties which mitigated the extent un vertical formation. Economic and social links existed between the two groups, although tenuous and fragile. The character of Christian groups at the time, comprised of both Sinhalese and Tamils, also suggests cross group affiliations. According to R.L Stirrat (1984) the Catholic Church prior to the Donoughmore Commission was a relatively cohesive group. Cleavages within the country were principally religious between Catholics and Buddhists and Hindus. This carly picture of the Christian community is markedly different from that of a century later.

Most conflict now takes place across ethnic and not religious boundaries. From being a unified, self-confident and assertive body, the Catholic Church as an institution today tries to keep out of politics and avoid any actions which might offend the Sinhalese-Buddhist dominated state. Rather than stress a common religious identity. Catholics today are divided on grounds of ethnicity, a split which affects not only the laity but also the priesthood. (Stirrat, 1984, p. 197)

\footnotetext{
${ }^{17}$ See the discussion on verical and horianntal sxilal formation in Chapter Orwe asd Chapter Three.
} 
Evidence of class-based violence where it existed also reveals a degree of cro'ssmumbership ties best emphasized by the railway strike of 1912 and the general strike of 1923. The rash of strikes in the early 1920's were in the words of A. Sivanandan "creating in the process an urbar working class united across caste, creed and community." (Sivanandan, 1984, p. 8)

Harold Wriggins also points to English speaking schools as another crossmembership link among the political elite. "From this experience, the cultural diversities were in many ways bridged. Intimate friendships and a substantially common view of life, putibic purpose, and private enjoyment came to be shared by many English-educated in both Sinhalese and Tamil communities." (Wriggins, 1960, p. 230)

Far from being a truly plural society, Sri Lankd up to the 1950's did appear to exhibit some cross ethnic co-operation. Social control at the time was still firmly planted within the political elite who shoved faith in the political process to resolve their differences. It was not long though before the Tamil leaders began to realize the unitary, consociational state that had been envisioned by the Soulbury Commission was nut to be. Race riots and accompanying human rights abuse had not yet forced their way onto the scene. Nevertheless, the exclusion of citizenship for the Estate Tamils at independence ominously revealed the forces waiting to upset the balance.

\section{Part IV: Linquistic Nationalism, 1956-1965 - Stage Two}

In July 1951. S.W.R.D. Bandaranaike crossed the floor, leaving the United National Party and forming the Sri Lanka Freedom Party. It was largely to the Buddhist 
activists and rural population with a deep sense of injustice with regard to religious. language and cultural issues that the : .PF appealed. In the process the neu party and leader abandoned both the Sri Lankan nationalism advocalted by D.S. Senanayake and the Tamil parties by directly encouraging a new form of nationalism that was brazenly Buddhist and Sinhalese in content. The impact of the neu nationalism was felt during the elections of 1956 when the fragile equilibrium constructed by D.S. Sconanayake was destroyed and replaced over the next decade by ethnic hostility in which the Tamils suffered a series human rights abuses. The language debalte. Which ${ }^{2}$ as at the centre of the 1956 elections, strengthened ethnic cleavages, reduced govermment social control in Sri Lankan society and manifested itself into a series of riots in 1958 which for the first time engulfed the whole island.

The events of 1956 were not all orchestrated by S.W.R.D. Bandaranalke. lixternal or accidental circumstances also contributed to the deteriorating situation. The first external contribution was the world-wide celebrations in 1956 of the Buddha Jayanthi the 25(K)th anniversary of the Buddha's death. Surrounding the celebrations was a relighous fervour that took on almost messianic dimensions and acted as a calalyst for the new kind of romanticized nationalism that was enveloping the island. The second contributing event was the accidental death of D.S. Senanayake in March 1952. His loss meant the removal of a prestigious advocate of Sri Lankan nationalism.

The evolution of the language debate began with the 'Swabasha' movement in the late 194(1)'s. Swabasha stood for the replacement of the English language in the public service and education by both vernacular languages. In 1951, the government established 
the National langlage Commission to monitor the implementation of both national languages. At the time S.W.R.D. Bandaranaike was an enthusiastic supporter of gradual implementation of Swabasha. But in 1951 he used the delay in pursuing Swabasha as the reason for crossing the floor. Having done so, Bandaranaike then committed himself to specdily implementing the program and abandoning the caution he had espoused in the $19411^{\circ}$

('onirrently during the mid-51)'s and preparations for the Buddhist Jayanthi. Buddhist groups and the Sinhalese educated intelligentsia were becoming increasingly agitated that the dominance of English was excluding them from their share of the power and unjustly giving greater advantages to the Tamils who benefited from a superior Inglish education. This group set their sights on the language issue and soon began demanding the replacement of English by "Sinhala only." (K.M. De Silva, 1986, p. 172 \& 173)

Wriggins, in an indepth analysis of the evolution of the language debate states,

It is difficult to specify exactly when the Sinhalese and Tamil languages became pitted against each other in a competitive search for the 'final' solution to the 'language problem.' When this happened the dispute took on a more embittered tone and led to sharpened communal tension. It is evident that the ground shifted gradually. Key decisions of a fairly technical nature became slogans for public debate. Careful analysis of inherently intricate and delicate problems became more difficult as arden: Sinhalese whittled down the position of the Tamil language and the Tamils sought to defend their own position and status as these became involved in the status of their language. (Wriggins, 1960, p. 250)

Against the backdrop of these pressures in February 1956, the UNP held its annual congress. During the deliberations the party unanimously decided to abandon its policy 
of gradual implementation of Swabasha and pursue a Sinhalexe-only policy. Sir John Kotelawala. who had replaced D.S Senanayake's son. Dudley. as the leader of the IINP. immediately after the conference called for the dissolution of Parliament. During the 1456 elections the language debate became the issue and in the deteriorating process the two communities became mutually antagonistic. The cries of one community-ceven if defensive--tended to mobilize the defensive consciousness of the other.(Wriggins, $19(x)$. p. 253) And as communal tension rose, untrealistic political images of each side treamk widespread. Partisans on each side tended to take the extreme statenkents of their opponents as representative of the attitude of all others. Thus bitter atlacks on the Tamils by communal organizations in the south were taken by Tamils as reprexenting the Sinhalese view and extreme spokesmen for Tamil federalism came to reprexent the Tamil view to more and more Sinhalese. (Wriggins, 19(x), p. 25.5)

The result was effective communication between leaders of the communities one of the interethnic bridges--began to diminish. Equally important was the sidelining of the moderates within both communities. Again Wriggins writes:

There were still large number of moderates /both Sinhalese and Tamill who deplored the growing rift between the two communities. There were many others who privately regretted the growing communal antagonism that developed as a byproduct of agitation over the matter of state language. But like moderates

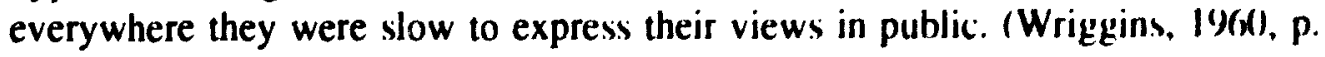
256)

Since, in large part, the moderates represented the most westernized of the Tamils and Sinhalese, the explanation for their self-imposed ostracism was guilt, according to 
Wriggins. Many of them, he states, felt they deserved criticism for allowing themselves Io ignore their own culture and language and therefore found it wiser to remain on the sidelines rather than expose themselves to polemic attacks. (Wriggins, 196(), p. 257)

An important aspect of the hostile inter-communal perception was the use of a vision-for purely electioneering purposes--of the Tamils as the ultimate enemy of the Sinhalese. "Many political opponents of the UNP," says Wriggins, "and some spokesmen for it painted the 'Tamil threat' in such lurid colours for electioneering purposes that communal tensions were higher then they have ever been. except for the communal riots of 1915." (Wriggins, 1960), p. 261)

For the Tamil community the implications of the Sinhala-only language policy were bleak. Says. K.M. de Silva, it amounted to a clear betrayal of the promises given to thein at the transfer of power and a violation of the principles that were supposed to be constitutionally protected. In economic terms, the Tamil's reliance on public service employment, and to some extent the proiessions, were seriously jeopardized. More importantly. once language became the determinant of national identity then the Tamils, says K.M. De Silva, faced cultural assimilation as the price of continued residence on the island. In 1956, in reaction to the $r$ oposed language policy, the Tamil Federal Party at its convention at Trincomalee set out a list of demands which included: Autonomy for the Northern and Eastern Provinces under a federal constitution, parity of status for Sinhalese and Tamil languages and a satisfactory settlement of the Plantation Indian problem. Following the demands, the Sinhalese community became aghast at the implications. (Pomambalam, 1983. p. 106) 
In 1957. Bandaranaike conducted negotiations with the Federal Party eventually agreeing on a number of conciliatory provisions. There $u$ as agreement that Tamil uould become an official language for administrative purposes in the Northern and Eastern provinces, agreement on a xheme to devolve administrative pouers to regional councils and promises of restraint on the number of Sinhalese settlements within irrigation $x \cdot h \cdot n k \cdot s$ in the Northern and Eastern Provinces. However, the moment the terms of what tocaurx krown as the Bandaranaike-Chelvanayakam Pact were made public there was a storm of protest and Bandaranaike abrogated the ayreement. To soothe Tamil feelings he conceded a bill to allow for reasonable use of Tamil in adminstration but although the bill was approved by Parliament, regulations for its effective implementation were never approved. (K.M. De Silva. 1976 \& 1986)

Following the assassination of S.W.R.D. Bandaranaike in $19.5 \%$ by a Buddhist monk, his widow, Sirimavo Bandaranaike, took over leadership of the SI .FP. In July IU(x) the SLFP was returned to power after a brief interlude by the UNP. Her successful election was based in part on the support she received from the Federal Party in exchange for implementation of the Bandaranaike-Chelvanayakam Pact--but Mrs. Bandaranaike too, reneged on her commitment under pressure from Sinhalese and Buddhist extremists.

While the language issue was predominant during the SLPI: tenure other disputes-specifically the Indian Tamil problem and the school takeover--also raised communal hostility. Following the 1948/49 citizenship legislation the bulk of the Indian Tamils were deprived of Sri Lankan citizenship. S.W.R.D. Bandaranaike, prior to his assassination did little to address the issue but in 1964 his widow achieved a breakthrough in negotiations 
with the Indian government. Previously, the Indian government had refused to accept that the Plantation Tamils were entitled to Indian citizenship let alone accept their repatriation. After the death of Nehru, who had stalled negotiations, an agreement was reached that $525,(x)$ of the Indian Tamils would be repatriated while $3\left(Y_{1}\right)(x)(x)$ recieived Sri Lankan citisenship. The fate of the remaining $150,(x)(x)$ was to be decided later.

Shortly after Mrs. Bandaranaike's success, in an obvious effort to appease Kandyan fears, she moved to limit the freedom of the Tamils who had just been promised Sri Lankan citizenship. Her proposal was to have Plantation Tamils placed on a separate electoral list. It was a patently discriminatory move since the Tamil list was obviously to be one of inferior status. The proposal was never implemented after the UNP promised to retract the idea in the 1965 elections.

On the schools issue, discrimination and calculated opposition against the Christian minority was also a component of the SLFP's policy. In 1961, state-aided schools were absorbed by the state in an effort to exert greater Buddhist influence on Christian schools. Most Christian schools had zealously guarded their autonomy and avoided hiring nonchristians. According to C. R. De Silva, evidence suggests the Buddhists were concerned with limiting the spread of Christian influence and removing the special advantages of Christian students. The results however showed that the schools, even after absorption, stayed the same; same staff, students and principals. The most visible change was that schools were not able to levy school fees which meant those schools that stayed private faced real economic difficulties. (C.R. de Silva, 1979, p. 482)

The tension prevalent during discussion and implementation of these initiatives 
soon manifested themselves into violence. In response to the government's plan in 14.57 to introduce Sinhala only. the Federal party in 1956 staged a satyragraha opposite the Houses of Parliament. The protest ended up in violence spreading through (olombor) and eventually resulted in the death of 150 Tamils in the Cial Oya Valley and Batticola districts by Sinhalese settlers. (Sivanandan. 1984. p. 13) In 1958 following the wave of protest and the failure of the Bandaranaike-Chelvanayakam Pact the leckeral Party again planned a satyragraha at its party convention in Vavuniya in the Northern Province Violence again flared when a train was derailed that was suppoxedly carrying Tamil delegates. The violence this time spread beyond the immediale area lo colombo and Batticola. Wriggins (196(1) describes the violence that ensued. The troubles and violence. he writes, began on May 23 spreading rapidly to Colombo where gangs roanked Tamil districts setting fire to homes, cars and businesses. Individual Tamils were attacked. humiliated and beaten and many were subjected to torture or killed outrightly. After three days of disorder, the "s-ime Minister urged calm bui a reference to the death of a prominent Sinhalese in Batticola incensed the masses more and the riots grew in intensity.

On May 27 the PM finally called a state of emergency. Wriggins concludes:

The readiness of political leaders to use these frustrations as a means of eniisting interest group support to obtain a rural political following, and the efforts of Tamil politicians to outbid one another as "defenders of the Tamils" sharpened communal tensions still further....In the event, the majority community succeeded in obtaining the language reform legislation its ardent pokesmen sought. The alarming riots of 1958 , unparalled in the island's history, were the direct result of these reforms and of government reluctance to insist that public order be maintained and individuals protected. The memory of these events will retard the creation of a unified, modern nation state commanding the allegiance of all communities. (Wriggins, 1960, p. 270) 
The years 1956-196.5 marked the excalation of the Sri Lankan conflict to Stage Two with mounting evidence of a massive shift of social control away from the previous unitarian state. Amidst the rising tensions of 1956 each community became more isolated. Both Tamil and Sinhalese politicians sought to use ethnic nationalism to increase group solidarity. Their success in this regard was apparent in the results of the 1956 elections in which Bandaranaike won 51 out of the 95 seats. The Tamil Federal Party gained most of the Tamil votes and the UNP was decimated gaining only eight seats.(Ponnambalam, IUX3. p. 9x)

As the political landscape changed from a potentially national form of identity to an ethnic form. leaders of the communal groups were able to exercise more control of the values. aspirations and the sentiments of their constituencies. The Bhikkus had made an entrance into politic's and througn traditiona! influence had carried most of the village vote 1o Bandaranaike's party in the expectation of power and patronage. In the struggle for social control within the Sinhalese community both Bandaranaike governments and the UNP had ceded to religious pressure by agreeing to carry the banner of Sinhalese only.

Subsequent legislation by the SLPF government continued to attempt to make use of the potential reserve of social control within the new cultural landscape and at the same time force the Tamil community into accepting the new vision for Sri Lanka. The language and education legislation was a clear effort to force Christians and Tamils to bellave according to the new rules espoused by the Sinhalese majority and championed by Sushale' $x$ political elites and religious zealots. These efforts to increase social control 
under the banner of Sinhalese nationalism had significant human rights impact. The language act and the xhools takeover were a sure indication that Sinhalexe chauvinists within the government were prepared to trample over weak constitutional protections to achieve their goal. As K.M. De Silva notes, hoth the language act and the schools takeover were able to bypass constitutional provisions by framing the kegislation in such a way that it was discrimination in fact but not by law because in its written form the changes and restrictions were being applied to all sections of the community rather than one. (K.M. de Silva, 1976, p. 92)

The riots of 1956 and 1958 were also an indication that the SI.PF: once it had utilized Sinhalese nationalist language and religious : :ntimemts for election purposes found it hard to control the population's hostility towards the Tamils. The inability or unwillingness of police to bring the 1958 riots under control is the surest indication that the government either had little control over its security forces, or its population, and despite the government's best efforts, social control had been fractionalized. Although there is no evidence that Sinhalese chauvinists within the police force intentionally allowed the riots to occur in 1958, the riots were the first indication of a pattern that was to surface more forcefully in the 1970 's and 1983 .

Within Jaffna increasing exercise of social control among the Tamils was manifested into demands for autonomy and political protest. Albeit for negotiations, the demands revealed the growing anticipation that ethnic autonomy was the only alteriative to costly assimilation under Sinhalese nationalism. The germination of the idea for a separate state had not yet been transformed into an armed struggle but the foundation was 
laid.

In conclusion, we can cautiously note that a pattern in the struggle for social control and human rights abuse had begun to emerge. A new constellation of social organizations were making their mark on the political scene and the state was caught between ceding to religious pressure with all its incumbent risks, in terms of social control. or ignoring the pressure which carried even more risk. Patterns of behaviour that became visible in the mid 1950's were to be repeated over the next two decades where the costs became more horrific.

\section{Part V: UNP Recunciliation 1965-1970: An Attempt to Return to Stape One}

The election of 1965 brought the UNP back to power for five years. Under the leadership of Dudley Senanyake who had reentered politics, the UNP attempted to reconcile the competing groups but it quickly became apparent that this was impossible under the new coalition of forces created during the Bandaranaike years. When he tried to set up district councils to answer the Tamils' calls for greater autonomy he was met with virulent opposition within his own party and eventually abandoned the idea. Senanyake was successful however in retracting the proposal for a dual electoral list.

From our perspective the five-year interval was remarkable in the absence of island-wide riots or discriminatory legislation but very little was achieved that could have returned the island back to the pre-Bandaranaike period. Both the language and school's legislation remained in place and island politics entered into a sort of five-year catalepsy hefore the tumultuous period that was to follow. At the very least, the period revealed 
how difficult it was to reverse the vertical communal fomation and alliances of social control that had been allowed to ociur.

Part VI: Systemic Discrimination, Worsening Human Riphts Abuse and the Emergence of Armed Oppusition, 1970-1977: Stape Three

The reelection of Sirimavo Bandaranaike and the (Inited Front coalition in I1970) consolidated the discrimination against the Tamils. With the continued influence of Kandyans, of which Mrs. Bandaranaike was one, discrimination against the Plantation Tamils was also more extreme. There was a continuation of statc policies diesigned to increase social control by appealing to communal antagonisms and further efforts to force Sri Lankan Tamils and Plantarion Tamils to the accept the new vision of the island. These efforts were in the form of constitutional revision. educational policy changes and statc treatment of the Plantation Tamils. Concurrently we also see the failure of Sirimavo Bandaranaike to prevent dispersion of social control to other power centres within the Sinhalese community and to cabinet ministers within her government. Fividence of thex: drifts were in the treatment of government ministries as individual fiefdoms by certain ministers and a series of riots that rocked the country and led to a state of emergency from 1971-1977.

The early 1970's also heralded the beginning of armed insurrection against the state. Ironically this came first in 1971 from disenfranchised and disillusioned Sirihalese youth in the south of Sri Lanka. Although the Janatha Vimkuth Peramuna (JVP) were the first to oppose the state by force Tamil youths also began organizing in 1973 for armed 
insurrection. Withın the Tamil community, the coalescence of forces and the augmentation of Tamil social control under Tamil nationalism became more intense resulting in the formation of the separatist Tamil United Liberation Front. Finally, the effect of language legivlation and increasing communal hostility had transformed the military and security forces from a relatively ineffectual force to an ethnic army staffed overwhelmingly by Sinhalese.

The Republican Constitution of 1972 was the best indication of the SLPI's efforts Io obtain greater control over the destiny of the island and by implication over the Tamils. By 1970 , under the system of electoral demarcation, the Sinhalese controlled 80 per cent of the seats even though they made up only 71 per cent of the population. (K.M. de Silva, 1976. p. 97) Most crucial for the intercommunal relations was the change in the secular nature of the state and the exclusion of a chapter on fundamental freedom: in the 1972 C'onstitution that would have protected the minorities. Says K.M. oe Silva, the new constitution contained a chapter on fundamental freedoms but their content was practically nullified by all the restrictions. By 1966, Clause 29(2) of the Soulbury Constitution had been deemed an entrenched clause but "it was well known that the new government had resorted to the device of a new constitution partly at least because it afforded a means of eliminating clause 29(2)." (K.M. de Silva, 1976, p. 97)

The new constitution stated that the Republic of Sri Lanka would put Buddhism in a "foremost" position and obligate the state to protect and foster Buddhism. With this Sri Lanka ceased to be a secular state and to the Tamils, the special status of Buddhism 
was a clear act of discrimination. The adoption of the new Republican Constitution in May 1972 thus became the critical starting point for a neu phase in communal antagonism.

Arguing that the new Constitution entrenched their status as second class citi/ens both in terms of the undefinable status of the Tamil language and new changes to religious status, the constitutional debate al:o brought together the Iwo main Tamil parties, the Federal Party and the Tamil Congress for the first time since 1949. The Constitutional discussion also brought the Ceylon Workers (ongress into a political alliance with the Sri Lankan Tamils for the first time. Together they formed the lamil United Front--later to be called TULF--which supported the idea of a separate state. The new party also gained the support from an increasing number of Northern Tamils and led to a growing association between the Jaffna community and Tamil Nadu, thus fullilling the worst nightmare of the Sinhalese.

A second policy that was also to have an impact on Tamil-Sinhalese relations and growing frustration among Tamil youth was a change in the university enrolment procedures. In 1970, a Muslim Minister of Education succeeded in introducing a form of standardization in enrolment examinations. The effect was to place the Tamils at an extreme disadvantage which was especially important since they were heavily dependent on state employment and the professions. By the 1970's the switch in education from English to Tamil and Sinhalese had been completed but the question of university entrance requirements and a perception among Sinhalese of an unfair advantage enjoycal by the Tanniis came to a head after the election when it was rumoured that I(n) of $1(x)$ 

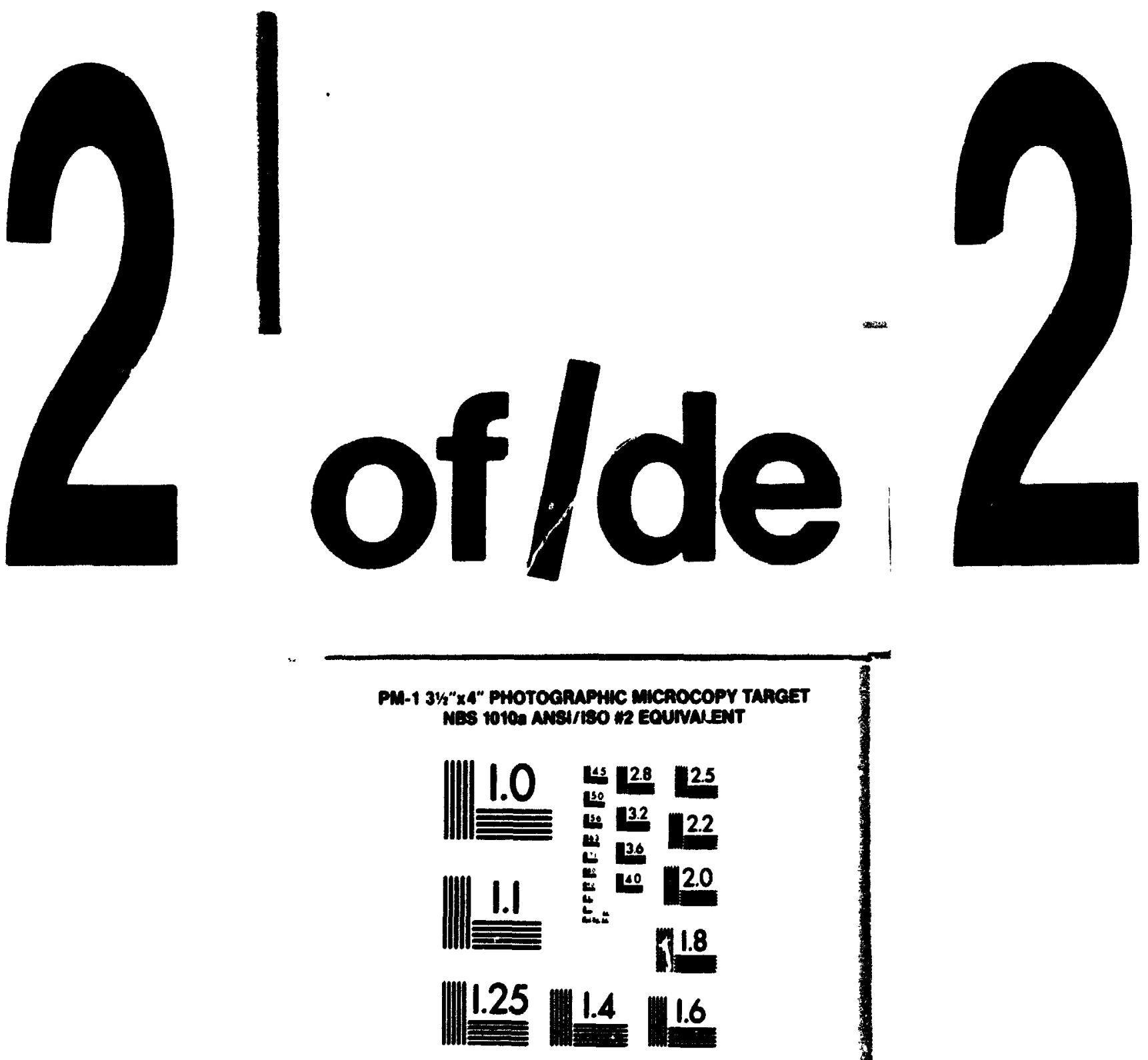

PAECHBONM RESOUUTION TARCETS

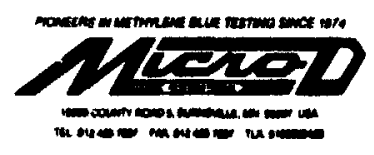


candidates selected for engineering courses were Tamils. (C.R. de Silva. 1979; While complaints about selection procedures were not uncommon this unsuhstantiated claim precipitated the introduction of a process called standardisation under which the Sinhalese were to able to obtain university entrance with lower marks. The standardization process produced an uproar which the government found difficult to defend especially since after its implementation there were only limited improvements in the number of successful Sinhalese students. (C.R. De Silva, 1979, p. 487).

...the real significance of the move, however did not lie in thesc figures. For the first time, owing to Sinhalese pressure, including a threat of violence in the universities, was successful [sic] in forcing the government to abandon 'open competition' and to introduce a system of weightage for the performance of different groups of candidates at public examinations. (C.R. De Silva, 1979, p. 487)

Despite the failure of the weightage system to significantly improve the success of Sinhalese students, the government was far too aware of Sinhalese pressure to go back to open competition. Over the next four years they tried a variety of schemes in the search for a more "acceptable and defensible" system. In 1973 it was standardization which reduced marks in all language media to a uniform sciale so that in the end the number of students qualifying from each medium would be proportionate to the number sitting the examination. In 1974 a system of standardization and district quotas with modifications was introduced. District quotas allocated vacant university places according to the percentage of the total resident population in that district. Separate quotas were also set for different disciplines. In 1975 the system was a combination of standardization with a $100 \%$ district quotas and finally in 1976 the government opted for a complicated system 
by which $70 \%$ of the places were awarded on the basis of marks and $30 \%$ by district quotas with half the district quotas reserved for backward areas.

Most significant was that in about every case the change of admissions procedure, says C.R. de Silva, was due not to educational reasons but to political pressure from various groups. (C.R. de Silva, 1979, p. 488) In each case the system also neutralized the performance of the Tamils. Under standardization they required higher marks, under quotas, except in areas where their population predominated, they were swamped by Sinhalese numbers. The later system of partial standardization and district quotas was supposed reduce the tendency of youths to migrate to urban centres in order to secure a university place. It was also supposed to provide impetus to improve rural schools, give greater opportunities for rural youth and produce more nationally minded academia who would resist the brain drain but as C.R. de Silva states the positive effects were, and still are, difficult to substantiate.

To fully appreciate the impact of the changes in educational policy one must be aware of the fierce competition for university places in all sectors of society. Robert Kearney (1975) for example notes that the number of candidates sitting for ' $O$ ' levels in Sri Lanka climbed from 53,000 in 1952 to more than 314,000 in 1967 (Kearney, 1975, p. 729) The number of students who received university degrees also rocketed from 533 in 1959 to a peak of 4,614 in 1968 (Kearney, 1975, p. 732). Equally important for those Tamils hoping to find jobs in the professions was the unemployment rate which had climbed from 34()$,()(x)(10.5 \%$ of the labour force) in $1969 / 60$ to about $546,000(13.9 \%)$ by 19697 (). For the 15-24 year-old age group the unemployment rate for those who had 
reached ' $O$ ' levels was twice as high as those who had completed only a primary education. (Kearney, 1975, p. 735) Kearney completes the picture by stating:

It is not difficult to imagine the consternation and despair of a youth who, after completing an education that had always in the past led to employment as a clerk or school teacher, is advised to return to the mud of his father's paddy field. Even this prospect might not be open. The family plot may have been sold or given to his less-educated older brothers since his education was presumed to have removed him from dependence on agriculture. (Kearney, 1975, p. 737)

Another area of conflict between the two communities, and of great concern to the

Tamils, was the colonization of state-sponsored irrigation projects which drew Sinhalese from the overcrowded Southwest and central regions of the island to the North Central region. The gradual shift northward of the frontier led to fears that traditional Tamil areas were being populated by the Sinhalese to expand their control over the island. It has been difficult to get exact population figures on the irrigation colonization schemes (Leary. 1981) but Tamil claims of discrimination asserted they were not given equal opportunity to settle in these areas compared to the Sinhalese and that non-Sinhalese syuatters received preferable treatment compared to non-Sinhalese syuatters. ${ }^{\text {In }}$

While the constitutional changes and the educational policy revisions were examples of government attempts to increase social control, one area where it became increasing clear that Sirimavo Bandaranaike was failing to exercise social control over elements within the government was the treatment of Estate Tamils by some of her cabinet ministers. In 1974, further negotiations with the Government of India settled the

\footnotetext{
${ }^{18}$ See article by David Gillies (1989 on the impact that setulement ratios had on a Canadian aid project in the Mahaweli irrigation scheme. "Principled Intervention: Canadian Aid. Human Rights and the Sri Lankan conflict." Paper presented to the Aid As Peacemaker Seminar, Parliamentary Centre for Foreign Affairs and Foreign Trade. Olawa, Nov. 27-28, 1989
} 
citizenship question for the remainder of the 150,000 Estate Tamils who had been excluded from the 1964 pact. The agreement was to allow half the group to be given Sri Lankan citizenship while the other half were offered Indian citizenship. ${ }^{19}$ Agreement that at least half of the remaining stateless Estate Tamils were entitled to be treated as equal Sri Lankan citizens however did not seem to affect some Kandyan cabinet ministers, such as the Minister of Agriculture, Hector Kobbekaduwa, who expressed racist sentiments towards Indians on more than one occasion ano followed up speeches with blatant discrimination. For example, during the period while the United Front was pursuing a nationalizing policy he used his authority to take over almost all of the plantations owned by opponent political activists before the Land reform Act of 1972 which put a ceiling on landholdings.(K.M. de Silva, 1976, p. 103) Once plantations were taken over, says K.M. de Silva, experienced and skilled managerial and technical staff were dismissed and replaced with Sinhalese political appointees. (K.M. de Silva, 1976, p. 103)

Following the Land Reform Act the two government ministries dealing with the plantations and their workers continued dramatically opposite policies. Under the Ministry of Plantations, when estates came under control there was little if any displacement of Indian workers. The workers were allowed, for example, to continue their trade union activity. In contrast, in plantations controlled by the Ministry of Agriculture there was summary dismissal of workers, expulsion from homes and workers were deprived of the right to claim benefits from the Employees Provident Fund. (K.M. De Silva, 1976, p.

\footnotetext{
${ }^{10}$ Acicording 10 K.M. De Silva (1986) there were still between 50,000 and 75,000 stateless Tamils left over who were mox included in the agnement.
} 
103). Coupled with state pressure the plantation workers also faced extreme economic pressures. Shifts in international tea prices led to rising starvation and infant mortality. Even the more enterprising among the Plantation Tamils who left the plantations and moved into squatter positions in the Eastern provinces also faced government hostility. In 1973, 400) displaced workers, all citizens of Sri Lanka, were removed by the government under emergency legislation while the province accommodated thousands of Sinhalese squatters. (K.M. De Silva, 1976, p. 105)

By the 1980's it was clear that ethnic hostility had increased as a result of increasingly discriminatory government legislation. The new heights of intercommunal hostility were best emphasized in the choice of Tamil parties to abandon attempts at negotiated settlement and become increasingly militant. The call for political autonomy in the Tamil regions became more strident and the Tamil youth who were the most affected by all the changes took to political violence and assassination of suspected government collaborators. In the 1980's the Tamil youth made up a sizeable proportion of the Tamil community (Kearney, 1975) and they were by far the most militant agitators for separatism. As they increasingly turned to violence the state responded with increasing its military presence. In a classic escalation pattern the adversarial encounters led to reactive attacks by Sinhala groups on Tamils living in Sinhala areas and Tamil attacks on Sinhalese civilians living in areas close to Tamil territory.

A factor in the increasing tension between Tamils and Sinhalese, especially in the Northern provinces, was the gradual transformation of the security forces and police. The increasing radicalization of politics in the Jaffna Peninsula had reduced any inclination 
among Tamils to associate with the police forces. Openings in the forces were increasingly filled by Sinhalese officers since the government perceived Tamils as unreliable. (K.M. De Silva, 1986, p. 269) Thus the police officers in Jaffna became overwhelmingly Sinhalese and were for the most part unable to speak Tamil which only widened the gulf. Once violence, and bank robberies occurred, the security forces were met with silence which frustrated them even further. As a result of the security forces ambiguous position and the Tamil perception of them as an army of occupation, the security forces eventually came to behave like an army of occupation.

In 1971 the state also faced another threat to its degree of social control over the island's populations. This threat came not from the Tamil community but disillusioned Sinhalese youth. Formed in 1967, the JVP (Janatha Vimukthi Peramuna or People's Liberation Front) was a tiny group of extreme left-wing Maoist guerillas made up of mostly unemployed, middle-class Sinhalese youth. (Kearney, 1975) Operating from secret jungle camps the JVP began by collecting arms, carrying out military training, pursuing political indoctrination and terrorising local villages. Its goal, according its captured leader Rohana Wijeweera, was to cause enough chaos that its armed forces would eventualiy be able to seize control in the name of socialism.

It is unclear exactly when the govemment was aware of the JVP threat since both Dudley Senanayake and Sirimavo Bandaranaike kept the organization under police surveillance. In 1967 and 1969 a Ministry of Defense report was prepared on the organization and its potential threat to the state. In another indication of the government's weakening control over its own institutions the report was not made available to the 
responsible Minister. (0'Ballance, 1989, p. 7) Whatever the reasons for the lack of communication, the armed forces were clearly caught flatfooted in April 1971 when the JVP launched an attack against the establishment. Going on the offensive in the first week of April, JVP militants took over police stations, occupied some territory in the south and attempted to take over part of Colombo. Within the first three days the army was overpowered and had difficulty controlling the spread of violence. On April 6 the Prime Minister proscribed the JVP, ordered a curfew and closed down universities. By the end of the week the army had recovered and was clearing the JVP out of the capital and regional towns. The military effort to capture or destroy the JVP continued for at least two months after with a ferocity ${ }^{20}$ that caused concern to human rights groups such as Amnesty International. The government later offered amnesties to the JVP youth but a state of energency that was instituted in 1971 continued until 1977 when the JVP political detainees including Wijeera were released for the 1977 election.

By 1977 the situation in Sri Lanka had changed substantially from the balance of forces that D.S. Senanayake had worked hard to construct in the immediate post Independence period. Following two terms of SLPF government whatever remained of the pluralist coalition between Tamil and Sinhalese parties had long since disintegrated. The fractionalization and dispersion of social control both within and away from the state

\footnotetext{
${ }^{20}$ Official estimates of the death will was $1,2(X)$ deaths and $14 .(X)(x)$ arrests but the unoficial death toll placed the number closer to 6,000 or more. See Pfaffenberger, B., (1991) Ethnic Conflict and Youth Insurgcncy in Sri Lanka: the Social Origins of Tanil Separatism. In J. Montville (Ed) Confict and Peacemaking in Multicthnic Suxicties. Lexington. Mass.. Lexinglon Boxks. p. 254
} 
becarne more obvious. Equally apparent were government attempts to maintain social control by implementing policies designed to appease Sinhalese nationalists but which had the impact of abusing some fundamental rights of the Tamil community. Pursuit of discriminatory policies had also pushed the Tamil community increasingly to the edges of the Sinhalese nationalist state structure and more into the hands of extreme separatists with their own concepts of social control.

In a startling description of a Prime Minister who had lost all touch with her constituents, James Manor describes how Sirimavo Bandaranaike became driven by paranoia following the 1971 JVP insurrection and came to rely extensively on an inner circle of associates who were predominantly of similar Kandyan background.

The collapse of discipline and the growth of corruption within the SLPF was a direct result of Mrs. Bandaranaike's mounting paranoia after the abortive insurrection of 1971. She turned inward and came to depend to a degree unprecedented in the experience of any Prime Minister upon a circle of people who she knew on a face-to-face basis. These confidants were overwhelmingly Kandyans of her own caste, including a very large number of her own relatives....Mrs. Bandaranaike's inner circle isolated itself increasingly from information and influence passing up through the party.... The govemment's reform programmes, which had raised such high hopes, were used increasingly by the high command to settle scores-often according to whim in defiance of any ideological or partisan logic. In this unhinged atmosphere, what organization the SLPF had in 1970 disintegrated, its power base narrowed and the election of 1977 brought disaster.(Manor, 1979, p. 35)

The fact that Sirimavo Bandaranaike had withdrawn into an circle of close confidants of similar caste merely supports other indications that the SLPF had lost touch with the population and thus the social control it had been attempting to garner. In the period of her government's tenure the state had been rocked by serious riots in 1958 and continuing 
"brushfire" communal tension. The 1971 JVP insurrection had. according to many authors, come as a surprise to the government. The insurrection itself was a sign that a substantial part of the Sinhalese no longer concurred with the values and vision espoused by the government. Bryan Pfaffenberger for example reinforces this observation when he notes that increasing unemployment and suspicion had alienated the youth from the political establishment.

Not surprisingly, Sri Lankan youths during the late 196()$^{\circ}$ 's and 197(1's came to feel that their interests were not being looked after by the existing political leadership, the politicians of the established political parties. who were increasingly viewed as utterly corrupt - indeed. irredeemably corrupt. Not only had this leadership failed to provide Sinhalese youth with jobs, but also it was significantly older than the population as a whole, a mark of suspicion in the eyes of youth. (Pfaffenberger, 1991, p. 253-254)

The activities of her ministers especially the different policies between the Minister of Plantations and the Minister of Agriculture also suggests growing dissipation of social control within the state apparatus. The treatment of individual ministries as centres of power was a classic example of the rise of Midgal's 'strongmen' within the state apparatus and a sure sign that Mrs. Bandaranaike was facing a challenge for social control from within her own government. The final indication of the government's problems in exercising social control came after the 1977 elections when riots again broke out all over the island and were attributed by many observers to the pressures that had been building up over the last two decades.

Matching the SLPF loss of control was an equally dramatic shift of greater social 
control to the Tamil community. The fact that the new belief and value structure was being accepted by a growing number of Tamils can be seen in the shift of Tamil politics away from negotiation to the formation of a party with a specific mandate for separation. The extent of support for a Tamil community invested with a larger degree of social control was further undersicored by the TULF's decision to make separatism the platform of its campaign in the 1977 elections. By 1977 Tamil youth separatists had also begun to be the driving force behind Tamil politics and their flat rejection of the existing system of Sinhalese dominance was being accepted a large number of Tami" youth. While the impetus began in 1977 it was not until the late 1980 's before the Tamil Tigers could really exercise extensive social and political control over the Jaffna peninsula. The gradual increase in leadership by the Tigers--by 1980 the TULF politicians had ceded to them-was also an indication that the moderates had been replaced by youthful extremists. Again this was not entirely due to political circumstances but also the death of several Tamil politicians who had previously exercised moderation in their dealings with the Sinhalese. In the mid-197(1)'s the Tamil community lost three of its esteemed and experienced politicians including S.J.V. Chelvanayakam, who was very much the father-figure of Tamil politicis and had negotiated the aborted Bandaranaike-Chelvanayakam Pact. The Tamils alson lost C.G. Ponnambalam who had led Tamil politics up to 1956 when Chelvanayakam became the foremost leader and $M$. Tiruchelvam the only TULF politician with any experience in cabinet. Thus by the late 1970's TULF was being led by an insecure and inexperienced leadership. In similar fashion to the 1930's when the youth cajoled Tamil politicians of the day to boycott state council elections forcing senior 
Tamils into a nonnegotiable position, the youth of 1977 had also forced senior politicians into a more aggressive and less moderate position from which it could take many more years to reverse. (K.M. de Silva, 1986, p. 291) 


\section{CHAYTHK FIVE: ESCALATION TO STACE FOUR, 1977 - 1983}

\section{Part I: The Return of the UNP and Failed Attempts at Reconiliation}

In 1977 the UNP, under the leadership of Junius Richard Jayewardene, swept to power. While the election at first marked the beginning of an attempt at reconciliation, the island-wide riots that occurred in the post election period were a token of things to come. Under new leadership the character of the struggle between Sinhalese and Tamil shifted. It became more complicated and more violent. Like the SLFP period where we see a fractionalization of the struggle for social control within the government, in the Jayewardene period it becomes more pronounced with factions inside the government reportedly working to undermine the efforts of Jayewardene to resolve the conflict. Evidence of a struggle between Jayewardene, on the one hand, and Sinhalese nationalists such as Cyril Mathew on the other, become more visible. The extent of social control that had drifted to extreme nationalists like Mathew also become more visible in the activities of an organization called the J.S.S. (Jatika Sevaka Sangamaya, National Workers Organization) The changing character of the struggle for social control also produced a change in the character of human rights abuse. Instead of discriminatory legislation being the predominant form of abuse, this time it appears the worst atrocities were encouraged by factions within the government or were a result of indiscipline and lack of control within the security forces.

The riots that immediately followed the elections of 1977 began with a clash 
between police and a section of the Jaffna population. It precipitated an outbreak of communal violence between the Sinhalese and ' amils in mid-August which spread to many parts of the island and was reminiscent of the ethnic disturbances of the mid1950's. When it was over an official government commission, the Sansoni Report. estimated 1(K) people had died. While most observers agree the report probably erred on the side of caution, the Tamil Refugee Rehabilitation Organization reported that $14,(\mathrm{XX})$ refugees had been through its camps and 2,(0) Tamil families from the South had scught sanctuary in the north and east provinces. (Schwarz, 1986, p. 8) The violence was according to a report in The Guardian, (27 August, 1977) attributed to disgruntled SI.PF leaders who saw an opportunity to embarrass the government: With the assistance of political appointees and local gangsters the desposed SLPF members were reported to have organized and encouraged the attacks on Tamils. (cited in Schwarz, 1986, p. II) Unlike previous riots, in the 1977 riots Estate Tamils were for the first time subjected to mob violence. (Sivanadan, 1984, p. 28)

The riots indeed were an inauspicious beginning for J.R. Jayewardene who had come to power promising change and reconciliation. The all-party conference which Jayewardene had planned to hold to begin the healing process failed to take place. It was the absence of dialogue that was the real tragedy, but by 1977 the avenues for communication and reconciliation were few. Walter Schwarz, of The Minority Rights Group writes;

The demand for separate statehood could well be interpreted, even now, as an extreme form of what the majority of Tamils really want: a reasonable autonomy in running their own administration, security from fear of being 'over-run' and 
placed in a minority in their "own' areas through colonization projects and a fair share of economic and educational opportunity. (Schwarz, 1986, p. 11)

To Jayewardene's credit, it appeared that he was intent on attempting to resolve the conflict. Three points of reconciliation named in the UNP election manifesto included improved protection for the minorities in the constitution, a reference to administrative decentralization to the village level with District Development Councils and a promise to remedy Tamil concerns in education, colonization, the use of the Tamil Language and employment in the public and semi-public sectors. An all-party conference was supposed to deliberate on ways to implement the UNP election promises. With the resounding defeat of the SLFP in the election however, the TULF was put in the interesting position of forming the official opposition and its leader, A. Amirthalingham, immediately made it known that the party was not renouncing its separatist aspirations. The TULF refused to attend committee meetings on the new proposed constitution, which offered more to the Tamil community than anything since the Bandaranaike-Chelvanyalkam Pact. In refusing to participate in the discussions Amirthalingham said,

The Republican Constitution of 1972 sought to sever the legal and constitutional link with the past. Once there is such a break in legal continuity, the sovereignty of the inhabitants of the island, until then under eclipse...resurfaced. Hence the sovereignty of the Tamil nation, which was ethnically, geographically and linguistically separate, identifiable and distinct, revived. The United National Party, had a clear, unequivocal mandate to assert the sovereignty of the Sinhala nation and enact a new constitution. The mandate of the majority of the Tamil nation pointed to a different duty. (cited in K.M. De Silva, 1986, p. 294)

If nothing else this missed oppurtunity at potential reconciliation was evidence of just how far radicalization of Jaffna politics had gone. 
Besides changing the structure of government to a presidential system with American and French features, the 1978 Constitution kept the Prime Minister and Cabinet form of government but changed the electoral system to proportional representation. The new electoral system was supposed to make it difficult for any one party or coalition to achieve a two-thirds majority and amend the constitution. It was intended to be an assurance of sorts for the continued protection of minorities. The new cotistitution also kept Sinhalese as the official language but elevated Tamil to a national language, and clearly codified a list of fundamental rights. Protection of the fundamental rights which included freedom from discrimination on the ground of race, religion, caste, sex political opinion or place of birth were made stronger through provisions that included protection through the Supreme Court. The state's role with regard to Buddhism remained the same.(K.M. de Silva, 1986, p. 295)

The centrepiece of the government's effort at reconciliation were the District Development Councils (DDC). Although the DDC's were not a change to the essential character of the unitary atate they were supposed to be a decentralization of administrative services. It was not until 1979 against imminent eruption of ethnic hostilities that the government turned its attention to the DDC's. In 1981, elections were held in Jaffna but from the start there were complaints that the councils did not have enough money nor decision-making authority to do anything substantial since Colombo-based politicians were reluctant to give up any power.(Jeyaratnam Wilson, 1988)

Some of the other gestures in the Constitution proposed changes in University admissions but by mid-1978 the $v$ 'e question was once more embroiled in controversy. 
Some of the more substantial changes were directed at the Plantation Indians. Unlike the TULF, which boycotted the constitutional talks, the Ceylon Workers Congress (CWC) joined the Parliamentary committee on the constitution and managed to win several concessions including extension of many of the fundamental rights to stateless Indians, elimination of the distinction of citizenship by descent and freedom for plantation Indians to vote in local elections. Members of the CWC were also appointed to sit on directorates of the two state corporations that controlled the nationalized plantations. This enabled the Indians to have an influence over their affairs and some of their initiatives led to improvement in welfare, housing and education on the plantations.

Despite political efforts. events in Jaffna had led to a steady growth of guerilla actions. In 1976, robberies and bank holdups were increasing and in 1978 the Liberation Tigers of Tamil Elaam, estimated to have a following of around 200 youths, had emerged, claiming responsibility for 11 killings starting with the murder of the mayor of Jaffna. With the increase of violence, tension also arose between Jaffna residents and the iocal security forces with both sides claiming atrocities. ${ }^{21}$ Continued violence in Jaffna in 1979 led the government to impose emergency regulations under the Public Security Act in July 1979. Special security arrangements were made with the appointment of Brigadier Weertunge to wipe out terrorism within six months. (Sivandan, 1984: Murray, 1984). The Tamils viewed the special security arrangements as a virtual military occupation. The government also enacted the Prevention of Terrorism Act (Temporary Provisions) 1979. The act was roundly condemned by international observers including Amnesty

\footnotetext{
"Many authors, including Virginia Leary. (1981) in her report to the International Commission of Jurists, point out that at the beginning the Tigers were not a large force.
} 
International and the International Commission of Jursts. The act which violated the 1982 constitution on several grounds gave the state the power to arrest and detain, in incommunicado for up to 18 months, anyone remotely suspected of unlawful activity. The act was also made retroactive which meant individuals could be held for offenses that had occurred before or after the passage of the bill. Statements given under torture were also made admissible in courts without juries and on conviction the death penalty could be prescribed. The act also gave the police the power to enter any premises without permit. One significant aspect of the act was the inclusion of communal incitement as an offense punishable by imprisonment. Virginia Leary, in a 1981 report to the International Commission of Jurists wrote:

The provisions of the Sri Lankan Terrorism Act are not only objectionable from a human rights point of view but it is doubtful that the act is effective in controlling terrorism. The limitations on human rights...does not seem acceptable as a necessary means of maintaining public security. (Leary, 1981, p. 55)

Other authors go further in condemning Jayewardene's decision to resont to the security forces and extraordinary emergency legislation. Says A. Sivanadan, the PTA combined the worst features of both the British and South African Acts.

At the end of the six months, the spectre of terrorism that Mathew and Co. had summoned up and the President had sent troops to wipe out had been made flesh by the army and provoked counterviolence of the Tamil youth. From now on it was war against the state and its occupying army. (Sivanadan, 1984, p. 31)

The more extremist acc ınts of the PTA, like Sivanadan's, ascribe the President's resolt to the PTA as a result of paranoia that had been whipped up by the government controlled 
press in which any event that had violent tones, such as bank robberies, were made to appear as terrorism. Whether they accurately portrayed events or not, it seems clear that the military response and PTA were heavy measures indeed to disarm and control a group that had been estimated at 200 strong.

In 1982/83, despite attempts at reconciliation in some areas of long lasting dispute between the Tamils and Sinhalese, the government also implemented several decisions which were not directed at the Tamils but certainly marked a divergence from usual democratic practice. The momentous changes occurred in two phases; the first came in the last five months of 1982 with the popular election of a powerful executive president. The election was the first time Jayewardene had gone to polls although he made himself president in 1978 through constitutional change. The second dramatic event was the subsequent decision of the ruling party not to hold the parliamentary elections that had been scheduled for 1983. Instead, the government used a referendum in December 1982 to ask the electorate if they could stay in power for another six years. The referendum and this course of action was approved by only 54.66 per cent but the government went ahead despite obvious opposition. (C.R. De Silva, 1984, p. 46) The referendum was matched, according to some observers, with blatent lawless and draconian treatment of the oppo:ition.

The reason given for the referendum came soon after the presidential election when Jayewardene announced that he had information that one faction of the SI.FP had decided to assassinate him and a few other ministers, abolish the Constitution and imprison Mrs. Bandaranaike. However, as C. R. De Silva reports, very little evidence has 
since come to light to support the claim that such a plot, which became called the "Naxalite plot," ever existed. More than likely, he states, the amendment was primarily a way to maintain the government's five-sixths majority for another six years and thus alter the Constitution at will. Like other observers, C. R. De Silva, expresses more concern over several "undemocratic" aspects of the referendum campaign, in particular, the detention of various opposition organizers, the sealing of opposition presses and the use of force to intimidate the opposition. He concludes:

...the intimidation and impersonation and other undue uses of state power were significant in some areas during the referendum, and although it may not have affected the final outcome, it strengthens an unhealthy trend towards interference with democratic processes. (C.R. De Silva, 1984, p 47)

Other observers, some of whom used pseudonyms to protect their identity were much more severe in their criticism. Priya Samarakone ascribes the so-called Naxalite plot to little more than intraparty squabbles within the SLPF. ${ }^{22}$ He states there was little foundation for charges in court much less evidence of a plot to assassinate the president. (Samarakone, 1984, p. 87) Calling the referendum "a massive exercise in political engineering," Samarakone states, the activities surrounding the referendum drew the validity of the results into question. He refers specifically to the continuation of a state of emergency during the campaign, illegal campaigning, harassment of key opposition personnel, attacks by toughs, police denial of meeting permits for opposition and general harassment, intimidation and impersonation. He states;

\footnotetext{
"Priya Samarakone, according to James Manor in whose book he appears, is an esteablisthed schotar who had "compelling" reasons for anonymily.
} 
Political thuggery has never been wholly absent from Sri Lankan elections, but the nature and scale of this operation were unprecedented. The removal of opposition polling observers and the intimidation of public servants were entirely new phenomena. Indeed, so serious were the malpractices at the referendum that they represented a virtual dismantling of the electorate machinery and the subversion of democratic process. (Samarakone, 1984, p. 104)

He concludes;

The referendum bodes ill for the future of parliamentary democracy in Sri Lanka where it had hitherto flourished. But its implications and repercussions went far beyond the simple extension of the life of a spent Parliament. The steady undermining of respect for law and order and the feeling that illegality may be resorted to with impunity by those having the right political connections reached an unprecedented height during the referendum. (Samarakone, 1984, p. 112)

\section{Part 1l: The July 1963 Riots}

The seciond dramatic development in 1983 was a serious outbreak of violence which consisted almost entirely of attacks by the Sinhalese majority on the Tamil minority. Some believe that the violence was caused by elements in the ruling party who wanted to destabilize the ruling party in order to enhance their position in a factional struggle for control or they wanted to embitter the relations between the two ethnic groups in order to promote Sinhalese hegemony. The events of 1983 aside for the moment, by late 1982 many observers, especially the Tamils had concluded that the three previously mentioned gestures of UNP government had come to nought. Sinhalese chauvinists, describes Manor (1984) in the government and ruling party had blocked attempts to increase the official use of Tamil. They had also prevented any decentralization of power to the District Development Councils. Furthermore, he states, Tamils were particularly embittered by the "harsh and undisciplined behaviour" of the security forces in the Jaffna district. Police action frequently took the form of riots, 
murder or lawless acts which were designed to insult the Tamils. In 1981. for example. after a scuffle at a fairground in Jaffna involving off-duty policemen, police rioted and killed several Tamils. In 1981 security forces also rioted in reaction to attacks by Tamils Tigers and burned the Jaffna Public Library which contained precious Tamil manuscripts. The Plantation Tamils were the worst hit by both the 1977 and 1981 riots and after both outbreaks migrated in large numbers to the Trincomalee and Vavuniya districts. (Manor. 1984, p. 13) Amnesty International and the International Commission of Jurists also continued to report allegations of torture and rape of Tamils by the security forces in the Northern Province.

What is significant about the violence of July 1983 was the broad nature of attacks and the more visible connections to the ruling party. It was also a watershed event that marked the escalation of the conflict to Stage Four and the violence that ociurred indelibly imprinted itself on the psyche of the Tamil community. For the first time the violence in 1983 was also against Tamil professionals and entrepreneurs who were an important source of moderates.

Faced with a rising tide of violence and recrimination in July 19.83 Jayewardene called another all-party conference to discuss the Tamil problem and minority rights. At the same time the TULF was also meeting on the idea of withdrawing its M.P.s from Parliament. On the night of July 23, 1983 Tamil terrorists killed 13 Sinhalese soldiers. The bodies were brought to Colombo for burial and over the next few days riots and killings on an unprecedented level took place. Tales circulated of organized looting and pillaging being led by individuals in European suits with electoral lists. The violence was 
not stopped by the Army or Police although they were present on the streets. On the evening of July 24 th a curfew was ordered but the violence continued and spread beyond Colombo to the outskirts of the island. On July 25 perhaps the most notorious event was the murder of 37 Tamil prisoners in Weilakade Prison by Sinhalese prisoners who had gained entrance to the wing where the Tamils were housed. On the next day another 15 Tamils, who were also being held under the PTA, were killed under similar circumstances. On the third day the President finally came on television but said nothing in the way of condolences towards Tamil victims, instead sought only to appease Sinhalese fears about making concessions to the separatists. After the President appeared a succession of Ministers also appeared but none of them spoke of the degree of suffering endured by the Tamils. The next day there was a rumour of an attack on Colombo by Tamil sepuratists which spread panic throughout the city. Hysterical groups of rioters attacked and killed more innocent Tamils.

In the end the results were horrifying. The total number of dead according to government figures was $\mathbf{4 0 0}$ although other sources have estimated between 1,000 and 3,(x).(Murray, 1984, p. 106) Of the normally 162,000 Tamils normally living and working in Colombo, over 100,000 had become displaced, most of whom sought refuge in the northern province. The government formed the Rehabilitation of Properties and Industries Committee to determine the amount of damage and its economic effects. Its report. issued in late August of that year, stated at least 15,000 jobs had been lost mainly in the textile trade. approximately 118 factories had been affected although only 28 had suffered extensive damage. The overall cost of damages was estimated at U.S. $\$ 72$ 
million. (O'Ballance. 1989, p. 26)

Since the horrifying events of July 1983, there have been several attempts to explain what had happened. The government laid blame for the riots on three left-wing extremist groups: the JVP, the Nava Sama Samaja Party which was a small organization previously associated with the Trotskyist Lanka Sama Samaja Party and the pro-Soviet Communist Party. However the government's explanation has been ruled implausible by some like Eric Meyer (1984) who argue that the likelihood of co-operation on such a massive scale between parties that had never before co-operated and in a way that avoided discovery by security forces remains doubtful. (Meyer, 1984, p. 141)) Instead, he argues that the violence was a natural extension of the "lawlessness and trickery" during the referendum campaign. He advances a second theory that President Jayewardene was not as powerful as many assumed and was not able to control the Sinhalese chauvinistic forces within his party. Addressing the question of why the President was not able to bring an end to the violence, Meyer states "the only possible answer is that despite appearances, he had lost control of his party and his armed forces."(Meyer, 1984, p.142)

In searching for causes Meyer also describes the rise of a new class in Colombo which had encouraged the violence. The new 'Mudalalis' were shopkeepers and small entrepreneurs whose influence had increased steadily over the past 15 years and had created a role for themselves as the agents and political backers of political parties both in large institutions and in the provincial towns and villages. The connections of the mudalalis to the underground in smuggling and corruption was also an open secret, says 
Meyer.

The rise of this new middle class which was unconnected with the anglicised bourgeoisie in Colombo, which had enjoyed until then a monopoly on political activity, upset the rules of the game. Indifferent to the subtle principles of parliamentary democracy, seeking to impose their new authority by whatever means possible, these parvenus constituted a class which was particularly receptive to chauvinist propaganda, which recognizing it to be in their own interest, they propagated and amplified. (Meyer, 1984, p. 151)

Gananath Obeyesekere pursues a similar line of inquiry as Meyer except he points the finger of responsibility mainly at a massive organization which called itself a trade union but was actually a political "stick" that was used by the likes of Cyril Mathew, the Minister of Industry who had been expelled from the UNP for racist provocation. Obeyesekere examines several trends since the 1960 's one of which was the increase of political thugs who were linked to politicians by local level merchants. The other disturbing trends he notes were: the emasculation of the police forces at the local level through either corruption or intimidation, the institutionalization of violence since the election of the UNP and the ties between the Jatika Sevaka Sangamaya (National Workers Organization) and the government. Through a process of intimidation of other unions and an increase in membership from the 'lumpenproletariat' the JSS, says Obeyesekere, had become the biggest union in the country and had a powerful network that stretched beyond Colombo and included small market towns and villages. The union was not orientated towards the workers but actually "owed its allegiance" to party bosses. The president of the JSS was Cyril Mathew. Unlike traditional political networks where village elders determined the village vote, says Obeyesekere, political power in days of massive 
youth unemployment rested with those who controlled the disillusioned youth. It is to the JSS that Obeyesekere attributes the riots of 1983.

An analysis of events (the riots of 19831 make it equally clear that elements within their own party (UNP| forced the issue. and once urban mobs were aroused all sorts of pathological elements in the city population went on the rampage. Contrary to Tamil opinion I do not believe that the government actually organized the riots; rather it was organized for the government by forces which the government itself had created albeit for other purposes. Perhaps the government itself is still unaware that this many headed monster which it had created may destroy not only its creator but the entire democratic fabric of Sri Lanka society as well. (Obeyesekere, 1984, p. 174)

Obeyesekere was the not the only observer to notice the rise in organized gang involvement in the riots. In her 1981 report to the International Commission of Jurists, Virginia Leary too noted that unlike the violence of 1958 and 1977 , the riots of 1981 also appear to have been in part the work of organized gangs carried out in a systematic and planned way. (Leary, 1981, p. 22)

Following the riots of the 1983 Sri Lanka had well and truly entered Stage Four. After the riots many Tamils were convinced the situation had changed irrevouably and there was little chance of returning to the pre-195(1)'s period of relative peace. SinhaleseTamil relations deteriorated and the two communities beciame further estranged. After the riots President Jayewardene proscribed any organizations that espoused separatism. TULF MP's refused to sign an oath renouncing separatism and were expelled from Parliament. This had the effect of strengthening the role of the militant separatists and leaving the Tamil community without political representation. 
Conflict between the security forces and Tamil militants in the Jaffna peninsula continied with allegations of atrocities by both sides. According to Tamil sources more than $3(x)$ civilians were killed and 160,000) left the island as refugees between mid-1983 and the beginning of 1986. (Schwarz, 1986) Around 300,000 had also been displaced within the island. Amnesty International repeatedly condemned extra-judicial killings and indixcipline by security forces in the Jaffna Peninsula. In June 1984 Amnesty International also expressed great concern at the extension of powers under the PTA. In June 1983 the government passed provision 15A which allowed security forces to dispose of bodies without inquest on the pretext that it enabled greater flexibility for the security forces to combat terrorism. Amnesty International's response was outright condemnation:

By permitting disposal of dead bodies in secret and by suspending the requirement to hold inquests, the effect of Emergency Regulations 15A is to absolve members of the Armed Services from legal liability through prosecution in the courts for extra-judicial killings...and to create the impression that civilians can be killed with impunity. (Amnesty International, June 1984, p. 11)

In the Spring and Summer of 1985 violence reached yet another peak with hundreds of deaths on both sides. The most traumatic experience for the Sinhalese was the massacre of 146 civilians in Anuradhapura in May 1985. Tamils said the Anuradhapura massacre was the result of the massacre of 76 civilians at Valvetihurai. (Schwarz. 1986). Struggles between the approximately five Tamil extremists groups also (xcurred with increasing frequency until 1986 when the Tamil Tigers emerged supreme. In January 1987 the Tigers declared administrative authority in the Jaffna peninsula and in May the government responded with a major military assault on Jaffna.

Events in Sri Lanka had also caused a wave of concern in India and in 1987, India 
and Sri Lanka shocked the world by signing a peace accord. The accord made several concessions to Tamil demands including accepting Tamil as one of the official languages and political autonomy for the north and eastern provinces which had been unilaterally merged by Jayewardene. In return, the Indians agreed to send a peacekeeping force, the IPKF (Indian Peace Keeping Force), to disarm and protect the Tamils. The truce failed utterly when the Tigers reneged on the agreement and became involved with skirmishes with Indian troops. Eventually the IPKF swelled to 45,(x) troops. Over the next three years, before withdrawing completely in 1989 , the Indians lost $1,(x(x)$ troops. In response to the presence of the IPKF, the JVP again launched a terrorist campaign killing Sinhalese moderates and politicians who they claimed had sold out the island to the Tamils. The Sri Lanka government responded to the JVP's second insurrection with brutal efficiency. Using new emergency legislation the Sri Lankan security forces were reported to have summarily shot and killed demonstrators suspected of being JVP sympathizers. There were also widespread reports of vigilante groups connected to the security forces and the government although the connections were denied by the government. According to the New York Times more than 1,000 killings and reprisals had taken place within the first three weeks of October 1989. The Economist also estimated the murder rate at the height of the subversive war was more than $1(x)$ per $1(x 0)$ (The Economist, Oct. 1989, pg 38).

Since we are interested in the causes of human rights rather a description of rights abuse it is not necessary to elaborate further on Sri Lanka's slide into fullsciale civil war and the accompanying human rights abuse; they are well documented elsewhere. More 
important is to pursue our assessment of the disintegration of social control following the election of 1977 and the excalation of human rights abuse until the threshold of Stage Four in July 1983. Suffice to say that events after 1983 match our definition of stage four which was the unlimited and unrestraned use of violence. At the threshold of stage four, President Jayewardene had clearly lost control of both the security forces and elements within his own party. In his 1984 report to the International Commission of Jurists, Paul Seigart commented extensively on the lack of discipline and political control of the Sri Lankan Army. He states;

It is not in dispute that some members of the Sri Lankan armed forces have, on such occasions, got out of control, and that even their own officers have found it briefly impossible to bring them to order. That is how at least some of the now admi!:ed 51 civilians were killed by armed members of the security forces during the cunmunal violence last summer....It may take some time before discipline is fully re-established in Sri Lanka's armed forces, but it is essential that it should be. It is fundamental to the concept of any army that it should be a fully disciplined force: without that, it is no more than a dangerous armed rabble. (Siegart, 1984, p. 71)

Seigart also made similar comments on the need to discipline and train Sri Lanka's police force.

The extent to which lack of political control contributed to the violence of 1983 has also been addressed by Obeyesekere who speculated that the President was advised not to impose a curfew and use police forces to control riots because some "strong-arm lactics" by Sinhalese toughs would facilitate negotiations with the Tamils. Obeyesekere also refers to the degree of corruption and intimidation within the security forces that may have rendered them either impotent or direct supporters in the 1983 riots. While Obeyewekere's comments on the degree of corruption is corroborated elsewhere it is 
questionable that Jayewardene, who is generally respected as a man of stature, would intentionally have allowed widespread violence just to i.nprove his bargaining position.

A second more apparent aspect of the loss of social control relates to the rise of the JSS and its greater ability to manipulate the political sentiments of local villagers. The connection between lack of control over the JSS and their violation of human rights abuse seems clear. Evidently the JSS was controlled by Sinhalese chauvinists, and apparently freed from legitimate political restraint, they operated according to their own rules. The creation of a hostile rabble operating outside judicial restraint combined to make a dangerous brew out of which it would be hard to avoid human rights abuse. It is also significant that the JSS was connected to the Mudalis. Although we have not extensively examined caste politics in Sri Lanka it is important to know that since 1956 there had been rising conflict between the Kandyan Goyigama caste and the Karava caste. Thus the dispersion of soc:al control to the JSS, the Bhikku.s and the Mudalis represented a shift from allegiance among the population from the Goyigama caste to the Karavas.

Finally the connection between the loss of social control and human rights abuse becomes clear when one examines the impact of the wide ranging emergency powers under the PTA in the context of widespread indiscipline within the security forces. The combination of insufficient control over the armed forces, their general hostility to Tamils (few Sinhalese soldiers were able to speak Tamil and many resented their posting in Jaffna where they were so obviously faced with frustration and hostility) created an army that was exactly what Seigart feared most--an unrestrained, dangerous and armed rabble.

The decrease of social control from the state towards the Tamil community is 
equally apparent. Intimidated by Sinhalese chauvinism and extremist terrorism, Tamil moderates by 1983 were completely unable to exercise any restraint over events. As we have noted, the TULF in the early 1980's was led by inexperienced leaders who had allowed extremist youth to back them into an unnegotiable corner. Once committed to separatism, intimidation through violence prevented moderate leaders from acting with any degree of conciliation. Thus the removal of TULF from active political negotiation following the 1983 riots and the eventual administrative and social command of the Tigers in 1987 was the logical outcome of a trend that had begun in 1956. Finally that the social formation of society was at this point completely vertical with no bridges between either community was patently obvious. 


\section{CONCLUSION - HUMAN RIGHTS ABUSE IN SRI LANKA AND) THE}

\section{STRUGGLE FOR SOCIAL CONTROL.}

Reading the newspaper, it seems everyday one is reminded of Sri Lanka's story. Tales of struggling fledgling democracies in Eastern Europe and the former Soviet Union are unique but some of the commonalities between Yugoslavia, for example, and Sri Lanka are startling. In both cases ethnicity and ethnic nationalism once raised as a rallying cries have shown themselves to be a powerful adversaries to nation-building. This is not to argue that the process of democratization in Eastern Europe will necessarily follow the sad pattern of events in Sri Lanka. The degeneration of society into civil war and accompanying gross abuse of human rights are not inevitable fatal flaws of either ethnic heterogeneity or immature democracy. In fact the Sri Lankan study s' ows ethnic hostility was entirely a 20th Century phenomenon and entirely avoidable. S. Arasaratnam writing for Sri Lanka's prestigious Marga Institute as much says the same thing. The revival of one culture does not necessarily entail an attack on other cultures sharing the same national boundaries. He writes;

It was not inevitable...that Sinhalese communalism should come into conflict with its Tamil counterpart. A Buddhist renaissance had nothing in it that would be damaging to Hindu interests. Nor would a recognition of the Sinhala language necessarily hurt the functioning of the Tamil language. There were enough precedents in pre-European history to suggest co-existence of two cultures. But the nature of Sinhalese revivalism in the way it developed from 1954 made such coexistence impossible and conflict a necessity. (S. Arasaratnam, 1979, p. 508)

It is an explicit argument of this framework that ethnic conflict and gross human rights abuse are not inevitable. They are the compound of particular social and state 
characteristics and the result of a sequence of decisions. To be sure there are many competing theories to explain ethnic conflict. The question remains does the concept of social control help explain the events of Sri Lanka any better than other competing theories? More importantly does this framework, relying as it does on the key concept of social control, give any insight into possible causes of human rights abuse. To answer the second more important question we must begin by tackling the first.

in Chapter One we examined many of the competing theories that attempt to explain both ethnicity and ethnic conflict. Primordial theories explain ethnic conflict as a vestige of traditional antagonism that arise when social norms that keep latent hostility in check break down. Ethnic conflict in Sri Lanka would thus be considered the outcome of longstanding hostility between the Sinhalese and Tamil communities. The evidence we have considered presents a compelling argument that the conflict in Sri Lanka was not a primordial conflict: in fact it was a phenomenon which arose only when politicians appropriated linguistic nationalism as a vote-getting vehicle and implicitly forced the Tamils to decide between assimilation or struggle. The long standing cohabitation between the Sinhalese and Tamils prior to independence also suggests there was not an acute awareness of differences beiween the two cultures. The early ruling families of Sinhalese and Tamil kingdoms were close relatives and there were several examples of intermarriage and interaction. The so-called distinctions between Aryan and Dravidian races have also been questioned by anthropologists. In short Sri Lanka's problem is modern in origin.

Modernization or organizational theories on the other hand focus on ascriptive 
aspects of ethnicity arguing that individuals form ethnic groups both for reasons of personal security and material benefit: Conflict is seen as largely the result of competition for scarce resources. As Bryan Pfaffenberger (1991) suggests modernization theories are able to explain some aspects of the Sri Lankan conflict but not all. They can explain, for example, the Sinhala-only legislation and educational reform as partially economic in motivation. They can also explain the escalation of the conflict as people became increasingly frustrated with shrinking employment opportunities. As Pfaffenberger states what modernization theories can not explain is why both sides pursued the conflict beyond the point where they began to suffer economic loss. In the riots of 1983, for example, both the Tamils and Sinhalese suffered from the destruction of factories and the subsequent withholding of aid commitments by the international donor community.

Social psychological theories, such as Donald Horowitz's, can also go a long way to explain why both sides developed hostile perceptions of one another as a result of relative comparisons of self-worth. In the Sri Lanka case the colonial experience and educational advantages enjoyed by the Tamils explain the rise of linguistic nationalism among the Sinhalese and its counterpart reaction within the Tamils but it does not fully explain, at least according to Pfaffenberger, the passions of the secessionist fight by Tamil youth. Nor for that matter does social psychological theory explain the JVP insurrection or why the Sinhalese as a self-perceived backward group pursued the conflict beyond the point where connections were made with Tamil Nadu and the Indian government. Since Sinhalese self-perception as a threatened culture was dependent on seeing themselves surrounded by a potentially hostile and united Tamil culture, excalating the conflict 
beyond the point where it became a self-fulfilling prophesy also weakens this social psychological theory in the Sri Lankan case.

Pfaffenberger himself find the social psychological model most valid but prefers to explain the secessionist movement as a result of rising disaffection of the youth. Explanation that relys on the frustration of the youth as educational and employment opportunities steadily shrank is remarkably similar to TR Gurr's theory of relative deprivation. Again it explains certain aspects of the civil war especially the Tamil secessionist movement but it does not explain the JVP insurrection since the Sinhalese youth had potentially the most to gain in terms of opportunities especially during the SLPF years where opportunities in the public sector were expanding quickly for those individuals that spoke Sinhala.

So what about social control framework? How well does it explain ethnic conflict in Sri Lanka? Social control has been defined as the ability of both the state and social organizations to offer acceptable strategies of survival to individuals and groups. Survival strategies offer both a system of beliefs and symbols to answer individual needs for group identity and provide a programme to distribute material benefits. Both the state and social organizations are competing among each other to offer viable strategies of survival and therefore gain the widest currency of social coitrol. Ethnic affiliation in this framework is considered one such strategy. Within a society organized along ethnic lines competing ethnic groups offer alternate strategies to achieve a vision of society. Some groups may be more extremist than others. In the struggle that occurs a weak state may be unable to compete with other social groups to offer adequate strategies and consequently begins to 
lose social control with the result that social control becomes dispersed. As dispersion increases conflict among social groups and the state escalates. We have argued that there are four stages of escalation with the fourth and final stage exhibiting unrestrained use of violence against opponents.

In the Sri Lankan case at the beginning of independence we see a state that is relatively plural. The two major ethnic groups tended to be autonomous organizations based on ethnic, religious and geographic separation but there were cross membership ties such as the Christian Church and English-speaking schools for the political elite. Aside from these two institutions there were also examples of social and economic links across the two communities. Social control at the time was firmly planted within the political elite who still showed faith in the political process to resolve their differences. There was also support from both communal groups for a unitary state as envisioned by the Soulbury Commissioners. In 1956 there was evidence of a shift in the degree of social control. In an effort to appropriate Sinhalese cultural values, the Bandaranaike regime abandoned the western values that had been implanted within the political structure, such as protection for the minorities within the constitution, and sought to draw on the immense reserve of social control that could be obtained by appealing to linguistic nationalism. With the passing of language legislation and educational reform, the state, in its effort to secure social control, appealed to the rising cultural awareness of the Sinhalese and blatantly violated the rights of the Tamils. Faced with the choice of assimilation or countermobilization of ethnic nationalism the Tamil community chose the latter. The consequent mobilization of Tamil nationalism had its costs to the government. It meant 
that some of the social control it had shared with other Tamil organizations--such as the Federal Party and Tamil Congress--shifted more to those organizations. This was evident in the increasing demands for political autonomy among Tamil groups. The tension isolated each community and as the political landscape changed from relative pluralism to ethnic nationalism, communal leaders of the ethnic groups were able to exercise more control over the values, aspirations and the sentiments of their constituencies.

Once the population had been mobilized and arranged along ethnic lines the state found it difficult to control Sinhalese hostility towards the Tamils. The state increasingly became outflanked by Sinhalese extremist groups who were able to offer strategies of survival that were more in tune with the heightened cultural awareness. The inability or unwillingness of police to bring the 1958 riots under control was the first indication that the government had released an animal it could not control. By 1977, and the election of JR Jayewardene, the situation had escalated even further beyond the control of the state. With the presidential election and referendum, the state succumbed to the paradox that Migdal describes. By resorting to "dirty tricks" to obtain social control it had undermined the very instruments of social control. The police and security forces were fractionalized and rife with corruption. The judicial system had been subverted and respect for rule of law had disintegrated. Sri Lankan society was extremely fragmented. The Bhikkus and extreme nationalists secured a popular following thereby exercising and sharing a good deal of social control. Unfortunately they had offered a survival strategy that was inimically hostile to Tamil interests. The subsequent riots of 1977 and 1983 revealed an ever decreasing degree of social control emanating from the state. The state 
was unable to control substantial segments of society. In 1983 there are even suggestions that some elements within the state refused to reestablish public order so as to advance their negotiations. This fits the model if one sees the state as deliberately trying to appease Sinhalese interests in order to sustain social control.

The role of the Sinhalese youth groups can also be explained by the model. Rapid population growth had produced a youth that had been tantalized with increased expectations only to have them dashed by shrinking employment opportunities as economic policies failed to create the jobs anticipated. When faced with decreasing opportunities the Sinhalese youth accepted the prevailing ethnic attitude that the problem was with the Tamil community. This perception was underscored by the ever growing belief structure and media bombardment that the Sinhalese were different from the Tamils and the chosen protectors of Sinhalese Buddhism. With the state unable to offer the opportunities desired, the youth turned to radical groups that offered an alternative vision of the future. Efforts to implement that vision began in the 1971 with the JVP insurrection which offered a socialist conception of society coupled with the romantic image of revolutionaries--strong instruments of social control indeed for a disillusioned youth. When the first efforts failed a second opportunity for reform was offered by association with the JSS and its connections to power through individuals like Cyril Mathew.

Within the Tamil community, Tamil moderates by 1983 were faced with intimidation from Sinhalese chauvinism, on the one hand, and terrorist extremists on the other. The consequence was a diminished ability to exercise restraint over events. As we have noted, the TULF in the early 1980 's was led by inexperienced leaders who had 
allowed extremist youth to back them into an unnegotiable corner. Once committed to separatism, intimidation through violence prevented moderate leaders from acting with any degree of authority in bargaining with the government. After being forced out of irrigation scheme settlements or Colombo, the steadily increasing vision and interconnected set of beliefs, coupled with increased opportunity for sheer survival and cultural and filial connections in Jaffna, meant refugees and Tamils residents increasingly came to believe and require an alternative to the survival strategy offered by the Sinhalese dominated state. In the battle to exercise social control over this new organizational structure Tamils felt increasing despair at the inability of the political parties to offer a concrete method to implement the new vision thus they too turned more and more to the Tamil militants.

The model explains many facets of the Sri Lankan crisis. To be sure there are aspects of the Sri Lankan case that would require more in depth fieldwork but the model, does appear to focus our attention on the struggle for social control and help explain state actions, the escalation of conflict and the actions of various groups within Sri Lankan society. Having determined at least a rough fit we can now turn to the second more important task. Does the framework, as much as it is possible to say at this stage, identify some of the relationships that would enable us to better understand some causes of human rights abuse in Sri Lanka? We recall that the first relationship drew our attention to the degree social and economic cleavages are aligned in vertical formation in society and the possibility that a regime may use discrimination to increase its social control and advance its own poli ical goals. This was essentially the precondition for a struggle of social 
control and human rights abuse.

The actions of the Bandaranaike government in 1956 and the formation of Sri Lankan society appear to support this assertion up to a point. It was quite clear that once linguistic nationalism had proven itself to be a potential vote-getter both the SLPF: and the UNP abandoned the broader definition of 'Swabasha' for the narrower confines of Sinhala-only. It is equally clear that the Sinhalese politicians encouraged ethnic and linguistic nationalism as a means of electioneering to increase their support among the Sinhalese majority. What was surprising about the 1956 election was the willingness of Tamil politicians to succumb to the same techniques of fear-mongering to also gain votes. The point where the evidence differs from the expectations was that in the Sri Lankan case it was discriminatory legislation that really created the cleavage in society not the other way around. This is important because it signifies that political elites may have greater ability to create cleavages than previously suspected. The relationship may be changed to suggest that political elites will use discriminatory legislation if there is a potential to align society in vertical formation. The important structural variable therefore depends on the potential formation of society and the ability of political or social elites to manipulate social identity to their advantage.

The second relationship questioned whether the presence of moderates within the government could retard escalation. In the Sri Lankan case at each step of excalation there appeared to be greater ostracization of moderates on both sides of the communal divide. On the Sinhalese side, Howard Wriggins graphically described how moderates in the 1956 election were cowed by feelings of cultural guilt. After 1956, extreme politicized monks 
also had significant impact on the legislatory agendas of the both the UNP and SL.PF governments. The formation of Buddhist priesthood behind S.W.R.D. Bandaranaike helped secure his election and continually dominated the Sri Lanka media. (Singer, 1991, p. 267) For the UNP's part, A. Jeyaratnam Wilson also clearly underlines the role of the Buddhist monks during the latter part of Jayewardene's tenure.

The Buddhist monks enjoyed unlimited power to dictate policy; they will in the end be responsible for the demise of the state. They have no conception of how the affairs of a modern state are managed.(Jeyaratnam Wilson, 1988, p. 214)

Satchi Ponnambalam is much more critical of the role of the Bhikkus to push political agendas to the extremes. He states:

Every village had its local bhikkhu, the religious story-teller, venerated for his knowledge, service to Buddhism and ascetic life. When such men resorted to religious pressure for political purposes, as they did in the 1956 elections to make Sinhala the only official language, all hell was let loose in the country. (Ponnambalam, 1983, p. 97)

On the Tarnil side, the ostracism of moderates was more poignantly demonstrated by the rise of Tamil militant separatists. Each time the Tamil political parties negotiated an agreement only to have it reneged by the government. the moderates lost ground to militants and were forced to reflect increasingly vocal demands for autonomy. Successive riots in Colombo also victimized many of the Tamil moderates which reduced their impact or potential impact on political processes.

Finally in the third set of relationships, we attempted to focus on the struggle for social control at three different levels in order to better understand some factors and 
elements of human rights abuse. it was ventured that with the dispersion of social contrul away from the state, human rights abuse may occur as a result of the struggle between the state and strongmen to exercise greater social control. It was also ventured that if the struggle for social control escalates, with the state losing whatever degree of social control it had previously owned, human rights abuse may also increase. The third set of relationships was based on what was described as three potential levels of human rights abuse. The first level was identified by Migdal as 'dirty tricks'. To counteract either increasing social control within separate parts of the state structure or outside of the stite structure, state elites resort to dirty tricks. Dirty-tricks could involve a variety of strategies including illegal imprisonment and deportation, strange disappearances, torture and death squads. What distinguishes dirty tricks most, is the attempt by state elites to use methods that undermine the very rules needed to secure social control. They are in essence altacks on the state's explicit or implicit rules of the game and its legal code by the leaders of the state themselves. The actions of Sri Lankan governments from 1956 to the present clearly show a propensity to use illegal, or unconstitutional methods for partisan advantage and to extend social control. In the SLPF era dirty tricks included modifying the constitution to bypass minority protection clauses, modification of educational policies that clearly went against fundamental rules of nondiscrimination, and unfair treatment of Estate Tamils. Under the UNP regime from 1977 onwards use of dirty tricks intensified including clearly undemocratic procedures during the presidential elections campaign and the referendum. Intimidation and manipulation of the judiciary which was condemned by Paul Seigart in his report to the ICJ was yat another example. Indeed Seigart states: 
The Constitution [1978] indeed guarantees these things [rule of law] but the effectiveness of those guarantees depends critically on the responsibility, free from all party-political or other considerations, with which the President exercises his powers in this field. Unfortunately, in this resper" President Jayewardene's record has not proved to be entirely free from blemish. (Seigart, 1984, p. 57)

Finally the measures of the Prevention of Terrorism Act which horrified many human rights organizations went far beyond necessity and undermined all trust the Tamils had in the state (1) uphold the rule of law. In all cases the use dirty tricks had the most impact on the Tamils. In terms of social, economic and cultural rights, the language legislation and educational reforms had far reaching consequences for the Tamil community. Statistics on the impact of language and education reform make a telling story. By 1970 Tamil employment in the Ceylon Administrative service had dropped from 30\% to 5\% and Tamil employment in the government clerical services dropped from $50 \%$ to $5 \%$. (Ponnambalam, 1983, p. 174) Similarly educational reform equally sacrificed Tamil interests to appease Sinhalese nationalists. The proportion of Tamil places in disciplines such as engineering fell from $24.4 \%$ in 1974 to $16.3 \%$ in 1975 and from $36.9 \%$ to $25.9 \%$ in the medicine faculty for the same years.

The second level of human rights abuse was attributed to social organizations that had gained significant mobilization and militant capacity and were able to operate outside the rules of law. In an environment where state leaders had lost social control, or had even undermined the rule of law, social organizations that had gained social control were able to pursue their own ruthless path. The actions of the JVP, the Tamil Tigers and the state union - the JSS, all demonstrate the importance of monitoring the actions of militant 
social organizations. Obeyesekere's account of the rise of institutional violence also supports the contention that the JSS, by appealing to the youth, had created a significant power base and had used its militant ranks with little regard for law and order. The accounts of the JSS also support the assertion that it had essentially outflanked the state in securing social control by appealing to a more extremist form of Sinhalese chauvinism. That the JSS was responsible for the death of many Tamils in both the 1981 and the 1983 riots has not been proven conclusively but the evidence compiled by both Obeyesekere and Virginia Leary present convincing arguments. Equally clear was the ability of the Tamil Tigers and other insurgent groups tn use violence and intimidation to achieve their goals. The record of human rights abuses on Sinhalese settlers and Tamil moderates are also well documented by Amnesty International.

Finally the third potential level of human rights abuse also stands up well in the Sri Lankan study. The assertion held that pressure from other social groups on local 2dministrators would reflect the battle for social control at the top political levels. This would be especially true for military commanders and security personnel in the Jaffna area. Isolated from their families and facing a hostile Tamil community they would have had to rely extensively on the belief structure from the prevailing social order which also held that their purpose in the Jaffna peninsula was to subdue a renegade community that threatened to destroy the land, language and faith of their island. When subjected to these pressures, potential death and hostility from Tamils they easily rebelled and resorted to methods that went against human rights principles. Since the state in the late 1970's and early $80^{\prime}$ 's was itself losing social control and resorting to extra legal methods it had little 
capacity, mobilization, or basis to ensure that military commanders or the rank and file paid attention to human rights norms. Coupled with the far reaching guidelines of the PTA, military personnel were also given immense latitude to act in whatever way they chose.

At the beginning of this project I emphasized that the Sri Lankan study was a preliminary effort to test the framework. It is not a fully testable model and will not yet meet the stringent requirements of a theory. To fully test the model more work is required to understand the dynamics of social control especially in regards to the transfer of social control away from the state to other social organizations. Gleaning fragments of information from second sources and a degree of speculative argument suggests that the model deserves further testing. Evidently there is a need to field test the model and address questions on how, for example, an organization like the JSS or the Tigers (in their early struggle) sustain social control since as a nonstate organizations they had little capacity to distribute resources. The evidence suggests the opportunity to release frustration against perceived opponents is s.fficient. More research is also needed on the dispositional variables to understand more about the decision-making process among state elites and the recourse to discriminatory legislation or dirty tricks. More understanding is also required on the awareness of state elites to the dispersion of social control. The withdrawal of Sirimavo Bandaranaike, her complete surprise at strength of the JVP insurrection and the isolation of President Jayewardene from day-to-day events suggests 
that they may not have been aware that they were losing social control." Indeed if this is the case it would refute certain crucial assumptions of Migdal that state elites are constantly aware of potential threats to their social control.

Further testing is also required on the role other cleavages play in contributing to human rights abuse. This framework has concentrated on ethnic cleavages but there are many other forms of social cleavage such as class, urban/rural, religion and ideology that could be incorporated into the framework. Obviously the impact of other forms of cleavage may differ from the impact of ethnicity and would have to be tested especially to determine possible commonalities in the behaviour of social organizations.

The potential impact of further successful testing of the model in terms of the promotion of human rights also presents some interesting dilemmas. On the one hand it suggests increased effort at training security forces is required so that local commanders are able to resist pressure from social organizations and maintain continued respect for human rights principles in spite of the struggle of social control that may be occurring at other levels of state. The dilemma for human rights organizations lies in the possible association with military or security forces, something they have been loathe to do in the past for fear of compromising their objectivity.

There is a more serious dilemma for aid organizations. In the event of a fragmentation of social control among social groups and the state, aid organizations may have to decide which group should be assisted. For government aid organizations, such

\footnotetext{
${ }^{23} \mathrm{~A}$. Jeyaratnan Wilson (1988) in his book The Breakup of Sri Lanka. describes the seclusion of President Jayewardene during the negotiations with TULF over the District Development Councils. Wilson describes a series of occurrences where Jayewardene was either misled by advisors or treated as superfluous by some who derubed that, given his age, he would remain on the political scene for long.
} 
as the Canadian International Development Agency, this ultimately would require a political assessment that flies in the face of traditional anxieties about intervention and sovereignty. In the past, government aid organizations have tended to rely on bilateral channels to aid recipient governments while Non Governmental Organizations (NGOs) have focused their energies on social organizations. In an environment of social conflict obviously these traditional partnerships may only exacerbate the struggle for social control by embroiling outside donor groups. ${ }^{24}$ One possible averiue out of this dilemma is to fund coalitions of state and nonstate organizations. This would recognize the dispersion of social control within recipient countries and assist in the formation of moderate groups able to bridge the gulf.

CIDA's Philippine Canadian Human Resource Development Program is one example of a program that attempts to build bridges between competing social organizations. Following President Ferdinand Marcos' deposement in 1986 the Negros Island was one of the provinces most devastated by Marcos cronies. The Philippine sugar industry centred in the province had suffered from both a 15-year low in prices and from forced sales to Marcos-backed sugar companies. Hundreds of thousands of workers were jobless, more than half of the job force, and nearly 80 per cent of the island's population was on the verge of starvation. In 1986 Canada was also in the process of launching new aid initiatives. One of the initiatives became known as the Philippine Development Assistance Program(PDAP). Basically the program was intended to enable a coalition of Philippine NGOs to receive funding from Canada to implement a series of projects. The

\footnotetext{
${ }^{34}$ Again nefer w the discussion by David Gillies (1989) on the troubles encountered by CIDA in the Mahweli Sthemc in Sri Lanka.
} 
upshot of both changes in sugar prices and Canadian naivete however was the domination of the coalition by members of the Philippine landowning elite which made a laughing stock of C.iDA's aim to promote land reform and economic restructuring in the N-aros Island. The Canadian public became alarmed that Canada was in essence supporting landowners who were in turn using private vigilante armies to conduct a "low intensity conflict" against Communists (who threatened the hacienda system) and committing innumerable human rights abuses of peasants in the process. (Laurie, 1988: Wurfel, 1989) When CIDA came under public criticism it launched a series of consultations and restructured the PDAP coalition, including forcing the resignation of some landowners and insisting that any new projects had to contain at least one element of permanent land reform with the transfer of land titles to farmers or farmer's co-operatives. The most innovative and constructive response of the Philippine program to the criticism, according to David Wurfel, was the creation of an entirely new structure called the PCHRD (Philippine Canada Human Resources Development). The PCHRD, said Wurfel, was "unique" both in the Philippine experience with foreign aid donors and in the history of CIDA. The program went farther to build bridges over conflict that anything CIDA had done to date. The ten Philippine NGOs on the Philippine coordinating committee bridged the complete ideological spectrum ranging from the Philippine Business for Social Progress on the 'Right' end of the scale to the NCPD (National Council for People's Development) on the 'Left' end. A Canadian coordinating committee of wide membership was also formed and together with the Philippine NGOs made up a joint steering committee which was authorized to approve projects up to $\$ 2(x),(x)$. CIDA made 
available $\$ 15$ million over five years. Again according to Wurfel, CIDA had provided a venue for fruitful dialogue among Philippino NGOs which had never before met and had previously viewed each other with suspicion, thus strengthening the hand of moderates on both the left and right. He concludes:

Insofar as PCHRD can sustain dialogue across the political spectrum and can promote development with justice, while protecting the human rights which must be exercised in the process, it will have made some contribution to conflict resolution and the promotion of peace in a land which has certainly enjoyed too little of it in recent years. (Wurfel, 1989, p. 26)

Clearly the PCHRD program raises a host of questions that cannot be answered here, but the intent of mentioning the PCHRD program is to give an example of how aid programs can, if properly constructed, cut across social cleavages and begin to at least address conflicts that contribute to human rights atuse.

Aid organizations like CIDA in employing a coalition approach such as the PCHRD program, have demonstrated at least some capacity to use innovative ways to cope with conflict in the Third World. A lot of work obviously remains be done and one crucial element of the international development agenda is to continue trying to understand human rights abuse in order to further the exploration of ways to avoid creating human rights victims. The central argument of this paper has been that we must look beyond states and psychopathic regimes to the very social fabric and make up of

\footnotetext{
'For a further discussion of the PCHRD program please see David Wurfel. (1989). Canadian Aid. Sucial Change and Political Conflict in the Philippines - Prospects for Conflict Resolution: Paper presented ts the Aid as Puakemaker Seminar. Parliamentary Centre for Foreign Aftairs and Foreign Trade, Otawa, Nov. 27-26, 1989. Also wiec Peter Lauric. (198X) Canadian Aid. Keeping the Peasants Down. Who's Our Money Working For In The Philippints. This Magavins. Ocuber 198*.
} 
society if we are to truly understand human rights abuse. This thesis has attempted to provide a analytical framework model to enable us to focus on some relationships and factors that may contribute to human rights abuse. The size and complexity of these issues precludes easy answers, conclusive arguments or exhaustive frameworks but they are questions that collectively we have a responsibility to examine. 


\section{BIBLIOGRAPHY}

\section{SOCIAI. CONFLICT AND STATE TERRORISM}

Azar, E. (199)), The Management of Protracted Social Conflict: Theory and Cases, Brookfield, Vermont, Gower.

Duvall, R. \& Stohl, M., (1988), Governance by Terror. In M. Stohl (Ed.), The Politics of Terrorism, (pp 231-271) (3rd edition), New York, Marcel Decker Inc.

Eckstein, H., (1980), Theoretical Approaches to Explaining Collective Political Violence, in T.R. Gurr (Ed.), Handbook on Political Conflict: Theory and Research, (pp 135-166) New York, New York Free Press.

Gurr, T.R. (Ed,), (1980), Handbook of Political Conflict: Theory and Research, New York, New York Free Press.

Gurr T.R., (1986a), The Political Origins of State Violence and Terror: A Theoretical Analysis., In M. Stohl \& G. A. Lopez (Eds.), Government Violence and Repression, An Agenda for Research, (pp. 45-71) Westport, Conn., Greenwood Press.

Gurr, T.R., (1986b), Persisting Patterns of Repression and Rebellion: Foundations for a General Theory of Political Coercion. In M. P. Karns (Ed.), Persisting Patterns and Emergent Structures in Waning Centuries, (pp. 149-168), New York, Praeger.

Harff B. \& Gurr, T.R. (1987), Towards an Empirical Theory of Genocides and Politicides. Identification of Cases since 1945, Conference Paper Presented at the Washington DC Annual Convention of the International Studies Association

Harff B. (1986), Genocide as State Terrorism. In M. Stohl \& G. A. Lopez Government Violence and Repression. An Agenda for Research, (pp. 165-187) Westport, Conn Greenwood Press

International Alert, (1987) Uganda, International Seminar on Internal Conflict' Institute of Social Research, Makerere University, Kampala.

International Alert. (1989), International Programme on Internal Conflict in Uganda, 19871989. International Peace Research Institute, Oslo,

Kriesberg. L. (1982). Social Conflicts, (2nd Ed) Englewood Cliffs, N.J., Prentice-Hall Inc. 
Lopez, G. A. (1984), A Scheme for the Analysis of Government as Terrorist. in M. Stohl \& G. A. Lopez, The State as Terrorist: The Dynamics of Governmental Violence and Repression. (pp. 59-81) Westport, Conn., Greenwood Press.

McCamant, J., (1984), Governance Without Blood: Social Science's Antiseptic View of Rule, or, The Neglect of Political Repression, In M. Stohl \& G. A. Lopez. (Eds). The State as Terrorist. The Dynamics of Governmental Violence and Repression.(pp. 8-27) Westport, Conn. Greenwood Press,

Nicolson, M., (1984), Conceptual Problems of Studying State Terrorism in M. Stohl \& G. A. Lopez The State as Terrorist: The Dynamics of Governmental Violence and Repression, (pp. 27-44) Westport, Conn. Greenwood Press.

Schmid A. P. et. al. (1988), Political Terrorism, A Guide to Actors, Authors, Concepts, Data Bases. Theorıes and Literature, Amsterdam, North Holland Publishing Co.

Schmid, A. P. (1989) Research on Gross Human Rights Violations: A Programme The Center for the Stuay of Social Conflicts, Leiden. The Netherlands.

Stohl M. (Ed) (1988) The Politics of Terrorism, (3rd Ed), New York, Marcel Decker Inc.

Stohl M. \& Lopez G.A. (Eds). (1984). The State as Terrorist: The Dynamics of Governmental Viulence and Repaession. Westport, Conn. Greenwood Press.

Walter, E.V. (1969), Terror and Resistance: A Study of Political Violence, London, Oxford University Press.

Zimmermann, E. (1980), Macro Comparative Research on Political Protest, In T.R. Gurr (ed), Handbook on Political Conflict: Theory and Research. (pp. 167-237) New York. New York Free Press.

Zimmermann, E. (1983) Political Violence, Crises and Revolutions. Theories and Research, Cambridge Mass., Schenkman Publishing Co.

\section{ETHNICITY}

Brass P.. (Ed) (1985). Ethnic Groups and the State, (pp. 1-56) London, Croom Helms.

Brown, D. (1989) Ethnic revival: Perpsectives on State and Society, Third World Quarterly, Vol. 11, No. 4 1-17

Essman, M. (1987). Ethnic Politics and Economic Power, Comparative Politics Vol. 19. No 4, 395-418 
Essman, M. (199()), Economic performance and Ethnic Conflict, In J. Montville, (Ed) Conflict and Peacemaking in Multiethnic Societies, (pp.477-491) Lexington Mass., Lexington Books.

Geertz, C. (1963). The Integrative Revolution, Primordial Sentiments and Civil politics in the New States, in E. Geertz, (Ed.) Old Societies and New States, the Ouest for Modernity in Asia and Africa, (pp. 105-157) New York, The Free Press.

Glazer N. \& Moynihan D., (Eds) (1975) Ethnicity: Theory and Experience, Cambridge M.A. Harvard University Press.

Horowitz. D. (1985). Ethnic Groups in Conflict, Berkeley, University of California Press.

Horowitz, D., (199()). Making Moderation Pay: The Comparative Politics of Ethnic Management for Policy Makers, In J. Montville (Ed). Conflict and Peacemaking in Mutiethnic Societies, (pp.451-477). Lexington, Mass., Lexington Books.

Nnoli, O. (1978) Ethnic Politics in Nigeria, Enugu, Nigeria, Fourth Dimension.

Rupesinghe, K., (1987) Theories of Conflict Resolution and Their Applicability to Protracted Ethnic Conflicts, [Special Issue] Bulletin of Peace Proposals, Vol. 4

Ranaan, U., (Ed) (1980) Ethnic Resurgence in Modem Democratic States, (pp. 1-29) New York, Pergamon Press 1980

Stavenhagen, R., (1987). Ethnic Conflict and Human Rights Their Interrelationship, in K. Rupensinghe (Ed) [Special Issuel Bulletin of Peace Proposals, Vol. 4 17-25

Volkan, V., (1990) The Pyschoanalytical Aspects of Ethnic Conflicts, in J. Montville, Conflict and Peacemaking in Multiethnic Societies (pp. 81-93) Lexington Mass., Lexington Books.

\section{HUMAN RIGHTS}

De Kadt, E. (1980) Some Questions on Human Rights and Development, World Development, Vol. 81980

Donnelly, J., (1982) Human Rights and Foreign Policy, World Politics, Vol.34, (July 1982), 574-571

Donnelly. J.. (1982) Human Rights and Human Dignity: An Analytic Critique of NonWestern Conceptions of Human Rights, The American Political Science Review, Vol. 
76 (June 1982) 303-316

Donnelly, J. (1988) Human Rights: The Impact of International Action. International Journal, Vol. 28 (Spring 1988) 241-263

Donnelly, J. \& Howard R., (1986) Human Dignity, Human Rights, and Political Regimes. American Political Science Review, Vol 80, No. 3 (Sept. 1986) 812-817

Donnelly. J. \& Howard, R. (Eds), (1987) International Handbook of Human Rights. New York, Greenwood Press.

Donnelly, J. \& Howard R. (1988) Assessing National Human Rights Performance: A Theoretical Framework, Human Rights Quarterly. Vol. 10, 215-248

Forsythe, D., (1991). The Internationalization of Human Rights, Lexington Mass., Lexington Books 1991

Gillies, D. (1990) Evaluating National Human Rights Performance: Priorities for the Developing World, Bulletin of Peace Proposals, Vol 21(1), 15-27

Gillies, D. (1988) On an Equal Footing? The Integration of Human Rights in Canadian Foreign Policy, Centre for Developing Area Studies, McGill University, 1988

Gillies D., (1989) Principled Intervention: Canadian Aid, Human Rights and the Sri Lankan conflict, Paper presented to the Aid As Peacemaker Seminar, Parliamentary Centre for Foreign Affairs and Foreign Trade, Ottawa, Nov. 27-28, 1989

Howard, R. (1983). The Full-Belly Thesis: Should Economic Rights Take Priority Over Civil and Political Rights? Evidence from Sub-Saharan Africa, Human Rights Quanterly, Vol. 5 467-490

North/South Institute, (1988) Human Rights - Canadian Foreign Policy Toward Developing Countries," Briefing Paper, Dec. 1988

Leary V. \& Welch, C., (Eds), (1985) Asian Perspectives on Human Rights, Boulder. Westview Press.

O'Manique, J. (1990) Universal and Inalienable Rights: A Search for Foundations," Human Rights Quarterly, Vol. 12 (Nov. 1990) 465-485

O’Manique, J., (in press) Development, Human Rights and Law, Human Rights Quarterly.

Pollis, A. \& Schwab, P. (Eds.). (1979). Human Rights, Cultural and Ideological Perspectives, New York, Praeger Publishers 
Pollis, A. \& Schwab, P. (Eds.). (1982) Toward a Human Rights Framework, New York, Praeger Publishers, Praeger Special Studies

Rudner, M., (1983) Human Rights Conditionality and Development Assistance' Study Prepared for the Canadian International Development Agency, January 1983

Stohl, M., Carleton, D., Lopez, G., Samuels, S., (1986). Violations of Human Rights: Issues and Problems of Measurement. Human Rights Ouarerly Vol 8 No. 4, 592-602

\section{(ALNERAL,}

Coser, L., (1982) The Notion of Control in Sociological Theory, In J. Gibbs, Social Control, Views from the Social Sciences, (pp. 19-22) London, Sage Publications

Genth H.H. \& Mills C. W. (Eds). (1946 From Max Weber: Essays in Sociology. New York, Oxford University Press

Huntington, S.. (1971) The Change to Change: Modernization, Development and Politics, Comparative Politics II (April 1971) 283-322

Janis, I. (1982). Groupthink, Pyschological Studies of Policy Decisions and Fiascoes, Boston, Houghton Mifflin Co.

Laurie. P., (1988) Canadian Aid, Keeping the Peasants Down, Who's Our Money Working For In The Philippines, This Magazine, October 1988. 23-29

Lebow, N., (1981) Between Peace and War. The Nature of International Crisis, Baltimore, John Hopkins U. Press

Mayer, J., (1983). Notes Towards a Working Definition of Social Control in Historial Analysis, in S. Cohen \& A. Saill, (Eds) Social Control and The State, (pp.17-33) New York, St Martins Press

Mazrui. A. \& Tidy, M., (1984). Nationalism and New States in Africa, London, Heinemann International

Migdal, J. (1988) Strong Societies and Weak States, State Society Relations and State Capabilities in the Third World, New Jersey, Princeton U Press.

United Nations Development Program, (1991) Human Development Report 1991, New York, Oxford University Press. 
Weber, M. (1964) In T. Parsons (Ed) The Theory of Social and Economic Organization. Toronto, Collier-Macmillan Ltd.

Wurfel, D., (1989) Canadian Aid, Social Change and Political Conflict in the Philippines Prospects or Conflict Resolution: Paper presented to the Aid as Peacemaker Seminar. Parliamentary Centre for Foreign Affairs and Foreign Trade, Ottawa, Nov. 27-28, 1989.

\section{SRI LANKA}

Amnesty International, (1982) Summary of Report on a Mission to Sri Lanka, 31 Jan.9 Feb. 1982

Amnesty International (1983) Statement updating its Human Rights Concerns in Sri Lanka, July-Sept 1983, Sept. 1983

Amnesty International (1984) Sri Lanka: Current Human Rights Concerns and Evidence of Extra Judicial Killings by the Security Forces, July 1983 - April 1984

De Silva, C. R. (1978) The Impact of Nationalism on Education: the Schools Takeover (1961) and the University Admissions Crisis, 1970-1975, In Michael Roberts, Collective Identities, Nationalism and Protest in Sri Lanka during the Modern Era. (pp 475-499) Colombo, Marga Institute.

De Silva, C.R., (1979) The Constitution of the Second Republic of Sri Lanka (1978) and its Significance. Journal of Commonwealth and Comparative Politics, XVII (2), (July 1979), 192-210

De Silva, C. R. (1984) Plebiscitary Democracy or Creeping Authoritarianism? The Presidential Election and Referendum of 1982, In J. Manor, (Ed) Sri Lanka in Change and Crisis,(pp.35-51), London, Croom Helm Ltd.

De Silva, K. M. (1986) Managing Ethnic Tensions in Multi-Ethnic Societies, Sri Lanka, 1880-1985, London, University Press of America.

De Silva, K. M., (1976) Discrimination in Sri Lanka. In W.A. Veenhoven (ed) Case Studies on Human Rights and Fundamental Freedoms: A World Survey. Vol 3, The Hague, Published for the Foundation for The Study of Plural Socieites, 1976 73-116

Canadian International Development Agency, Canadian Development Cooperation in Asia, Asia Branch, June 1990

Fernando, T., (1973). Elite Politics in the New States. The Case of post independence Sri Lanka, Pacific Affairs, XLVI (3) Fall 1973, 361-384 
Gunatilleke, G., Tiruchelvam N., and Coomaraswamy, R., (1983) Violence and Development in Sri Lanka: Conceptual Issues, In G Guntailleke et al (Eds) Ethical Dilemmas of Development in Asia, Marga Institute, Lexington Mdss., Lexington Books.

Immigration and Refugee Board Documentation Centre, Sri Lanka: A Country Profile, November 1988, Ottawa

Immigration and Refugee Board Docunentation Centre, Overview on Sri Lanka, no date. Ottawa

Immigration and Refugee Board Documentation Centre, Sri Lanka: An Update, April 1991, Ottawa

Jeyaratnam Wilson, A. (1982) Sri Lanka and its Future: Sinhalese versus Tamils, in Jeyaratnam Wilson \& D. Dalton, (Eds) The States of South Asia, Problems of National Integration, (pp.295-313) London, University of Hawaii Press.

Jeyaratnam Wilson, A. (1988). The Breakup of Sri Lanka, The Sinhalese-Tamil Conflict. London, C. Hurst and Co.

Kearney, R. N., (1964) Sinahalese Nationalism and Social Conflict in Ceylon,' Pacific Affairs, XXXVII, 125-136

Kearney, R. N., (1975) Educational Expansion and Political Volatility in Sri Lanka, Asian Survey, Vol 15 No. 9 (Sept. 1975) 727-744

Keamey, R. N., (1978). Democracy and the Stresses of Modernization in Sri Lanka, Journal of South Asian and Middle Eastern Studies Vol. 1 No. 3 (Spring 1978), 87-98

Kearney, R. N. (1978) Nationalism, Modernization and Political Mobilisation in a Plural Society, In Michael Roberts, Collective Indentities, Nationalism and Protest in Sri Lanka during the Modern Era, (pp.441-461) Colombo, Marga Institute.

Kearney, R. N., (1985). Ethnic Conflict and the Tamil Separatist Movement in Sri Lanka, Asian Survey. Vol 25 No. 9, (Sept. 1985), 898-917

Leary. V. A. (1981) Ethnic Conflict and Violence in Sri Lanka, International Commisssion of Jurists Report, Geneva,

Manor, J. (1979). The Failure of Political Integration in Sri Lanka, Journal of Comparative and Commonwealth Politics, Vol 17(1) $25,21-46$

Manor. J.. (1984) Sri Lanka in Change a:d Crisis, London, Croom Helm Inc. 
Meyer, E., (1984) Seeking the Roots of the Tragedy, in J. Manor, (Ed) Sri Lanka in Change and Crisis, (pp.137-153) London, Croom Helm Inc.

Murray, N., (1984) The State Against the Tamils, Race and Class, A Journal for Black and Third World Liberation, Vol.26 No.1 (Summer 1984) 97-111

O'Ballance, E., (1989). The Cyanide War, The Tamil Insurrection in Sri Lanka, 1973-88. London, Brassey's (U.K.) Pergamon Publishing Corp.

Obeveskere, G., (1984). The Origins and Institutionalism of Political Violence. In J. $M$.no: (Ed) Sri Lanka in Change and Crisis, (pp. 153-175) London, Croom Helm Inc.

Pfaffenberger, B., (1990) Ethnic Conflict and Youth Insurgency in Sri Lanka: The Social Origins of Tamil Separatism, in J. Montville (Ed) Conflict and Peacemaking in Mutiethnic Socicties,(p.241-259) Lexington, Mass., Lexington Books.

Ponnambalam, S., (1983) Sri Lanka, The National Ouestion and the Tamil Liberation Struggle, London, Zed Books.

Roberts, M., (1978) Collective Identities, Nationalism and Protest in Sri Lanka during the Modern Era, Colombo, Marga Institute.

Russell, J., (1978) Sri Lanka's Election Turning Point (The General Election of 1977. Journal of Commonwealth and Comparative Politics XVI (1) (March 1978) 79-98

Sabaratnam, L., (1987) The Boundaries of the State and the State of Ethnic Boundaries: Sinhala-Tamil Relations in Sri Lankan History, Ethnic and Racial Studies, Vol 10, No. 3 (July 1987) 290-310

Samarakone, P., (1984) The Conduct of the Referendum, In J. Manor, (Eo) Sri Lanka in Change and Crisis,(pp. 84-118) London, Croom Helm Inc.

Samarasinghe, S.W.D. de A. (1984). Sri Lanka in 1983, Ethnic Conflict and the Search for Solutions, Asian Survey, Vol. 24, No. 2 (Feb. 1984) 25()-256

Siegart, P., (1984) Sr Lanka - A Mounting Tragedy of Errors, International Commission of Jurists Report, Geneva,

Singer, M., (1990). Prospects for Conflict Management in the Sri Lankan Ethnic Crisis, in J. Montville (Ed) Conflict and Peacemaking in Multiethnic Societies, Lexington, Mass. Lexington Books. 
Sivanandan, A., (1984) Sri Lanka: Racism and the Politics of Underdevelopment, Race and Class, A Journal for Black and Third World Liberation, Vol.26 No. 1 (Summer 1984) $1-39$

Sivathamby, K., (1987) The Sri Lankan - Tamil Question, Socio-Economic and Ideological Issues, Bulletin of Peace Proposals, Vol 4, 133-147

Schwarz, W. (1986) The Tamils of Sri Lanka, London, Minority Rights Group Report, 1986

Spaeth, A., (1991) Inventing an Ethnic Rivalry, Harper's Magazine Nov. 1991, 67-74, 7578

Stirrat, L., (1984) The Riots and the Roman Catholic Church in Historical Perspective, In J. Manor, (Ed). Sri Lanka in Change and Crisis, (pp. 196-214) London, Croom Helm Inc.

Warnapala, W., (1980) Sri Lanka 1979: New Stresses in the Economy and the Polity, Asian Survey, Vol. 20, No. 2 (Feb. 1980) 206-216

Warnapala, W., Parliamentary Government or One Party Dictatorship? The Case of Sri Lanka, India Quarterly, Vol. 38, No. $3 \& 4$ (July/Dec. 1982) 267-288

Wriggins, H., (1960) Ceylon: Dilemmas of a New Nation, Princeton, N. J., Princeton University Press. 

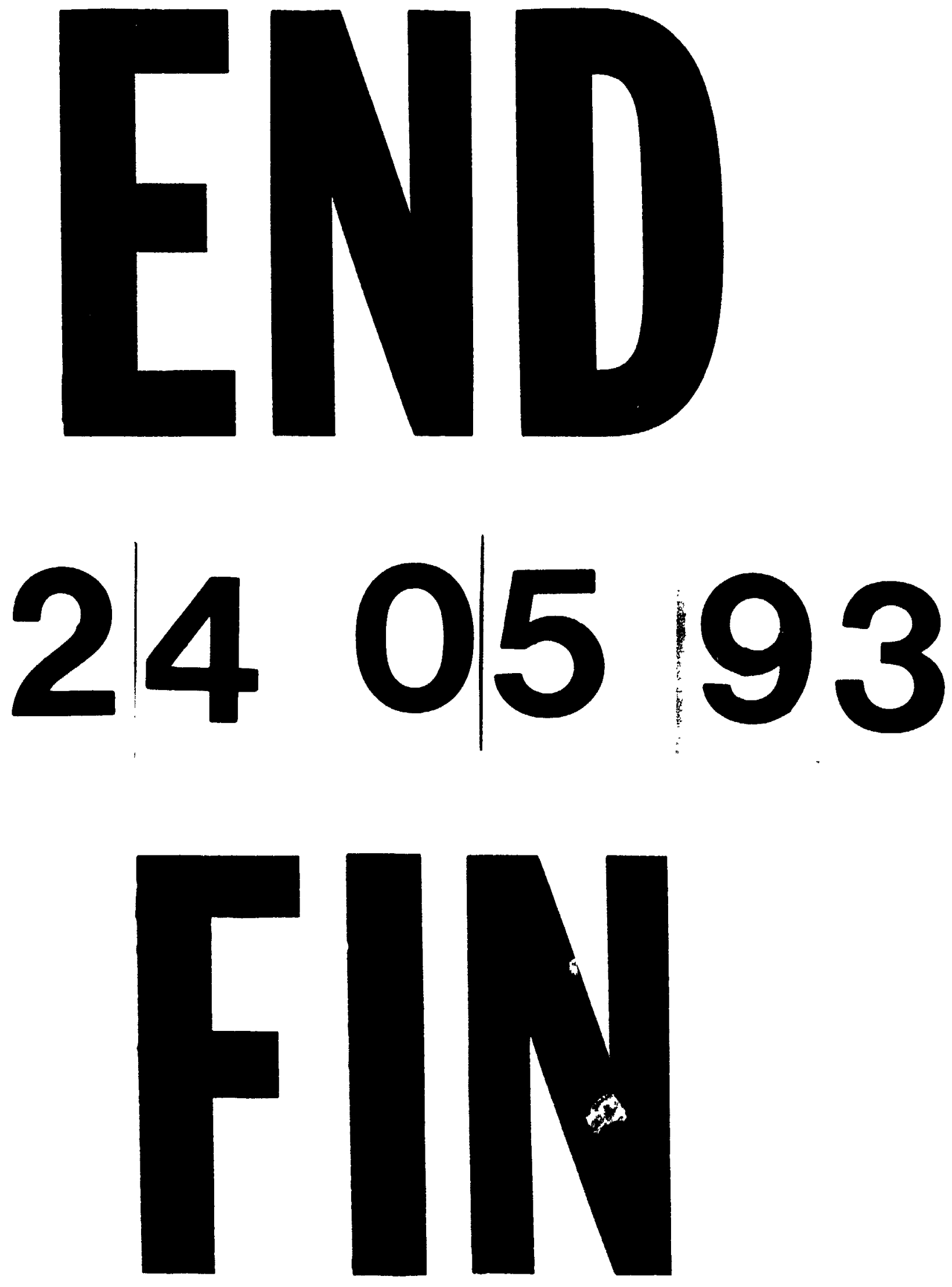